\title{
SAÚDE MATERNO-INFANTIL: VERTENTES À ASSISTÊNCIA ESPECIALIZADA DE ENFERMAGEM
}

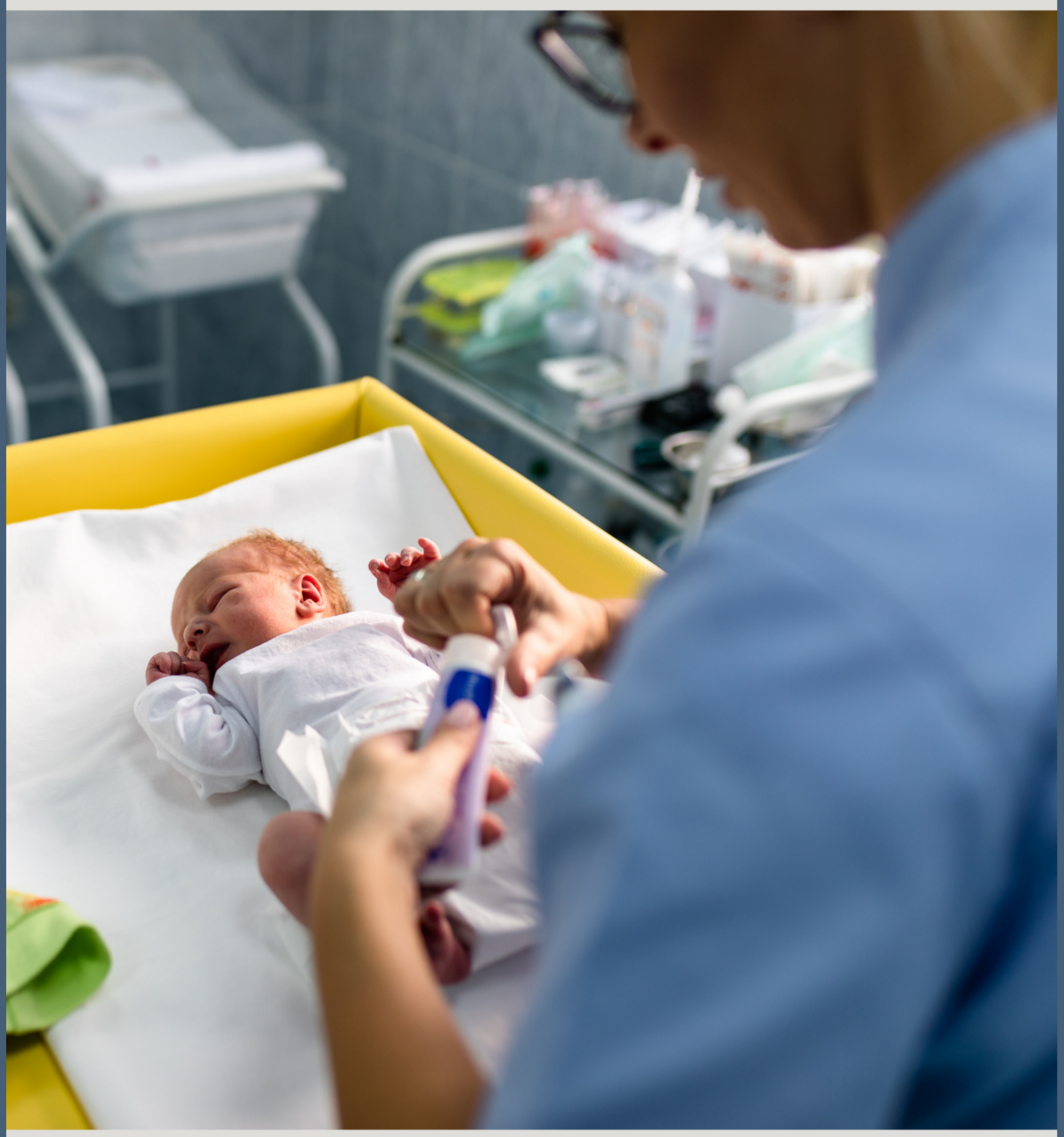

Eliana Amaro de Carvalho Caldeira Raquel de Oliveira Martins Fernandes Laércio Deleon de Melo

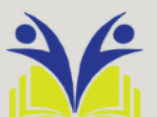


Eliana Amaro de Carvalho Caldeira

Raquel de Oliveira Martins Fernandes

Laércio Deleon de Melo

Saúde Materno-Infantil: Vertentes à Assistência Especializada de Enfermagem

$1^{\text {a }}$ ed.

Piracanjuba-GO

Editora Conhecimento Livre

Piracanjuba-GO 
$1^{\mathrm{a}} \mathrm{ed}$

\section{Dados Internacionais de Catalogação na Publicação (CIP)}

Caldeira, Eliana Amaro de Carvalho

C146S Saúde Materno-Infantil: Vertentes à Assistência Especializada de Enfermagem

/ Eliana Amaro de Carvalho Caldeira. Raquel de Oliveira Martins Fernandes. Laércio Deleon de Melo. - Piracanjuba-GO

Editora Conhecimento Livre, 2021

99 f.: il

DOI: $10.37423 / 2021$.edcl 352

ISBN: 978-65-5367-017-4

Modo de acesso: World Wide Web

Incluir Bibliografia

1. enfermagem-materno-infantil 2. trabalho-de-parto 3. período-pós-parto 4. aleitamento-materno I.

Caldeira, Eliana Amaro de Carvalho II. Fernandes, Raquel de Oliveira Martins III. Melo, Laércio

Deleon de IV. Título

CDU: 613

https://doi.org/10.37423/2021.edc1352

O conteúdo dos artigos e sua correção ortográfica são de responsabilidade exclusiva dos seus respectivos autores. 


\title{
EDITORA CONHECIMENTO LIVRE
}

\section{Corpo Editorial}

\author{
Dr. João Luís Ribeiro Ulhôa \\ Dra. Eyde Cristianne Saraiva-Bonatto \\ MSc. Frederico Celestino Barbosa \\ MSc. Carlos Eduardo de Oliveira Gontijo \\ MSc. Plínio Ferreira Pires
}




\section{SUMÁRIO}

CAPÍTULO 1 6 ASSISTÊNCIA DE ENFERMAGEM HUMANIZADA À PARTURIENTE DURANTE O TRABALHO DE PARTO

Bruna Valladares Locasso Cardoso Jean Gomes

Mirian Nunes

Patrícia Guedes Duarte Sant'Anna

Eliana Amaro de Carvalho Caldeira

Raquel de Oliveira Martins Fernandes

Laércio Deleon de Melo

Leone Mendes Dias

Camila Cristina Gregório de Assis

Juliana de Lima Brandão

DOI 10.37423/211205092

CAPÍTULO 2

ASSISTÊNCIA HUMANIZADA DE ENFERMAGEM DIRECIONADA À GESTANTE E AS

VANTAGENS SOBRE A CESARIANA

Diulle Ellen da Silva Santos

Eliana Amaro de Carvalho Caldeira

Raquel de Oliveira Martins Fernandes

Laércio Deleon de Melo

Leone Mendes Dias

Camila Cristina Gregório de Assis

Juliana de Lima Brandão

Thaís Vidal de Oliveira

Felipe Eduardo Taroco

Josilene Sobreira Rodrigues

DOI 10.37423/211205093

CAPÍTULO 3

CONTRIBUIÇÕES DA ENFERMAGEM NA AMAMENTAÇÃO NA PRIMEIRA HORA DE VIDA DO RECÉM-NASCIDO

Camila do Carmo Vale

Isabel de Fátima Cruz Silva

Renata Rabelo Rodrigues

Thais Sales de Paula

Raquel de Oliveira Martins Fernandes

Laércio Deleon de Melo

Eliana Amaro de Carvalho Caldeira

Maiara Luci Silva Costa

Lara de Oliveira Loures

Camila Cristina Gregório de Assis

DOI 10.37423/211205094 
CAPÍTULO 4

ASSISTÊNCIA DE ENFERMAGEM NA AMAMENTAÇÃO EXCLUSIVA DURANTE O PUERPÉRIO

IMEDIATO.

Maria Caroline Soares de Souza

Eliana Amaro de Carvalho Caldeira

Raquel de Oliveira Martins Fernandes

Laércio Deleon de Melo

Leone Mendes Dias

Camila Cristina Gregório de Assis

Juliana de Lima Brandão

Yasmin Mendonça Campos

Joana Carvalho Barros

Josilene Sobreira Rodrigues

DOI 10.37423/211205095

CAPÍTULO 5

O PAPEL DA ENFERMAGEM NO CUIDADO PALIATIVO A CRIANÇA COM LEUCEMIA Jessica Aline Raimundo

Mariana de Carvalho Oliveira

Rosemeire da Silva Pereira Gouveia

Tairene Maria Pereira Gomes

Eliana Amaro de Carvalho Caldeira

Raquel de Oliveira Martins Fernandes

Laércio Deleon de Melo

Leone Mendes Dias

Camila Cristina Gregório de Assis

Joana Carvalho Barros

DOI 10.37423/211205096 


\section{Capítulo 1}

\section{ASSISTÊNCIA DE ENFERMAGEM HUMANIZADA À PARTURIENTE DURANTE O TRABALHO DE PARTO}

Bruna Valladares Locasso Cardoso

Jean Gomes

Mirian Nunes

Patrícia Guedes Duarte Sant’Anna

Eliana Amaro de Carvalho Caldeira

Raquel de Oliveira Martins Fernandes

Laércio Deleon de Melo

Leone Mendes Dias

Camila Cristina Gregório de Assis

Juliana de Lima Brandão
Enfermeira Graduada pelo Centro

Universitário Estácio de Juiz de Fora, Brasil.

EnfermeiroGraduadopeloCentroUniversitárioEstácic

Enfermeira Graduada pelo Centro

Universitário Estácio de Juiz de Fora, Brasil

Enfermeira Graduada pelo Centro

Universitário Estácio de Juiz de Fora, Brasil

Enfermeira. Doutoranda em Saúde Coletiva pela Universidade Federal de Juiz de Fora, Brasil.

Enfermeira. Mestre em Enfermagem pela Universidade Federal de Juiz de Fora, Brasil.

Enfermeiro. Doutorando em Enfermagem pela Universidade do Estado do Rio de Janeiro, Brasil.

Enfermeiro. Mestre em Enfermagem pela Universidade Federal de Juiz de Fora, Brasil.

Enfermeira. Mestranda em Enfermagem pela Universidade Federal de Juiz de Fora, Brasil.

Enfermeira. Doutoranda em Enfermagem pela Universidade do Estado do Rio de Janeiro, Brasil. 
Resumo: Introdução: a humanização da assistência de enfermagem, durante a dinâmica do trabalho de parto e parto evidencia a importância da participação ativa da parturiente no processo de nascimento. $O$ enfermeiro obstetra atua na promoção de uma assistência humanizada ao parto, sendo um agente facilitador para um nascimento digno e respeitoso. $O$ estudo objetivou a apresentar as atribuições do enfermeiro obstetra na assistência à parturiente durante o trabalho de parto, parto e nascimento. Para tanto, foi realizada uma pesquisa de revisão bibliográfica, a partir dos descritores em ciências da saúde (DeCS) específicos ao tema proposto: Humanização. Parto Normal. Enfermagem Obstétrica, que foram cruzados entre si pelo booleano "AND" no DeCS. Os critérios de inclusão foram a seleção de artigos publicados em português, em base de dados indexada, nos últimos cinco anos, disponíveis na íntegra, de forma gratuita e relacionados ao tema. Os manuais e protocolos do Ministério da Saúde e documentos legislativos não seguiram o critério temporal, devido a sua importância histórica e legal. Foram eliminados todos os materiais que não atenderam aos critérios de inclusão. Após a seleção dos textos, passou-se a leitura, seguida da análise e escrita do texto científico. Desenvolvimento: a história do parto no Brasil reflete a evolução da sociedade capitalista e a subordinação da mulher no processo parturitivo, que deixou o ambiente privado, intrafamiliar, para o ambiente público hospitalar. Como consequência houve aumento da taxa de cesárea e paralelamente o aumento do óbito materno e perinatal. A proposta de humanização do parto e nascimento pelos enfermeiros obstetras surgiu para auxiliar na redução da mortalidade materna e fetal, assim como reduzir o número de cesarianas. Considerações Finais: conclui-se que o parto humanizado, busca resgatar a fisiologia do nascimento, possibilitando que a mulher tenha uma experiência positiva e sem traumas, assumindo o protagonismo do seu parto e nascimento pautado na promoção da segurança de gestante e do bebê.

Palavras Chave: Humanização. Parto Normal. Enfermagem Obstétrica. 


\section{INTRODUÇÃO}

A assistência do enfermeiro obstetra à parturiente, durante o trabalho de parto e parto pode ser entendida como um auxílio especializado para que a mulher possa compreender o processo parturitivo, como sendo um acontecimento bio-psico-socio-cultural (SENA et al., 2012).

A palavra humanização quando empregada no parto e nascimento possuem o sentido de uma promoção do nascimento com segurança de mãe e filho, a partir de um cuidado qualificado e resolutivo, integral e ético. As políticas e ações para humanizar o parto são um marco histórico, reconhecendo a naturalidade do mesmo, proporcionando recursos físicos e humanos para o favorecimento do parto normal e da autonomia da gestante (BRASIL, 2015).

Vargens (2012) refere que humanizar o trabalho de parto é respeitar o tempo natural do processo. É saber ouvir, acolhimento e sempre incentivar a gestante, além de ter as tecnologias necessárias para a assistência durante o trabalho de parto. O Ministério da Saúde através da Rede Cegonha mostra que a equipe de enfermagem deve priorizar uma assistência integral de acordo com as técnicas de sistematização em enfermagem (BRASIL, 2013).

O Ministério da Saúde admite que a assistência durante o trabalho de parto realizado pelo enfermeiro, contribui para o processo fisiológico do mesmo e com isso traz vantagens a gestante e ao recémnascido, diminuindo os riscos de intercorrências ou complicações. Sendo biológico, o parto terá poucas intervenções, sendo menos invasivo para a gestante e para o bebê. Dentre as ações que pertencem ao enfermeiro compreende, o acompanhamento da parturiente em parto de baixo risco (BRASIL, 2015).

Segundo Balaskas (2015) o parto privilegia a gênese natural sendo um guia ao qual resgata a responsabilidade feminina no nascimento, que por vezes acaba se perdendo por desígnios médicos. A mesma autora descreve ainda que o parto ativo não significa um parto perfeito, mas sim um parto repleto da realidade onde a mulher assume o controle do nascimento de seu bebê com apoio de conhecimentos valiosos de suporte ao nascer.

O presente estudo tem como questão norteadora: como a participação do enfermeiro pode contribuir para uma assistência humanizada durante o trabalho de parto e parto.

Portanto, diante dos dados relatados acima e da importância deste tema, o objetivo desse trabalho é apresentar a assistência do enfermeiro obstetra à parturiente, durante o trabalho de parto e parto. 
O percurso metodológico adotado nesta pesquisa foi de natureza qualitativa, através da revisão bibliográfica, baseando-se em artigos, livros e demais materiais acadêmicos. Foram utilizados descritores específicos ao tema proposto: Humanização. Parto Normal. Enfermagem Obstétrica, que foram cruzados entre si pelo boleano "AND" no DeCS (Descritores em Ciências da Saúde). Os critérios de inclusão seguidos foram em artigos publicados em português, entre os últimos 5 anos, ou seja 2014 a 2019 e que estivessem disponíveis na íntegra e de forma gratuita na base de dados, porém manuais e protocolos de relevância ao tema que foram lançados anteriormente também foram utilizados. Foram excluídos todos os materiais que não atenderam o objetivo do trabalho, que não estavam disponíveis de forma gratuita e em português.

O desenvolvimento foi dividido em três subitens, a saber: Histórico da enfermagem obstétrica no Brasil; A humanização e o parto humanizado; O papel do enfermeiro como agente executor do parto humanizado;

\section{DESENVOLVIMENTO}

\subsection{HISTÓRICO DA ENFERMAGEM OBSTÉTRICA NO BRASIL}

Antigamente o ato de concepção era visto como algo feminino, sem importância, natural que não determinava entendimento apropriado para a pessoa que ajudava, não precisando da assistência médica. Com isso esse papel era atribuído as parteiras que tinha a função de acompanhar e auxiliar desde o início da gestação até o nascimento (WALDOW, 2010).

O parto conhecido como cesárea, vem desde o século XV, porém era realizado em raras exceções, nos casos em que a única forma de retirar o bebê do útero deveria ser por meio da cesárea ou em episódios de casos religiosos, onde a progenitora encontrava-se falecida e o bebê ainda estava vivo no intraútero (ANS, 2008).

No início do século XIX existiu uma migração do lugar onde aconteciam os partos, saindo das residências para os hospitais, continuando o parto normal. Isso ocorreu devido ao acréscimo da procura por assistência médica ao pré-natal e parto em detrimento da fornecida por parteiras e por enfermeiras obstétricas (LEISTER; RIESCO, 2013).

Em 1950 ocorreu um declínio no número de partos normais, por causa do aumento das cesáreas (ANS, 2008). Foi no séc. XX que o Brasil presenciou um estouro no número de cesáreas, mesmo sendo em 
muitos casos desnecessárias, em detrimento do parto normal e de seus benefícios mãe-bebê (BRASIL, 2010).

Os riscos que a concretização indiscriminada e desnecessária de cesáreas, podem vir a trazer para as próximas mães e seus filhos são várias e englobam complicações puerperais, como infecções e abcessos de parede, febre, iatrogenias e acontecimentos neonatais, como dificuldades respiratórias e de imaturidade (ANS, 2008).

Sendo assim, tornou-se necessário resgatar a humanização deste processo que havia se "perdido" em decorrência da medicalização do parto.

\subsection{A HUMANIZAÇÃO E O PARTO HUMANIZADO}

Analisando o significado no dicionário online de português: humanizar, a palavra humanizar de humano, -izar significa tornar-se humano, dar condição humana, ato de humanizar, ser bondoso, acolhedor, acessível, ser comunicativo. (DICIO, 2009-2019). Para Bermejo (2008) tem o significado de colaborar para a enriquecimento da qualidade de vida, com intuito de realizar um ótimo cuidado com os outros.

A humanização do parto é bastante distinta, mas defende um método que respeita as individualidades, colocando as gestantes como protagonistas, respeitando às suas características como cultura, crenças, valores e diversidades de opiniões. Tem sido muito discutida no campo da saúde a realização de uma assistência de enfermagem humanizada durante o trabalho de parto (VEZO; CORONEL; ROSÁRIO, 2013).

A humanização almeja que os profissionais de saúde interajam sobre temas como a violência institucional, práticas sem proeminências científicas inseridas ao processo de parto que tem colocado risco a integridade física e emocionais da gestante (DINIZ, 2005).

Os recursos da saúde como os equipamentos que auxiliam apoiam ao parto normal exemplo bola suíça, banheira, arco de apoio de ferro, um quadro ilustrativo de posições de melhor conforto, além disso estimula a humanização do cuidado, pois proporciona o bem-estar da gestante, com a diminuição de riscos, dando-a o conforto e bem-estar também ao acompanhante, práticas harmônicas ao parto normal (REIS; ZULEICA, 2005).

O enfermeiro ao realizar a assistência de forma humanizada deve ter como objetivo respeitar aos aspectos fisiológicos e sem intervenções desnecessárias, devendo respeitar a identidade social e 
cultural, oferecendo suporte emocional à gestante e seus familiares e garantir seus direitos (DIAS, 2005).

O papel da humanização no parto é de respeitar os desejos da gestante, por ser um momento muito importante tanto para ela como para seus familiares. A equipe deve se adequar em cada momento de seu parto, não apenas realizando técnicas, mas lembrando dos sentimentos das pessoas envolvidas neste momento (VEZO; CORONEL; ROSÁRIO, et al., 2013).

Segundo o Manual Técnico do Ministério da Saúde de Brasília (2006), entende-se por humanização:

A valorização dos diferentes sujeitos implicados no processo de produção de saúde - usuários (as), trabalhadores (as) e gestores (as); fomento da autonomia e protagonismo desses sujeitos; a corresponsabilidade entre eles; o estabelecimento de vínculos solidários e de participação coletiva no processo de gestão; identificação das necessidades sociais de saúde; mudança nos modelos de atenção e gestão; compromisso com a ambiência, melhoria das condições de trabalho e de atendimento (BRASIL, 2006, p.6).

\subsection{O PAPEL DO ENFERMEIRO OBSTETRA COMO AGENTE FACILITADOR PARA O PARTO HUMANIZADO}

Em trabalho realizado por Rocha et al. (2015), os discursos das gestantes, referiam ao amparo recebido por parte da equipe de enfermagem e os demais profissionais foi de grande importância. Pois a assistência realizada por enfermeiros obstetras remete à a valorização da mulher, através do apoio psicológico dirigido à gestante no momento do parto, também por realizar uma boa comunicação e compreender a gestante respeitando seu tempo.

Os enfermeiros possuem grande importância na humanização com as gestantes através da atenção dada durante o trabalho de parto, com esse envolvimento se estabelece laços. Com tudo é possível reconhecer um diferencial na experiência das gestantes quanto ao papel da equipe de enfermagem que é verdadeiramente desempenhado, incluindo dois aspectos essenciais na humanização: acolhimento e vínculo (PINHEIRO; BITTAR, 2013).

É fundamental que a equipe esteja envolvida durante o parto, respeitando o tempo, as vontades, ambições e expectativas de cada gestante, durante todo o processo do parto. Sempre chamando a gestante pelo nome, orientando-a em cada procedimento realizado, e sempre que for possível comunicar a família da gestante todos os procedimentos realizados. São transformações de conduta que devem ser realizadas pela equipe que está auxiliando a gestante (COREN SP, 2010). 
A equipe de enfermagem que acompanha a gestante no parto, deve compreender a grande importância do diálogo em sua prática assistencial, de ouvir a gestante e de reconhecer sua necessidade, respeitando sua história de vida, com seus aspectos sociais, que pode ter grande influência no parto, gerando um vínculo entre a equipe multiprofissional e a gestante (OLIVEIRA, 2015).

A presença do companheiro ou de outra pessoa de escolha da gestante na hora do parto faz ela se sentir mais confortável e confiante. Hoje em dia é direito da gestante ter um acompanhante durante todo o trabalho de parto e pós-parto (COREN SP, 2010).

O papel da humanização da assistência engloba vários focos, dentre eles citamos que a gestante tem o poder sobre seu próprio corpo, trazendo de volta a autonomia e com isso seu parto volta a ser um processo fisiologicamente natural. A gestante precisa ser a protagonista de todo o seu parto, e deve escolher qual é a melhor posição para poder ganhar seu bebê (PINHEIRO; BITTAR, 2013).

\section{CONSIDERAÇÕES FINAIS}

Conclui-se com este trabalho que a humanização no Brasil relacionada ao trabalho de parto vem ocorrendo de forma lenta pois ainda se vê muito o padrão biomédico sendo executado, prevalecendo um grande número de procedimentos invasivos e intervencionistas durante o parto.

Em virtude disso não é proporcionado um atendimento apropriado a gestante, existindo ainda uma grande dificuldade em relação aos profissionais de saúde, no que tange a capacitação, no que refere à humanização do parto, para que este momento tenha a grande importância que deve ter na vida da gestante e de todos os seus familiares.

A equipe de saúde deve ter como finalidade humanizar todo o processo de gestação, parto e pósparto, dando suporte as gestantes para que possam ter a melhor experiência possível. Valorizando a mulher como ser humano que tem suas questões biológicas, psicológicas, sociais e religiosas e não um ser fragmentado em seus sistemas funcionais. Com isso os profissionais poderão assistir a gestante de maneira correta, respeitando suas vontades e seus desejos.

Foi possível perceber como o papel do acompanhante é fundamental no processo de humanização do parto e pós-parto, em virtude deste poder passar calma, apoio, dedicação, incentivo. Contudo percebe-se que apesar de ser reconhecido como lei a presença do acompanhante para junto a gestante, a presença deste ainda é vista com uma questão difícil pelos os profissionais de saúde devido à falta de uma delimitação clara e prática do seu espaço no contexto parto. 
Torna-se de suma importância que durante o pré-natal as informações sejam completas, demonstrado as gestantes os seus direitos. Só que para isso ocorrer é preciso profissionais qualificados e especializados em obstetrícia para que a gestante seja cuidada, respeitada, com ética e que o enfermeiro seja um incentivador mostrando a gestante que é possível ser sim protagonista do seu trabalho de parto. 


\section{RFERÊNCIAS}

ANVISA. Agência Nacional de Saúde Suplementar. O modelo de atenção obstétrica no setor de Saúde Suplementar do Brasil: cenários e perspectivas. Rio de Janeiro: ANS, 2008.158p. Disponível em:

http://bvsms.saude.gov.br/bvs/publicacoes/modelo_atencao_obstetrica.pdf Acesso em: 07 out. 2019.

BALASKAS, Janet. O que é um Parto Ativo? In: . Parto Ativo: guia prático para o parto natural (a história e a fisiologia de uma revolução). 3. ed. rev., atual. e aum. São Paulo: Ground, p. 47-74. 2015. Acesso: 27 de setembro de 2019

Disponível:

https://issuu.com/groundaquarianaeditorial/docs/degustacao_parto_ativo_nova_edicao_

BERMEJO, J. C. Humanizar a saúde: Cuidado, relações e valores. Petrópolis, Rio de Janeiro: Editora Vozes. 2008 Acesso em: 30 de setembro de 2019.

BRASIL. Ministério de saúde. Secretaria de Atenção à Saúde. Departamento de ações Programáticas Estratégicas. Pré natal e Puerpério - Atenção Qualificada e Humanizada. Manual Técnico. Série Direitos Sexuais e Reprodutivos. Brasília - DF. 2006. Disponível em:

https://www.nescon.medicina.ufmg.br/biblioteca/imagem/1926.pdf Acesso em: 27 set. 2019

BRASIL. Ministério da Saúde. Secretaria de Atenção à Saúde. Parto e nascimento domiciliar assistidos por parteiras tradicionais: o Programa Trabalhando com Parteiras Tradicionais e experiências exemplares. Brasília: Ministério da Saúde, 2010. 90p. Disponível em:

http://bvsms.saude.gov.br/bvs/publicacoes/parto_nascimento_domiciliar_parteiras.pdf Acesso em: 30 set. 2019.

BRASIL. Gravidez, parto e nascimento com saúde, qualidade de vida e bem-estar. 1a ed. Brasília: Ministério da Saúde, 2013. Disponível em:

http://bvsms.saude.gov.br/bvs/publicacoes/gravidez_parto_nascimento_saude_qualidade.pdf Acesso em: 30 set. 2019.

BRASIL. Ministério da Saúde. Portaria no. 11, de 07 de janeiro de 2015. Redefine as diretrizes para implantação e habilitação de Centro de Parto Normal (CPN), no âmbito do Sistema Único de Saúde (SUS), para o atendimento à mulher e ao recémnascido no momento do parto e do nascimento, em conformidade com o Componente PARTO E NASCIMENTO da Rede Cegonha, e dispõe sobre os respectivos incentivos financeiros de investimento, custeio e custeio mensal. Brasília: Ministério da Saúde [2015]. Disponível em:

http://bvsms.saude.gov.br/bvs/saudelegis/gm/2015/prt0011_07_01_2015.html Acesso em: 28 set. 2019.

COREN SP. Conselho Regional de Enfermagem de São Paulo. Parto Natural. São Paulo, v.1,2010. Disponível 
em: http://portal.coren-sp.gov.br/sites/default/files/revista_enfermagem_julho_2009_0.pdf Acesso em: 01 out. 2019.

DICIO, DICIONÁRIO ONLINE DE PORTUGUÊS, Definições e significados de mais de 400 mil palavras. (2009- 2019). Disponível em: https://www.dicio.com.br/humanizar/ Acesso em: 03 out. 2019.

DINIZ, C. S. Humanização da assistência ao parto no Brasil: os muitos sentidos de um movimento. Ciências de Saúde Coletiva, v. 10, n. 3, p.627-37. 2005. Acesso em 02 de outubro de 2019.

Disponível: http://revistaseletronicas.pucrs.br/ojs/index.php/civitas/article/view/17899

DIAS, M. A. B.; DOMINGUES, R. M. S. M. Desafios na implantação de uma política de humanização da assistência hospitalar ao parto. Ciências \& Saúde Coletiva, v. 10, n. 3, p. 699-705, 2005. Acesso em 30 de setembro de 2019.

Disponível:http://www.scielo.br/scielo.php?pid=S141381232005000300026\&script=sci_abstract\&tln $\mathrm{g}=\mathrm{pt}$

LEISTER, N; RIESCO, M L G. Assistência ao parto: história oral de mulheres que deram à luz nas décadas de 1940 a 1980. Texto Contexto Enferm, Florianópolis, v. 22, n. 1, p. 166-174, jan-mar. 2013. Acesso em: 03 de outubro de 2019.Disponível: http://www.scielo.br/pdf/tce/v22n1/pt_20.pdf

OLIVEIRA, J. D. G. Atuação do enfermeiro obstetra na assistência à parturiente: percepções do profissional. 2015. Artigo Cientifico (Graduação em Enfermagem) - Faculdade de Ciências da Saúde do Trairi, UFRN, Santa Cruz, 2015. Versões impressa e eletrônica. Disponível em: https://monografias.ufrn.br/jspui/bitstream/123456789/1542/1/Atuação\%20do\%20Enfermeiro\%20 Obstetra\%20na\%20Assistência\%20a\%20Parturientes.pdf Acesso em: 01 set.2019.

PINHEIRO, B C; BITTAR, C M L. Expectativas, percepções e experiências sobre o parto normal: relato de um grupo de mulheres. Fractal, Rev. Psicol., v.25, n.3, 2013. Acesso em 30 de setembro de 2019.

Disponível:http://www.scielo.br/scielo.php?script=sci_arttext\&pid=\$1984-02922013000300011

REIS, A E; ZULEICA, M P Aplicação das ações preconizadas pelo Ministério da Saúde para o parto humanizado em um hospital de santa Catarina. Ciênc. Saúde Coletiva.p30221.2005. Acesso em 1o de outubro de 2019.

Disponível:http://www.scielo.br/scielo.php?script=sci_arttext\&pid=S1413-81232005000500023

ROCHA, F. A. A.; FONTENELE, F. M. C.; CARVALHO, I. R.; RODRIGUES, I. D. C. V; SOUSA, R. A.; FERREIRA JÚNIOR, A. R. Cuidado no parto e nascimento: percepção de puérperas. Rev. Rene, Fortaleza, v.16, n.6, p.782-789. 2015. Acesso Disponível em:

http://repositorio.ufc.br/bitstream/riufc/14743/1/2015_art_faarocha.pdf Acesso em: 01 set.2019.

SENA, Chalana D. de et al. Avanços e retrocessos da enfermagem obstétrica no Brasil. Revista de Enfermagem da UFSM, [S.I.], v. 2, n. 3, p. 523-529, set.-dez. 2012. Acesso: 30 de setembro de 2019

Disponível em: https://periodicos.ufsm.br/reufsm/article/view/3365/pdf 
VARGENS, O. M. da C. et al. Parto e nascimento: saberes e práticas humanizadas. Texto Contexto Enfermagem, Florianópolis, v. 21, n. 2, p. 329-337, abr. - jun. 2012. Acesso em 02 de setembro de 2019.

Disponível em: http://www.scielo.br/pdf/tce/v21n2/a10v21n2 .

VEZO, CORONEL, ROSÁRIO, S. O. do. Assistência Humanizada de Enfermagem no Trabalho de Parto. Escola superior de saúde. Curso de licenciatura em enfermagem. 2013.

Acesso em 25 de setembro de 2019.

Disponível:

http://www.portaldoconhecimento.gov.cv/bitstream/10961/3251/1/Vezo\%2C\%20Coronel\%20e\%20 Ros\%C3\%A1rio\%202013.\%20Assist\%C3\%AAncia\%20humanizada\%20de\%20enfermagem\%20no\%20tr abalho\%20de\%20parto.pdf

WALDOW, Vera R. Enfermagem e o cuidado: uma relação. In: . Cuidar: expressão humanizadora da enfermagem. 3. ed. Petrópolis: Vozes, p. 63-85. 2010. Acesso em: Primeiro de setembro de 2019. 


\section{Capítulo 2}

d.)

\section{ASSISTÊNCIA HUMANIZADA DE ENFERMAGEM DIRECIONADA À GESTANTE E AS VANTAGENS SOBRE A CESARIANA}

Diulle Ellen da Silva Santos

Eliana Amaro de Carvalho Caldeira

Raquel de Oliveira Martins Fernandes

Laércio Deleon de Melo

Leone Mendes Dias

Camila Cristina Gregório de Assis

Juliana de Lima Brandão

Thaís Vidal de Oliveira

Felipe Eduardo Taroco

Josilene Sobreira Rodrigues
Enfermeira Graduada pelo Centro

Universitário Estácio de Juiz de Fora, Brasil.

Enfermeira. Doutoranda em Saúde Coletiva pela Universidade Federal de Juiz de Fora, Brasil

Enfermeira. Mestre em Enfermagem pela Universidade Federal de Juiz de Fora, Brasil.

Enfermeiro. Doutorando em Enfermagem pela Universidade do Estado do Rio de Janeiro, Brasil

Enfermeiro. Mestre em Enfermagem pela Universidade Federal de Juiz de Fora, Brasil.

Enfermeira. Mestranda em Enfermagem pela Universidade Federal de Juiz de Fora, Brasil.

Enfermeira. Doutoranda em Enfermagem pela Universidade do Estado do Rio de Janeiro, Brasil.

Enfermeira. Mestre em Enfermagem pela Universidade Federal de Juiz de Fora, Brasil.

Acadêmico de Fisioterapia pelo Centro Universitário Estácio de Juiz de Fora, Brasil.

Acadêmica de Enfermagem pelo Centro Universitário Estácio de Juiz de Fora, Brasil. 


\section{Resumo:}

Introdução: o parto normal segue no decorrer dos anos cercados de mitos e preconceitos com relação à dor, tempo gestacional, dentre outros, que acabam impactando na escolha da gestante. 0 enfermeiro possui diversas funções durante o processo do parto/nascimento e é o mais qualificado à desmistificar estas histórias que ultrapassam gerações, direcionando a gestante a fazer a melhor escolha para dar à luz. Objetivou-se identificar as funções do enfermeiro em toda a trajetória do parto acentuando a importância de um parto fisiológico, dentro das possibilidades de cada mulher. Foi realizada uma pesquisa de revisão bibliográfica com base nos dados da Scientific Electronic Library Online (SciELO), da Literatura Latino-americana e do Caribe em Ciências da Saúde (LILACS), da Base de Dados de Enfermagem (BDENF) e dos portais do Ministério da Saúde. Desenvolvimento: totalizaramse 15 artigos publicados entre o ano de 2003 e 2018. Embasado nas informações disponíveis nos artigos, foram destacadas importância de uma assistência humanizada e desmedicalizada e também as relevantes contribuições do enfermeiro para auxílio à parturiente na tomada de decisão a respeito da via de parto. Conclusão: o enfermeiro é um dos profissionais mais indicados para a atuação na assistência centrada às necessidades da gestante, devido sua forma de cuidado humanizado e empático, auxiliando assim, na redução do número de partos cirúrgicos sem real indicação.

Palavras chave: Enfermeiro. Parto Normal. Cuidado Pré-Natal. 


\section{INTRODUÇÃO}

Antigamente, quando as formas de cuidados eram predominantemente empíricas, os partos eram feitos no ambiente domiciliar exclusivamente por mulheres que assistiam o parto com a função de auxiliar o processo parturitivo; contudo, esta característica começou a se perder no século XVIII, e então no século XX o modelo hospitalocêntrico e a medicalização do processo tomaram conta deste cenário (MOURA et al., 2007). Junto com estas mudanças vieram as práticas intervencionistas, como a medicalização do corpo e a episiotomia, que a princípio eram métodos para serem utilizados em casos necessários onde a gestante e o bebê pudessem correr riscos de vida (CARNEIRO et al., 2015).No século XX o parto cirúrgico, até então utilizado apenas em casos de risco materno e neonatal, se tornou mais popular e ganhou força, assumindo a via mais utilizada de nascimento, porém seu uso excessivo e indiscriminado começou a mudar a realidade do parto fisiológico gerando alterações significativas no campo obstétrico e consequentemente nos números de morte materna e infantil (KOTTWITZ; GOUVEIA; GONÇALVES, 2018).

A Organização Mundial de Saúde (OMS), em 1985, questionou as práticas intervencionistas e propôs o uso de métodos atualizados e adequados para o parto, que continham alterações nas rotinas hospitalares e principalmente a inclusão de enfermeiras para assistência ao parto. Foi no Rio de Janeiro, nos anos 90, que estas propostas da OMS de empoderamento feminino como motivação para o parto normal, começaram a fazer com que as enfermeiras fossem inseridas no cenário do parto, neste mesmo momento, o Ministério da Saúde (MS) investia na capacitação destas enfermeiras (PRATA; PROGIANTI, 2013).

No ano de 2009, o Brasil apresentou a taxa de 50,10 \% de partos cesarianos, a Região Sudeste um valor de 56,76 \% e mais precisamente, em Minas Gerais, onde a presente revisão foi realizada, a percentagem de $52,06 \%$, números extremamente mais altos que os preconizados pela OMS e pelo MS (BRASIL, 2009).

Em 2016, o total de mortes maternas no estado de Minas Gerais foi de 119 óbitos, e na cidade de Juiz de Fora ocorreu 6,10\% (5 óbitos) deste total (BRASIL, 2016). Os índices de mortalidade materna e perinatal ainda hoje apresentam um desafio para a saúde pública, devido à variabilidade de causas destes óbitos. Porém, é sabido que a prevenção destes índices pode se dar num acompanhamento adequado durante o pré-natal e numa assistência efetiva e individualizada (MOURA et al, 2007). 
A partir destas considerações o presente estudo objetivou-se descrever as vantagens da humanização do parto e a participação do enfermeiro na assistência obstétrica e prevenção de intervenções, como forma de reduzir a taxa de morbimortalidade materna e perinatal. Desta forma, o mesmo se justifica pela necessidade do conhecimento dos benefícios da humanização para a realização de uma assistência efetiva.

A escolha do tema foi originada a partir da percepção da necessidade em se discutir mais sobre o assunto que, apesar de ser bastante abordado, ainda apresenta dificuldades em sua implementação. Todavia, para se programar ações a fim de mudar os problemas apresentados, é necessário um amplo conhecimento sobre a assistência em si, dada enfim a relevância deste estudo.

O presente estudo trata-se de uma revisão bibliográfica realizada nos meses de outubro e novembro de 2018 e que possibilita uma reflexão crítica acerca do assunto. As bases de dados que possibilitaram as pesquisas foram: Literatura Latino-Americana e do Caribe em Ciências da Saúde (LILACS), Scientific Electronic Library Online (SciELO) e Base de dados de Enfermagem (BDENF), além dos portais do Ministério da Saúde. Em todas as bases de dados foram utilizados, para a pesquisa, os Descritores em Ciências de Saúde (DeCS): Enfermeiro e Parto normal, combinados entre si pelo conector booleano "AND".

Os critérios de inclusão para a seleção dos artigos desta pesquisa foram: artigos que discorressem sobre as participações do enfermeiro na assistência humanizada ao parto normal; idioma português; publicados entre os anos de 2006 à 2018 e disponibilizados em sua versão integral, gratuita e online. O recorte temporal para análise de artigos se deu com a intenção de descrever algumas das principais mudanças nos anos seguintes à implementação do PNH até a presente data. Foram excluídos artigos que não se encaixavam nos critérios de inclusão, teses, relatos de caso, dissertações e literatura cinzenta. A figura 1 representa o diagrama contendo o número total de artigos encontrados nas três bases de dados e os artigos selecionados de acordo com os critérios de inclusão e exclusão utilizada no momento da busca. 
Figura 1 - Diagrama de resultado da utilização dos critérios de inclusão e exclusão.

TOTAL DE ARTIGOS
ENCONTRADOS NAS BASES DE
\begin{tabular}{|lr}
\hline \multicolumn{2}{|c}{ DADOS: 517} \\
\hline SCIELO: & 125 \\
BDNEF: & 184 \\
LILACS: & 208 \\
\hline
\end{tabular}

\begin{tabular}{|lr|}
\hline \multicolumn{2}{|c|}{ ESTUDOS EXCLUÍDOS POR NÃO } \\
ATENDEREM AOS CRITÉRIOS DA \\
\multicolumn{2}{|c|}{ QUESTÃO NORTEADORA: } \\
\hline SCIELO: & $\mathbf{1 2 3}$ \\
BDNEF: & 176 \\
LILACS: & 204 \\
\hline
\end{tabular}

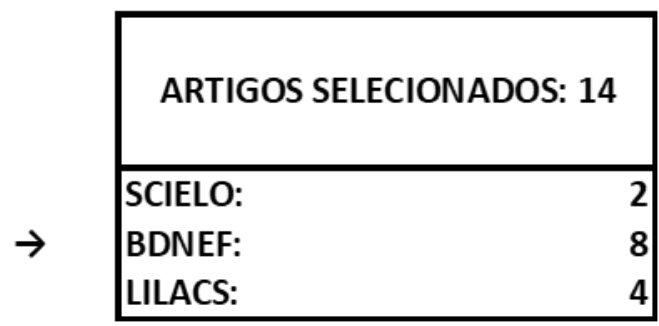

\section{DESENVOLVIMENTO}

De acordo com os critérios de inclusão e exclusão, foram selecionados 14 artigos da literatura científica organizados no quadro 1 de acordo com os autores, títulos e objetivos dos estudos para melhor análise dos artigos.

Quadro 1-Distribuição dos artigos selecionados para a revisão bibliográfica

\begin{tabular}{|c|c|c|}
\hline Autores & Títulos & Objetivos \\
\hline $\begin{array}{l}\text { CARNEIRO et al, } \\
2015\end{array}$ & $\begin{array}{l}\text { Parto normal x parto cirúrgico: } \\
\text { percepções de mulheres que } \\
\text { vivenciaram os dois momentos. }\end{array}$ & $\begin{array}{l}\text { Identificar a percepção de mulheres referente ao } \\
\text { parto natural e parto cirúrgico. }\end{array}$ \\
\hline $\begin{array}{l}\text { CAUS et al., } \\
2012\end{array}$ & $\begin{array}{l}\text { O processo de parir assistido } \\
\text { pela enfermeira obstétrica. }\end{array}$ & $\begin{array}{l}\text { Compreender o significado que a parturiente } \\
\text { atribui ao processo de parir assistido pela } \\
\text { enfermeira e identificar as contribuições deste } \\
\text { processo para promover o cuidado humanístico. }\end{array}$ \\
\hline $\begin{array}{c}\text { COELHO;VERGARA, } \\
2015\end{array}$ & $\begin{array}{l}\text { Teoria de Paterson e Zderad } \\
\text { Aplicabilidade Humanística no } \\
\text { parto normal. }\end{array}$ & $\begin{array}{l}\text { Descrever e incitar a reflexão à respeito da } \\
\text { contribuição à relação teórico-prática } \\
\text { humanizada no parto normal à luz da teoria } \\
\text { humanística. }\end{array}$ \\
\hline $\begin{array}{c}\text { KOTTWITZ; } \\
\text { GOUVEIA; } \\
\text { GONÇALVES, }\end{array}$ & $\begin{array}{c}\text { Via de parto preferida por } \\
\text { puérperas e suas motivações. }\end{array}$ & $\begin{array}{c}\text { Conhecer a via de parto preferida pelas } \\
\text { puérperas e as motivações que a levaram à } \\
\text { escolha. }\end{array}$ \\
\hline
\end{tabular}




\begin{tabular}{|c|c|c|c|}
\hline 2018 & & & \\
\hline $\begin{array}{c}\text { MACHADO; PRAÇA, } \\
2006\end{array}$ & $\begin{array}{l}\text { Centro de parto normal e } \\
\text { assistência obstétrica centrada } \\
\text { às necessidades da paciente. }\end{array}$ & 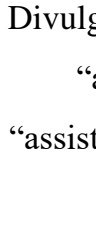 & $\begin{array}{l}\text { proposta de substituição da expressão } \\
\text { tência humanizada ao parto", por } \\
\text { la obstétrica centrada nas necessidades } \\
\text { da parturiente". }\end{array}$ \\
\hline $\begin{array}{l}\text { MOURA et al, } \\
2007\end{array}$ & $\begin{array}{l}\text { A humanização e a assistência } \\
\text { de enfermagem ao parto normal }\end{array}$ & $\begin{array}{l}\text { Ide } \\
\text { huma }\end{array}$ & $\begin{array}{l}\text { car a atuação da enfermagem sobre } \\
\text { ç̧ão e assistência de ao parto normal. }\end{array}$ \\
\hline PIMENTA et al., 2013 & $\begin{array}{l}\text { A cultura interferindo no desejo } \\
\text { sobre o tipo de parto. }\end{array}$ & Ente & $\begin{array}{l}\text { de que forma a cultura influencia no } \\
\text { ocesso parturitivo da gestante. }\end{array}$ \\
\hline $\begin{array}{c}\text { PRATA; } \\
\text { PROGIANTI, } \\
2013\end{array}$ & \multicolumn{2}{|c|}{$\begin{array}{c}\text { A influência da prática das enfermeiras } \\
\text { obstétricas na construção de uma nova } \\
\text { demanda social. }\end{array}$} & $\begin{array}{l}\text { Discutir as percepções e analisar os } \\
\text { efeitos da prática das enfermeiras } \\
\text { obstétrica na vidadas mulheres. }\end{array}$ \\
\hline $\begin{array}{l}\text { ROCHA; FONSECA, } \\
2010\end{array}$ & $\begin{array}{l}\text { Assistência do enfermeiro } \\
\text { obstetra à mulher parturiente: } \\
\text { em busca do respeito à } \\
\text { natureza. }\end{array}$ & $\begin{array}{r}\text { Carac } \\
\text { nú } \\
\text { assis }\end{array}$ & $\begin{array}{l}\text { zar as parturientes, através da idade e } \\
\text { de consultas pré-natal e analisar a } \\
\text { ia realizada pelos enfermeiros á elas. }\end{array}$ \\
\hline $\begin{array}{c}\text { RODRIGUES, SILVA, } \\
2018\end{array}$ & $\begin{array}{l}\text { Parto eutócico versus cesariana } \\
\text { eletiva e o impacto no } \\
\text { desenvolvimento da } \\
\text { competência da criança. }\end{array}$ & $\begin{array}{r}\text { Veri } \\
\text { entre } \mathrm{C} \\
\text { de } \mathrm{C}\end{array}$ & $\begin{array}{l}\text { se existem diferenças significativas } \\
\text { scidos de parto eutócico e os nascidos } \\
\text { iana eletiva no desenvolvimento de } \\
\text { competências aos } 2 \text { anos. }\end{array}$ \\
\hline $\begin{array}{l}\text { SANTOS et al, } \\
2016\end{array}$ & $\begin{array}{c}\text { Preparo e percepções de } \\
\text { gestantes sobre as vias de parto. }\end{array}$ & $\begin{array}{l}\text { Des } \\
\text { gesta }\end{array}$ & $\begin{array}{l}\text { er o preparo e as informações que as } \\
\text { possuem à respeito das vias de parto. }\end{array}$ \\
\hline $\begin{array}{c}\text { SILVA; } \\
\text { NASCIMENTO; } \\
\text { COELHO, } \\
2015\end{array}$ & $\begin{array}{l}\text { Práticas de enfermeiras para } \\
\text { promoção da dignificação, } \\
\text { participação e autonomia de } \\
\text { mulheres no parto normal. }\end{array}$ & partic & $\begin{array}{l}\text { hecer as práticas realizadas pelas } \\
\text { eiras para autonomia, dignificação e } \\
\text { ão da mulher no processo parturitivo. }\end{array}$ \\
\hline $\begin{array}{l}\text { SILVA et al., } \\
2017\end{array}$ & $\begin{array}{l}\text { Preferência pelo tipo de parto, } \\
\text { fatores associados à expectativa } \\
\text { e satisfação com o parto. }\end{array}$ & A & $\begin{array}{l}\text { sar a satisfação e a preferência das } \\
\text { a respeito do tipo de parto realizado. }\end{array}$ \\
\hline $\begin{array}{l}\text { SOARES et al, } \\
2017\end{array}$ & $\begin{array}{l}\text { A informação de mulheres para } \\
\text { a escolha do processo de } \\
\text { nascimento. }\end{array}$ & $\begin{array}{l}\text { Reali } \\
\text { refere }\end{array}$ & $\begin{array}{l}\text { Ima analise reflexiva e uma discussão } \\
\text { ao processo de informação da mulher } \\
\text { bre a escolha do tipo de parto. }\end{array}$ \\
\hline
\end{tabular}




\subsection{HISTÓRIA DO PARTO}

De modo histórico o parto se tratava de um evento de responsabilidades e participações exclusivamente femininas realizado apenas com o conhecimento das doulas, mulheres que acompanham o parto e não possuem um conhecimento científico, porém, no século XX mais precisamente na década de 40 , começou a se intensificar a hospitalização do parto permitindo a medicalização e o controle da gestação (MOURA et al., 2007).

Diante destas mudanças, a mulher passa a perder sua autonomia e é imposta à normas médicohospitalares desconhecidas, o parto então, se torna sinônimo de medo, dor e muitas vezes trauma (MOURA et al., 2007).

A forma mais conhecida de intervenção no parto é a cesariana, uma incisão cirúrgica nas paredes abdominais que viabiliza o acesso ao útero, possibilitando a extração do feto (PIMENTA et al., 2013). A cesariana eletiva é aquela que predetermina o horário e local do nascimento da criança, muitas vezes por interesses financeiros das instituições, conveniência de programação de horários dos médicos e desinformação das gestantes (SOARES et al.,2017).

Em 1993, um encontro de indivíduos envolvidos no movimento de parto e nascimento discutiu o cenário de nascimento no país, resultando na Carta de Campinas. Esta carta denunciava o alto índice de cesarianas no Brasil e a forma de assistência violenta e desumana prestada à gestante e ao bebê. A proposta era descrever os riscos que mãe e filho corriam mediante ás praticas intervencionistas desnecessárias, resgatar o aspecto cultural do nascimento e empoderar as mulheres em sua participação ativa, autonomia e tomada de decisões no que envolvesse seu corpo e seu parto, equiparando assim o conhecimento técnico-científico às praticas humanizadas de assistência (BRASIL, 1993).

Diante deste cenário e destas mudanças na assistência ao parto surgiram algumas alternativas para auxiliar na efetivação deste novo modelo de assistência, como o Programa Nacional de Humanização (PNH) e os Centros de Parto Normal (CPN). O PNH, criado em 2003, citava a efetivação dos princípios do Sistema Único de Saúde (SUS) e uma intercomunicação entre os gestores e usuários que facilitasse a utilização dos serviços (BRASIL, 2013). Já os CPN's, estruturas destinadas ao parto, tiveram como base algumas localizações onde a atuação de enfermeiros no parto normal era mais habitual e onde eles pudessem contribuir de forma mais ativa no empoderamento da mulher no momento do parto e no resgate de sua autonomia (SILVA; NASCIMENTO; COELHO, 2015). 


\subsection{HUMANIZAÇÃO DA ASSISTÊNCIA}

Diante da ênfase que passou a se dar as intervenções no cenário obstétrico, fez-se necessário rever o modelo da assistência e planejar ações que incluíssem a humanização no parto normal (COELHO; VERGARA, 2015). Em 2001 o MS implementou o Programa Nacional de Humanização da Assistência Hospitalar (PNHAH) que propôs ações que humanizassem a assistência pública do país, resultando na melhora da qualidade e eficácia dos serviços prestados. Estas mudanças deveriam alterar as características de atendimento dos hospitais e profissionais de saúde, para que se adequassem a um atendimento humanístico e empático (BRASIL, 2001).

O Ministério da Saúde com o intuito de sanar os problemas na assistência cria uma rede de atenção que busca a maior efetividade do cuidado pré-natal, parto e puerpério facilitando o acesso, melhorando a qualidade e abrangência do serviço, denominada Rede Cegonha. A Rede Cegonha tem como principal intuito a implementação de cuidados que garantam o direito do bebê de nascer e crescer de uma forma saudável e segura, e da gestante em receber atenção humanizada no parto e puerpério, além do direito de seu planejamento reprodutivo (BRASIL, 2011)

Os CPN's são as principais estruturas para a efetivação da humanização da assistência, são locais direcionados ao parto, porém, distantes do ambiente cirúrgico, com características próximas a um ambiente familiar, programado para atender as necessidades da gestante possibilitando sua total participação, autonomia e privacidade. Eles têm como principal objetivo a promoção do empoderamento da mulher na hora do parto sem deixá-la desamparada das tecnologias que garantam segurança nos casos de intercorrências (MACHADO; PRAÇA, 2006).

Segundo Machado e Praça, (2006) a linha entre as nomenclaturas "assistência centrada às necessidades da paciente" e "assistência humanizada" é tênue; tendo a primeira nomenclatura uma corroboração com a idéia do assunto, sendo melhor e mais amplamente capaz de atender aos ideais da assistência em si.

O processo humanização do parto busca desmedicalizar este momento, devolvendo sua característica fisiológica e trazendo à mulher de volta seu protagonismo, autonomia e privacidade; além de evitar intervenções desnecessárias. Este processo pode ser descrito como um conjunto de medidas, práticas e conhecimentos voltados à promoção do ato fisiológico de parir e à diminuição do alto número de intervenções cirúrgicas (ROCHA; FONSECA, 2010). 
A humanização da assistência de enfermagem baseia-se na necessidade de os enfermeiros melhor compreenderem o processo fisiológico do parto promovendo um nascimento sem intervenções desnecessárias levando em conta todo o aspecto cultural e social que envolve a realidade da família, a qual ele deve apoiar e garantir seus direitos (MOURA et al., 2007).

Em corroboração, a Teoria de Enfermagem Humanística desenvolvida por Josephine Paterson e Loreta Zderad propõe um mecanismo de aproximação à mulher, que busca entender suas reais necessidades por meio do diálogo e aproximação entre os profissionais de saúde e os clientes. Estas e outras propostas de humanização visam a proteção da saúde física e emocional da gestante que tem como consequência a diminuição das possíveis complicações no desfecho do parto (COELHO; VERGARA, 2015).

O estreitamento da relação entre o profissional de saúde e a gestante nesta forma de assistência, vai além de uma aproximação no momento do parto, requer a antevisão dos possíveis impasses presentes em cada situação de cada pessoa. O Enfermeiro, ao prestar os cuidados deve ampliar seus horizontes além de uma avaliação física e emocional, seu atendimento deve analisar o indivíduo como um todo, levando em consideração principalmente aquilo que o cliente não diz, sabendo interpretar seus sinais e gestos a fim de conhecer a história dele por completo. Sendo o tipo de assistência, voltadas às demandas e individualidades de cada um, o profissional deve analisar o contexto do cliente para prestar a melhor e mais adequada forma de cuidado, levando em consideração questões culturais, sociais, financeiras e religiosas que podem apresentar grande importância para a relação interpessoal e para um cuidado totalitário (MACHADO; PRAÇA, 2006).

\subsection{O CONHECIMENTO DA GESTANTE SOBRE AS VIAS DE PARTO}

O parto é um momento delicado que deixa a mulher sensível e vulnerável devido ás alterações sociais, físicas e emocionais que ocorrem, além de dores e desconforto, ansiedade, dúvidas e medos que, se não acompanhados de perto por um profissional empático e capacitado, podem acarretar prejuízos em seu desfecho (SILVA; NASCIMENTO; COELHO, 2015).

Sabe-se que é no pré-natal que se pode adotar medidas de educação em saúde para preparar e instruir a mulher e sanar suas dúvidas com relação á escolha da via de parto (KOTTWITZ; GOUVEIA; GONÇALVES, 2018). Porém, as primeiras informações que parturientes recebem sobre a gestação, geralmente vem de familiares e pessoas próximas que contam com um conhecimento advindo de suas próprias experiências, o que pode influenciar diretamente na escolha da gestante, uma vez que as 
experiências vivenciadas tendem a ser diferentes devido ao contexto e individualidade de cada gestante (SOARES et al.,2017). Além das informações adquiridas no cenário de pré-natal e de familiares, o conhecimento da gestante pode estar relacionado ás suas próprias percepções, formadas a partir de experiências anteriores, expectativas ou visão de mundo (SANTOS et al., 2016).

No estudo realizado por SILVA et al., 2017 os autores observaram que mulheres que receberam as informações e suporte necessários apresentaram maior facilidade em fazer seu próprio planejamento de parto, presumindo-se que o acompanhamento profissional à esta gestante tenha sido efetivo e estes resultados alcançados na forma de educação em saúde estejam ligados à redução do número de cesarianas eletivas e morte materna e infantil.

É de suma importância que o profissional de enfermagem, preparado com os devidos conhecimentos específicos, esteja pronto a esclarecer as dúvidas da gestante em relação ao parto a fim de norteá-la a uma escolha correta, para que com todas as informações necessárias, ela se torne apta a exercer sua autonomia e não se deixe influenciar caso a cesariana the seja imposta (SOARES et al., 2007).

A instrução da mulher no âmbito da escolha de sua via de parto é a peça chave para o empoderamento feminino quanto a seus direitos, sua autonomia e uma assistência adequada e singular. É a partir da boa instrução de um profissional capacitado que a mulher pode reivindicar o direito de protagonizar seu parto e não se tornar parte da sua história, mas ter o direito de conduzi-la (SOARES et al., 2017). A mulher pouco instruída e com conhecimento limitado de seu corpo, tende a perder sua capacidade de autonomia e se deixar influenciar pelas escolhas da equipe de saúde (KOTTWITZ; GOUVEIA; GONÇALVES, 2018).

\subsection{ATUAÇÃO DA ENFERMEIRA OBSTÉTRICA NA ASSISTENCIA HUMANIZADA}

Em 1832 os "Cursos de Parto" deram início à obstetrícia no Brasil e eram realizados nos cursos de farmácia e medicina para só então, em 1922 serem incluso no âmbito da enfermagem. A partir de 1998, o Ministério da Saúde disponibiliza meios de qualificação para que as Enfermeiras Obstétricas sejam inseridas nos campos de parto (MOURA et al., 2007).

A partir da sugestão dos movimentos de mudança da assistência para a adoção de uma assistência com caráter humanístico, empático e baseado em evidências, as enfermeiras começaram a se especializar e buscar conhecimentos para modificar a prática obstétrica tentando manter o menor número de intervenções possível (PRATA; PROGIANTI, 2013). 
O Ministério da Saúde programou portarias que normatizavam ações para melhorar a assistência prestada e regulamentavam a ação do enfermeiro obstetra, no parto normal de risco habitual, embasados em evidências (MACHADO; PRAÇA, 2006). A resolução do COFEN no 516/2016 alterada pela Resolução COFEN $n^{\circ}$ 524/2016 normatiza as ações do enfermeiro em atendimento à gestante e especifica as atribuições delegadas a eles no cenário da obstetrícia (BRASIL, 2015).

De acordo com Machado e Praça (2006), são ações preconizadas com o intuito da implementação da assistência obstétrica centrada nas necessidades da parturiente: estimulação de métodos não medicamentosos para alivio da dor, massagem, deambulação, exercícios respiratórios, dentre outros. É importante que o profissional respeite a vontade da gestante quanto à escolha da via de parto, e garanta que ela seja respeitada. Ele deve estimular a ingestão de líquidos, promover a interação entre a mãe e a criança estimulando o contato físico a fim de fortalecer o vínculo afetivo entre ambos, bem como a estimulação do aleitamento precoce.

É função do enfermeiro o acompanhamento no parto e pós-parto imediato até o retorno para seu lar, e após, orientar quanto à importância da continuidade da assistência pela rede do Programa Saúde da Família. No caso de o parto apresentar alguma intercorrência e a parturiente se tornar paciente de alto risco, o enfermeiro deve tomar as providencias necessárias, conforme sua capacitação técnicocientifica a fim de garantir segurança a mãe e filho (BRASIL, 2015).

\subsection{A AUTONOMIA E PROTAGONISMO DA MULHER}

Promover o autoconhecimento da mulher a ajuda a ser capaz de reivindicar seus direitos e se impor enquanto ser humano, como mulher e como gestante. Fazer com que a gestante adquira confiança em si própria, em seu corpo e conheça sua fisiologia, aumenta a possibilidade de que ela esteja mais segura ao optar pelo parto normal (KOTTWITZ; GOUVEIA; GONÇALVES, 2018).

O conhecimento que a mulher tem sobre o tipo de parto possibilita a demanda de uma assistência especificas às suas necessidades. Quando a mulher toma posse de sua autonomia e passa a comandar o processo de parto, ela garante seus direitos enquanto mulher, gestante e ser humano (SOARES et al., 2017).

A necessidade da inclusão da mulher de uma forma ativa na tomada de decisões ao longo de sua gestação precisa ser incentivada, uma ferramenta facilitadora desta ideia é o plano de parto. O Plano de parto é uma ferramenta que viabiliza o contato entre a gestante e a equipe de saúde onde a mulher ou o casal podem expressar suas expectativas a respeito do que desejam que aconteça e do que 
querem evitar no momento do parto, levando em consideração que este é um evento dinâmico onde pode haver intercorrências (KOTTWITZ; GOUVEIA; GONÇALVES, 2018).

A presença de uma enfermeira obstétrica traz consigo uma assistência centrada na valorização da mulher, impulsionando ela a dar o seu melhor, promovendo os acontecimentos no tempo dela e fazendo com que ela se torne o papel principal daquele momento (CAUS et al., 2012). Para se alcançar de fato, o real empoderamento feminino é necessário que a mulher seja atendida da forma menos autoritária possível, sem julgamento preconceitos ou rótulos por parte da equipe para que ela possa se sentir à vontade para participar da escolha da melhor forma de cuidado para si (SILVA; NASCIMENTO; COELHO, 2015).

\subsection{MÉTODOS NÃO FARMACOLÓGICOS PARA ALIVIO DA DOR}

De acordo com Rocha e Fonseca (2010), a atenção à gestante deve ser individualizada e atender às necessidades de cada uma em sua particularidade, desta forma cada gestante e cada parto terá uma série de cuidados que serão realizados, porém, existem alguns cuidados que são mais comuns e quase sempre utilizados para alivio da dor de uma forma não medicamentosa. São eles:

- Exercícios respiratórios: Método que ajuda a mulher manter o controle sobre as contrações. Estes exercícios ajudam, no primeiro estágio, no relaxamento dos músculos do abdome diminuindo o atrito entre e o útero e as paredes abdominais durante as contrações. Num segundo momento chamado de segundo estágio a respiração é utilizada para pressionar a parede do abdome e auxiliar na expulsão do feto. Estas variações respiratórias podem variar uma vez que cada gestante tende a descobrir um ritmo particular que Ihe traga alívio.

- Movimentos pélvicos: Movimentos que auxiliam na dilatação da cérvice e facilitam a saída do feto.

- Deambulação: A posição vertical atua no modo de aliviar a dor e auxiliar as contrações uterinas além de garantir o domínio do trabalho de parto.

- Massagem: este método ajuda no relaxamento e alivio da dor. As massagens alternadas e diversificadas atingem pontos sensoriais diferentes gerando uma maior amplitude do relaxamento. 
- Musicoterapia: Este método alcança melhor seu objetivo com o uso de fones de ouvido, que não deixa dispersar o som. A distração com uma audioterapia de gosto da gestante auxilia na redução no uso de analgésicos.

- Bola: Auxilia na dilatação da cérvice uterina devido aos movimentos circulares que a mulher faz sobre a bola. Essa estimulação também auxilia na expulsão do feto e na prevenção de traumas de vagina e períneo.

- Banho: Proporciona alivio da dor, relaxamento e auxilia na diminuição da produção de adrenalina e aumento de ocitocina e endorfina, que estimula o parto e diminui a dor respectivamente. Afundar em uma banheira, por exemplo, pode encurtar o tempo de trabalho de parto facilitando a expulsão do feto e diminuindo a pressão arterial.

- Banco: Banco semicircular que deixa livre vulva e cóccix auxiliando na dilatação da cérvice

- Aromaterapia: Baseia-se na utilização de aromas de flores e/ou plantas que sejam de gosto da gestante e que tragam relaxamento e sensação de bem-estar. Pode ser realizada na forma de compressas, diluição em água, massagens ou aromatização de ambientes.

\subsection{PRESENÇA DO ACOMPANHANTE NO PARTO}

A lei $n^{\circ} 11.108$ de 7 de Abril de 2005 altera a lei 8.080 de 19 de setembro de 1990 e dispõe sobre o direito da parturiente à presença de um acompanhante no atendimento da rede do Sistema único de Saúde (SUS), porém, mesmo com esta lei não se pode garantir a permissão seja aplicada a todos os centros de parto e nascimento (BRASIL, 2005).

A presença de um acompanhante na sala de parto faz parte do processo de humanização da assistência ao parto. Acredita-se que a mulher que não tem um acompanhante se sinta mais sozinha com medo e sensação de abandono e que estas sensações possam acarretar em alterações psicológicas e afetivas em sua vida, desde traumas até uma dificuldade no relacionamento entre mãe e filho (ROCHA; FONSECA, 2010).

O acompanhante deve ser escolhido pela mulher, e tem a função de apoiar emocional e fisicamente à gestante, a fim de lhe trazer segurança e apoio. É importante que o acompanhante seja instruído pela equipe de saúde ao que deve ser feito, para saber como direcionar sua atenção de forma a ajudar a gestante diminuindo suas dores e medos (MOURA et al., 2007). 
A presença do acompanhante contribui também para a desconstrução da ideia de que somente a mulher é responsável por toda a maternidade (SILVA; NASCIMENTO; COELHO, 2015).

\subsection{O PARTO NORMAL E A CESARIANA}

De acordo com o estudo realizado por Silva et al., (2017), a maior parte das gestantes optam pelo parto normal devido a facilidade e rapidez do procedimento em si e da recuperação.

Outro estudo realizado com uma amostra de 361 puérperas aponta que 77,6\% delas desejam o parto por via vaginal, destas $81,8 \%$ justificaram sua escolha com a rapidez da recuperação que ele oferece (KOTTWITZ; GOUVEIA; GONÇALVES, 2018).

O aspecto mais significante do parto normal apresentado pelas parturientes entrevistadas foi a dor, porém, a maioria alegou ser uma dor que desaparece imediatamente após o nascimento do bebê e possibilita o retorno breve ás atividades normais, contrariamente à cesariana, que no momento cirúrgico não apresenta dor, mas que o pós-operatório se torna longo e doloroso. Neste mesmo estudo os pontos fortes da escolha pelo parto normal, além da recuperação rápida foram: menor incidência de infecções por internação, menor demanda de cuidados pós-procedimentos, além da promoção de um vínculo mais afetuoso entre o binômio mãe e filho, que afinal, foi nascido da mãe num ritual fisiológico e não extraído da mesma num procedimento cirúrgico (CARNEIRO et al., 2015).

Além de seus inúmeros benefícios de caráter naturalista, o parto normal conta com os benefícios emocionais, pela agilidade do processo, ele possibilita um contato mais rápido entre mãe e filho e a rapidez do aleitamento materno, isso ajuda no fortalecimento dos laços entre eles e também na prevenção de diversos danos à saúde do recém-nato (SOARES et al., 2017). O encontro no pós-parto imediato de mãe e filho proporciona o contato entre a pele dos dois, que tem relação direta com a estabilidade de batimentos cardíacos, níveis sanguíneos e frequência respiratória do bebê; além de proporcionar o relaxamento da mãe com diminuição de sua ansiedade e promover o acalento do recém-nato (CARNEIRO et al., 2015).

O parto cesariano, hoje é o mais realizado, cenário alarmante, que contribuiu com a criação de diretrizes focadas na reversão deste quadro, de modo com que se diminua a mortalidade materna e perinatal causada por estas intervenções. O medo por parte das gestantes é um dos possíveis motivos do aumento do número de cesarianas, medo da dor uma vez que o parto normal foi estigmatizado como parto doloroso, medo de alguma intercorrência colocar em risco a vida de seu bebê e até mesmo medo de violência obstétrica (SILVA et al., 2017). Atualmente, o Brasil apresenta um cenário de 
realização de cesarianas epidêmico, contando com um número de 55\% dos partos realizados, o serviço privado é o que mais onera este índice, apresentando uma taxa de $84,6 \%$, ganhando do cenário público que tem $40 \%$ de seus partos cesarianos. A OMS recomenda que as taxas de cesarianas sejam de 10 a 15 por cento, mas, na atualidade os índices apresentados ultrapassam essa preconização tanto em países desenvolvidos como em países em desenvolvimento. A cesárea deve ser tomada como uma medida cirúrgica para reduzir a morbimortalidade materna e perinatal, e adotada somente em casos específicos (BRASIL, 2016).

Considera-se como justificável indicação de cesariana o parto que apresente sofrimento fetal, problemas com a gestante ou com o feto que impossibilitem e/ou dificultem o parto normal, problemas com o tamanho da cabeça do bebê que dificulta a passagem pela pelve materna, alterações cardíacas do feto, dentre outros (SILVA et al, 2017). Em contrapartida, sua realização indiscriminada pode estar diretamente ligada a estes mesmos riscos de morte materna e ou fetal e também à prematuridade (KOTTWITZ; GOUVEIA; GONÇALVES, 2018).

O procedimento da cesariana quando feito sem real necessidade pode acarretar riscos de morte materna e infantil, e aumento das chances de problemas respiratórios na criança, à cerca disto, o Ministério da Saúde (MS) publicou através do Diário Oficial da União o Protocolo Clínico de Diretrizes Terapêuticas (PCDT) da cesariana, que visa a redução no número de cesarianas desnecessárias devido aos possíveis riscos e orientar uma análise criteriosa para a indicação da cesariana baseada em evidências (BRASIL, 2016).

De acordo com Rodrigues e Silva (2018), no estudo que verifica as diferenças cognitivas entre os nascidos de parto cesariano e normal, concluiu-se que a cesariana apresente um déficit das capacidades cognitivas, motoras, visuais e de fala em relação ao parto natural (RODRIGUES; SILVA, 2018).

Acredita-se que na maioria das vezes as indicações de cirurgias são feitas equivocadamente com o intuito de reduzir e otimizar o tempo do nascimento, podendo, os profissionais de saúde se organizarem para realizar mais partos mecanizados sem ter que ficar por horas auxiliando a gestante em trabalho de parto, aumentando assim, seus lucros (SANTOS et al., 2016).

O critério para escolha da via de nascimento ser a via abdominal deve ir muito além de uma análise de tempo gestacional, uma cesariana eletiva e sem real indicação pode acarretar riscos para mãe e filho, a melhor maneira de se evitar, isto é, sem dúvidas, esperar que o bebê decida o momento de nascer (CARNEIRO et al., 2015). 
Entre tantos outros possíveis prejuízos da cesariana, temos a possibilidade de má formação do aparato respiratório do bebê, caso haja algum problema no cálculo da idade gestacional. Este erro pode incidir em síndromes respiratórias, internamento do bebê um uma Unidade de Terapia Intensiva Neonatal e até morte por prematuridade. Qualquer que seja a consequência desta prematuridade, gera um desconforto em toda a família, que aguarda o bebê e principalmente na mãe, que se sente amedrontada e insegura (CARNEIRO et al., 2015).

Todos estes transtornos podem ser evitados com o nascimento natural e no tempo do bebê, até mesmo a probabilidade de problemas respiratórios, porque no momento do trabalho de parto ocorre a preparação do organismo da criança para se adaptar à vida extrauterina (CARNEIRO et al., 2015).

\section{CONSIDERAÇÕES FINAIS}

Diante do presente estudo foi possível concluir que as mudanças que ocorreram com o campo obstétrico ao longo dos anos, resultaram numa assistência fragmentada e biomédica que desvalorizou a capacidade da mulher de dirigir o parto e banalizou o ato de nascer, interferindo diretamente nos altos índices de intervenções cirúrgicas e mortalidade materna e perinatal. A partir deste quadro, surgiu a necessidade de incluir a presença do enfermeiro no campo obstétrico, propondo mudanças que atuassem diretamente no sentido de humanizar o atendimento de uma forma a promover a identidade da mulher como gestante e como ser humano, embasado em conhecimentos e evidências.

Dentre todas as atribuições do enfermeiro podemos perceber que a promoção da autonomia da mulher é uma das mais importantes, ele deve garantir que baseada em informações claras, a gestante se torne apta a participar ativamente de seu processo parturitivo. O enfermeiro deve amparar emocionalmente a mulher, oferecer suporte motivador e salientar a importância de sua participação ativa, além de disponibilizar informações necessárias sobre todos os aspectos relacionados ao parto; sua presença no momento do parto natural fortalece a segurança da mulher quanto à presença de alguém capacitado sem agredir sua privacidade.

Foi possível evidenciar que o enfermeiro deve, mediante suas possibilidades, promover a presença de um acompanhante para fortalecimento das premissas da humanização da assistência, porém, de acordo com os dados levantados neste estudo, conclui-se que muitas das vezes, esta preconização não é cumprida desrespeito 0 direito da mulher.

Quanto ás responsabilidades do enfermeiro, conclui-se que o mesmo deve acompanhar a gestante não só na sala de parto, mas no atendimento pré-natal, com atividades educativas para que ela encare 
o parto vaginal como uma boa experiência, e no puerpério, fornecendo orientações quanto a utilização do programa Saúde da Família.

O presente estudo possibilitou a evidenciação da necessidade dos centros de parto normal e seus benefícios na assistência, uma vez que é considerado o ambiente mais adequado para a promoção da autonomia da mulher, pelas suas características físicas e abstratas. É no centro de parto normal que a mulher se distancia do ambiente hospitalar.

Os levantamentos deste estudo mostraram que o parto vaginal é mais vantajoso do que a cesariana por apresentar uma melhor recuperação, menor risco de infecção hospitalar, fortalecimento dos laços afetivos entre mãe e filho e melhor desenvolvimento cognitivo do bebê, e que a maioria das realizações da cesariana se dão por interesses dos serviços de saúde, falta de informação da gestante acerca das vias de nascimento, influência de pessoas próximas e da mídia e principalmente por medo da dor. O estudo evidenciou ainda que o enfermeiro é o principal objeto de mudança da assistência e efetivação das premissas de humanização.

Destacou-se que o enfermeiro, ao prestar assistência humanizada, atua na redução do número de cesarianas que resulta em morte de mãe e filho e vai além de uma melhor forma de tratar a gestante. Este cuidado reduz os números de morte obstétrica e perinatal e tem uma consequência indireta nos custos da instituição, gerando menor custos com internação, gastos com medicamentos e mobilização de pessoal para atender um determinado parto.

Em suma, concluiu-se que o enfermeiro é o principal facilitador da forma de assistência humanizada, ele, ao prestar este tipo de assistência, não está beneficiando apenas a gestante, está beneficiando a si próprio, numa forma de crescimento pessoal e agregação de valores, dando a outra pessoa, o que ele tem ciência que é a melhor forma de cuidado. Ele deve buscar sempre o aprimoramento de seus conhecimentos e métodos para além de uma assistência humanizada, oferecer um atendimento seguro e de qualidade. 


\section{REFERÊNCIAS}

BRASIL, 1993. Rede pela Humanização do Parto e do Nascimento (REHUNA). Carta de Campinas. Disponível em: < http://www.rehuna.org.br/index.php/14-quem-somos/63-historia>. Acesso em: $07 / 11 / 2018$

Ministério da Saúde, 2001. Secretaria de Assistência à Saúde. Programa Nacional de Humanização da Assistência Hospitalar. Disponível em:

< http://bvsms.saude.gov.br/bvs/publicacoes/pnhah01.pdf>. Acessado em: 11/11/2018.

. Ministério da Saúde, 2005. Lei № 11.108 - De 7 De Abril de 2005. Altera a Lei 8.080, de 19 de Setembro de 1990, para garantir às parturientes o direito à presença de acompanhante durante o trabalho de parto, parto e pós-parto imediato, no âmbito do Sistema Único de Saúde - SUS.Brasília: Diário Oficial da união. Disponível em:

< http://sislex.previdencia.gov.br/paginas/42/2005/11108.htm>. Acesso em: 12/11/2018.

. Ministério da Saúde, 2009. Rede Interagencial de Informação para a Saúde. Proporção de partos cesáreos.. Disponível em: <http://tabnet.datasus.gov.br/cgi/tabcgi.exe?idb2010/f08.def>. Acesso em: 10/11/2018.

. Ministério da Saúde, 2011. Portaria № 1.459, De 24 de Junho de 2011. Institui, no âmbito do Sistema Único de Saúde - SUS - a Rede Cegonha. Disponível em: < http://bvsms.saude.gov.br/bvs/saudelegis/gm/2011/prt1459_24_06_2011.html>. Acessado em: $11 / 11 / 2018$.

. Ministério da saúde, 2013 Folheto Política Nacional de Humanização.. Disponível em: <http://bvsms.saude.gov.br/bvs/publicacoes/politica_nacional_humanizacao_pnh_folheto.pdf $>$. Acesso em: 23/10/2018.

. Conselho Federal de Enfermagem, 2015.Resolução COFEN № 516/2016 - Alterada pela resolução COFEN № 524/2016. Normatiza a atuação e a responsabilidade do Enfermeiro, Enfermeiro Obstetra e Obstetriz na assistência às gestantes, parturientes, puérperas e recém-nascidos nos Serviços de Obstetrícia, Centros de Parto Normal e/ou Casas de Parto e outros locais onde ocorra essa assistência; estabelece critérios para registro de títulos de Enfermeiro Obstetra e Obstetriz no âmbito do Sistema Cofen/Conselhos Regionais de Enfermagem, e dá outras providências. Disponível em: < http://www.cofen.gov.br/resolucao-cofen-no-05162016_41989.html>. Acesso em: 12/11/2018.

Ministério da saúde, 2016. Ministério lança protocolo com diretrizes para parto cesariana. Disponível em: <http://portalms.saude.gov.br/noticias/agencia-saude/22946-ministeriolanca-protocolo-com-diretrizes-para-parto-cesariana> Acesso em: 24/10/2018.

. Ministério da saúde, 2016. Óbitos maternos segundo Município. Disponível em: < http://tabnet.datasus.gov.br/cgi/tabcgi.exe?sim/cnv/mat10MG.def>. Acesso em: 10/11/2018.

CARNEIRO, L.M.A.; PAIXÃO, G.P.N.; SENA, C.D.; SOUZA, A.R.; SILVA, R.S.; PEREIRA, A. Parto natural $x$ parto cirúrgico: percepções de mulheres que vivenciaram os dois momentos. Revista de Enfermagem do Centro Oeste Mineiro, v.5, n.2, p. 1574-1585, mai./ago. 2015. Disponível em: <http://www.seer.ufsj.edu.br/index.php/recom/article/view/744/859>. Acesso em: 01/10/2018 
CAUS, E.C.M.; SANTOS E.K.A.; NASSIF, A.A.; MONTICELLI M. O processo de parir assistido pela enfermeira obstétrica. Revista Escola Anna Nery, v. 16 n. 1 p. 34-40, jan./mar. 2012. Disponível em:<http://www.scielo.br/pdf/ean/v16n1/v16n1a05.pdf>. Acesso em: 05/10/2018.

COELHO, N. R.;VERGARA, L. M. Teoria de paterson e zderad: aplicabilidade humanística no parto normal. Cogitare Enfermagem, v. 20, n. 4, p.829-836, Out./Dez. 2015. Disponível em: <http://www.redalyc.org/pdf/4836/483647681026.pdf>. Acesso em: 01/10/2018.

KOTTWITZ, F.; GOUVEIA, H.G.; GONÇALVEZ, A.C. Via de parto preferida por puérperas e suas motivações. Escola Anna Nery, v. 22, n. 1, p. 1-8. 2018. Disponível em: <http://www.scielo.br/pdf/ean/v22n1/pt_1414-8145-ean-2177-9465-EAN-2017-0013.pdf>. Acesso em: 02/10/2018.

MACHADO, N.X.S.; PRAÇA N.S. Centro de parto normal e assistência obstétrica centrada às necessidades da paciente. Revista Escola de Enfermagem USP v. 40, n. 2, p. 274-279. Disponível em: <http://www.scielo.br/pdf/reeusp/v40n2/16.pdf>. Acesso em: 05/10/2018.

MOURA, F.M.J.S.P.; CRIZOSTOMO, C. D.; NERY, I. S.; ARAÚJO, O. D.; ROCHA, S. S. A humanização e a assistência de enfermagem ao parto normal. Revista Brasileira de Enfermagem, v. 60, n. 4, p. 452-455, ago.2007. Disponível em: <http://dx.doi.org/10.1590/S0034-71672007000400018>. Acesso em: $18 / 10 / 2018$.

Organização Mundial de Saúde. Declaração da OMS sobre Taxas de Cesáreas [Internet]2015. Disponível

em:<http://apps.who.int/iris/bitstream/10665/161442/3/WHO_RHR_15.02_por.pdf?ua=1\&ua=1>. Acesso em: 22 /10/2018.

PIMENTA, L. F; SILVA, S. C, BARRETO, C. N; RESSEL, L. B. A cultura interferindo no desejo sobre o tipo de parto. Revista de Pesquisa Cuidado é fundamental Online, v.6, n.3, p. 987-997,jul./set. 2013. Disponível em: http://www.seer.unirio.br/index.php/cuidadofundamental/article/view/3165/pdf_13 >. Acesso em: 03/10/2018.

PRATA, J. A; PROGIANTI, J. M. A influência da prática das enfermeiras obstétricas na construção de uma nova demanda social. Revista de enfermagem da UERJ, Rio de Janeiro v.21, n.1, p. 23-28, jan/mar, 2013. Disponível em: <www.e-publicacoes.uerj.br/index.php/enfermagemuerj/article/view/6341>. Acesso em: 05/10/2018.

ROCHA, C.R.; FONSECA, L.C. Assistência do enfermeiro obstetra à mulher parturiente: em busca do respeito à natureza. Revista de Pesquisa Cuidado é Fundamental Online, v.2, n. 2, p. 807-816,abr./jun. 2010.. Disponível em:

<http://www.seer.unirio.br/index.php/cuidadofundamental/article/view/339/pdf_19>. Acesso em: 05/10/2018.

RODRIGUES, S.L.M.; SILVA, P.M.M. Parto eutócico versus cesariana eletiva e o impacto no desenvolvimento de competências da criança. Revista de Enfermagem Referência, Coimbra, v. ser IV, n. 16, p. 107-116, mar. 2018. Disponível em: <http://dx.doi.org/10.12707/RIV17056>. Acesso em: 03/10/2018. 
SANTOS, C. L.; BORTOLI, C. F. C.; PRATES, L. A.; GUIMARÃES, K. B.; MASSAFEREA, G. L.; BSOGNIN, P. Preparo e percepções de gestantes sobre as vias de parto. Revista de Enfermagem da UFSM, v. 6, n. 2, p. 186-190, abr./jun. 2016. Disponível em:

<https://periodicos.ufsm.br/reufsm/article/view/19283/pdf>. Acesso em: 05/10/2018.

SILVA, A. L. S.; NASCIMENTO, E. R.; COELHO, E. A. C. Práticas de enfermeiraspara promoção da dignificação, participação e autonomia de mulheres no parto normal. Escola Anna Nery Revista de Enfermagem v. 19, n.3,jul./set. 2015. Disponível em: <http://www.scielo.br/pdf/ean/v19n3/14148145-ean-19-03-0424.pdf>. Acessado em: 01/10/2018.

SILVA, A.C.L.; FÉLIX, H.C.R.; FERREIRA, M.B.G.; WYSOCKI A.D.; CONTIM, D.; RUIZ, M.T. Preferênciapelo tipo de parto fatores associados à expectativa e satisfação com o parto. Revista Eletrônica de Enfermagem [Internet]. 2017. Disponível em: <http://dx.doi.org/10.5216/ree.v19.44139>. Acesso em: 01/10/2018.

SOARES, E. S.; MOREIRA, P.G.S.; RODRIGUES, D. P.; CASTRO, T. M; BARROS, T. C. X; VIANA, A. P. S. A informação de mulheres para a escolha do processo de nascimento. Revista de Enfermagem da UFPE online. Recife, v. 11(Supl. 12), 5427-31, dez. 2017. Disponível em: <https://periodicos.ufpe.br/revistas/revistaenfermagem/article/viewFile/109938/2551>. Acesso em: 05/10/2018. 


\section{Capítulo 3}

\section{CONTRIBUIÇÕES DA ENFERMAGEM NA AMAMENTAÇÃO NA PRIMEIRA HORA DE VIDA DO RECÉM-NASCIDO}

Camila do Carmo Vale

Isabel de Fátima Cruz Silva

Renata Rabelo Rodrigues

Thais Sales de Paula

Raquel de Oliveira Martins Fernandes

Laércio Deleon de Melo

Eliana Amaro de Carvalho Caldeira

Maiara Luci Silva Costa

Lara de Oliveira Loures

Camila Cristina Gregório de Assis
Enfermeira Graduada pelo Centro

Universitário Estácio de Juiz de Fora, Brasil.

Enfermeira Graduada pelo Centro

Universitário Estácio de Juiz de Fora, Brasil.

Enfermeira Graduada pelo Centro

Universitário Estácio de Juiz de Fora, Brasil.

Enfermeira Graduada pelo Centro

Universitário Estácio de Juiz de Fora, Brasil.

Enfermeira. Mestre em Enfermagem pela Universidade Federal de Juiz de Fora, Brasil.

Enfermeiro. Doutorando em Enfermagem pela Universidade do Estado do Rio de Janeiro, Brasil.

Enfermeira. Doutoranda em Saúde Coletiva pela Universidade Federal de Juiz de Fora, Brasil.

Enfermeira Graduada pelo Centro

Universitário Estácio de Juiz de Fora, Brasil.

Enfermeira Pós Graduada em Urgência e Emergência pelo Centro Universitário União das Américas

Enfermeira. Mestranda em Enfermagem pela Universidade Federal de Juiz de Fora, Brasil. 


\section{Resumo:}

Introdução: O presente estudo apresenta as contribuições do enfermeiro na efetivação da amamentação na primeira hora de vida do recém-nascido, sabendo-se que mãe e bebê podem obter benefícios através desta prática, que é recomendada também pela OMS e Ministério da Saúde. Objetivo: Evidenciar as contribuições do enfermeiro na amamentação na primeira hora de vida do recém-nascido. Metodologia: Trata-se de uma revisão bibliográfica da literatura do tipo integrativa; foram utilizados 30 artigos científicos, publicados entre 2015 e 2020, encontrados no acesso eletrônico das bases de dados: Sistema Latino Americano e do Caribe de Informação em Ciências da Saúde (LILACS), Banco de Dados em Enfermagem (BDenf) e na biblioteca eletrônica Scientific Electronic Library Online (SciELO). Revisão: A partir da análise dos artigos foram destacadas as contribuições do enfermeiro desde as orientações no pré-natal, acompanhamento das gestantes, trabalho de parto e parto; objetivando a concretização da mamada precoce. Amamentar não é um ato instintivo do ser humano, é um processo que deve ser aprendido para alcançar êxito, levando em consideração que as mães necessitam de esforço e apoio constantes para que não ocorra o desmame precoce. Considerações Finais: O enfermeiro é um facilitador da mamada precoce. Sua atuação ética e comprometida com o bem estar da puérpera e do seu filho, na sala de parto, no atendimento pósparto imediato, contribui para a efetivação da amamentação ao seio materno na primeira hora de vida do recém-nascido. $O$ enfermeiro concretiza a ação e também sensibiliza toda a equipe envolvida no parto sobre a importância desta prática.

Descritores: Aleitamento Materno; Assistência de enfermagem; Parto Humanizado; Saúde Maternoinfantil; Alojamento Conjunto; Desmame Precoce. 


\section{INTRODUÇÃO}

Amamentar é mais do que apenas nutrir a criança; envolve uma profunda interação entre mãe e filho. É uma estratégia que promove o vínculo, o afeto, a proteção e a nutrição do bebê; e de forma sensível, econômica e eficaz auxilia na redução da morbimortalidade infantil. O aleitamento materno (AM) é preconizado pela Organização Mundial de Saúde (OMS) e pelo Ministério da Saúde (MS), de forma exclusiva nos primeiros seis meses de vida e complementado por até dois anos ou mais (BRASIL, 2015). De acordo com a Iniciativa Hospital Amigo da Criança (IHAC), passo quatro, é importante auxiliar as mães a iniciar o aleitamento na primeira meia hora de vida após o nascimento (BRASIL, 2011).

$\mathrm{O}$ ato de colocar o recém-nascido (RN) para mamar imediatamente após o parto encoraja e incentiva as mães a compreenderem a importância de amamentar (NETTO et al., 2016). A amamentação na sala de parto possibilita ao RN uma melhor adaptação da vida extrauterina, a regulação glicêmica, cardiorrespiratória e térmica (SILVA, J. L. P. et al., 2018). A Rede Brasileira de Bancos de Leite Humano (2020) complementa que, no contato pele a pele, o toque do corpo do bebê sobre o da mãe e sobre o seio materno, estimula na mulher a liberação da ocitocina favorecendo a descida do leite.

Segundo o MS, o leite materno pode evitar 13\% das mortes por causas preveníveis em crianças menores de cinco anos (FREITAS; WERNECK, BORIM, 2018). Segundo a Organização Pan-Americana da Saúde (OPAS), 5 em cada 20 bebês na América Latina e Caribe não são amamentados na primeira hora de vida. Em 2017, estima-se que 78 milhões de RN no mundo tiveram que esperar mais de uma hora para serem colocados no peito de suas mães (OPAS/OMS, 2019). Na última década, dentre os 106 milhões de bebês que nasceram a cada ano, apenas 50 milhões foram privilegiados pelo aleitamento materno exclusivo (AME) (ALVES et al., 2016).

Os dados do MS em 2008 mostravam que o índice de bebês que mamaram na primeira hora de vida em hospitais Amigo da Criança era de 71,9\% e de 65,6\% em outras maternidades. Apesar de pequena a diferença (6,3\%), ela revela que aproximadamente 190000 crianças estão sendo beneficiadas desta prática (COFEN, 2010). No Brasil, atualmente, apenas 57,3\% das crianças são amamentadas por 24 meses e 42,9\% se beneficiam do AME até o sexto mês de vida (SILVA, M. F. F. S. Et al., 2018). Em uma pesquisa ainda mais recente encomendada pelo MS foi evidenciado que $45,7 \%$ das crianças brasileiras com menos de seis meses recebem AME. No estudo foram avaliadas 14505 crianças menores de cinco anos entre fevereiro e março de 2020 (COFEN, 2020). 
A interrupção ou continuidade da amamentação está relacionada a fatores biológicos, socioeconômicos e culturais (DOMINGUEZ et al., 2017). O desmame precoce aumenta a morbimortalidade infantil, e compromete o crescimento e desenvolvimentos das crianças, principalmente em populações de baixa condição socioeconômica. É um problema de saúde pública, sendo que é crescente o número de mães que optam por outros tipos de alimentos. Cabe ao enfermeiro estar preparado para atuar diante das dificuldades (MARTINS et al., 2018).

O acompanhamento pré-natal, no âmbito da atenção básica, é um momento ímpar para o estímulo ao AM (SILVA, D. D. et al., 2018). A promoção do AM precoce deve ser iniciada no pré-natal e o enfermeiro precisa identificar os conhecimentos da gestante acerca da amamentação, as experiências, as práticas e vivências social e familiar (FASSARELLA et al., 2018). Deve ainda conhecer os planos das gestantes referentes à amamentação, seus medos e preocupações, os mitos e fantasias, e principalmente orientar sobre a importância e vantagens do AM, e desvantagens de outros alimentos (SILVA, A. M. et al., 2018).

O AM na primeira hora de vida é considerado um indicador de excelência da amamentação. No contexto da sala de parto, o enfermeiro atuará estimulando os demais profissionais de saúde presentes; sensibilizando, informando e integrando os programas de incentivo, promoção e apoio à amamentação na primeira hora de vida (SILVA, J. L. P. et al., 2018). Em 2019, no lançamento da campanha de amamentação o ministro da saúde destacou o determinante papel da enfermagem na primeira hora, considerada a hora de ouro para os $\mathrm{RN}$; e a enfermeira representante do conselho no evento, Fátima Sampaio, concorda que a presença da enfermagem nos primeiros momentos de vida deve ser reconhecida e valorizada (COFEN, 2019).

O enfermeiro deve contribuir para o fortalecimento de sua prática profissional no manejo da amamentação, pois a formação da enfermagem engloba a perspectiva do processo de cuidar, que está ligada ao cuidado de saúde que perpassa pelas estratégias de orientação no processo de amamentar (COSTA et al., 2018).

A interação do enfermeiro com a puérpera é relevante para o apoio e incentivo e manejo clínico do AM. Ao sanar as dúvidas e dificuldades, simular a técnica de amamentar e informar a importância do AM, o enfermeiro adquire a confiança da mulher e contribui para sua confiança e autoestima referentes à prática de amamentação (MERCADO et al., 2017).

Compreende-se assim que a enfermagem desfruta de diversas estratégias para incentivar o AM no puerpério imediato, sejam elas relacionadas à educação em saúde ou no vínculo alcançado no 
acolhimento (FASSARELLA et al., 2018). Neste contexto, buscou-se destacar a prática do enfermeiro como um facilitador da mamada precoce na sala de parto, momento esse potencializado quando o mesmo atua desde o pré-natal até o acompanhamento puerperal, o que justifica a relevância deste estudo.

A motivação para a escolha do tema surgiu a partir das vivências e experiências nas práticas profissionais exercidas em maternidades, nas salas de parto, como técnicas em enfermagem e doula. Percebemos e experienciamos a mamada na primeira hora de vida como positiva para o sucesso da amamentação.

Desta forma, o objetivo do estudo é evidenciar as contribuições do enfermeiro na primeira hora de vida e para tal baseou-se na questão norteadora: Como o enfermeiro contribui com a amamentação na primeira hora de vida do recém- nascido?

Esse estudo trata-se de uma revisão bibliográfica da literatura do tipo integrativa. Foram atendidas as seis etapas da metodologia: 1) identificação do tema e seleção da questão norteadora, 2) estabelecimento dos critérios de inclusão, amostra e buscas, 3) definição de informações a serem extraídas dos artigos selecionados e categorização dos estudos, 4) avaliação dos artigos, 5) interpretação dos resultados e por fim 6) apresentação da síntese do conhecimento científico (MARTINS, 2018).

O levantamento das publicações foi realizado durante o mês de setembro de 2020 através do acesso eletrônico das seguintes bases: Sistema Latino Americano e do Caribe de Informação em Ciências da Saúde (LILACS), Banco de Dados em Enfermagem (BDenf) e Scientific Electronic Library Online (SciELO). Para a identificação e seleção das publicações, foram utilizados os descritores em português cadastrados nos Descritores em Ciências de Saúde (DeCS): Aleitamento Materno; Assistência de enfermagem; Parto Humanizado; Saúde Materno-infantil; Alojamento Conjunto; Desmame Precoce, que foram combinados através do conector booleano "AND". As combinações constam na Tabela 1, com as pesquisas sendo realizadas igualmente nas três bases de dados. 
Tabela 1: Combinações dos descritores para busca dos artigos nas bases de dados

\section{DeCS}

Aleitamento Materno "AND" Assistência de Enfermagem "AND" Saúde Maternoinfantil

\begin{tabular}{|c|}
\hline $\begin{array}{l}\text { Saúde Materno-Infantil, Alojamento Conjunto e Desmame Precoce } \\
\text { Aleitamento Materno "AND" Assistência de enfermagem "AND" Parto Humanizado }\end{array}$ \\
\hline Saúde Materno-infantil “AND" Alojamento Conjunto "AND" Desmame Precoce \\
\hline $\begin{array}{l}\text { Aleitamento Materno “AND” Alojamento Conjunto “AND” Assistência de } \\
\text { Enfermagem }\end{array}$ \\
\hline Aleitamento Materno "AND" Assistência de enfermagem "AND" Desmame Precoce \\
\hline Parto Humanizado “AND” Saúde Materno-infantil “AND” Alojamento Conjunto \\
\hline Aleitamento Materno "AND" Saúde Materno-infantil “AND” Parto Humanizado \\
\hline Aleitamento Materno "AND” Desmame Precoce "AND" Alojamento Conjunto \\
\hline
\end{tabular}

Fonte: As autoras, 2020.

Os critérios definidos para a busca em todas as bases de dados foram: artigos que destacassem a importância da amamentação precoce na primeira hora de vida, associada à atuação dos enfermeiros; publicados nos últimos cinco anos (2015 a 2020); idioma português, textos disponíveis gratuíta e integralmente onlie. Foram utilizados também documentos oficiais como: Cadernos do Ministério da Saúde (Saúde da Criança e IHAC); dados coletados em sites oficiais como: Organização Pan-Americana da Saúde/Organização Mundial da Saúde (OPAS/OMS), Conselho Federal de Enfermagem (COFEN) e da Rede Brasileira de Bancos de Leite Humano; artigos produzidos no Brasil.

Foram excluídas publicações anteriores a 2015; artigos que não respondiam à questão norteadora da pesquisa; artigos publicados apenas em inglês ou espanhol; indisponíveis na íntegra; desassociados com a área de enfermagem e artigos que não abordassem os objetivos do tema pesquisado.

Através do cruzamento dos descritores o número total de artigos encontrados nas três bases de dados, de acordo com a Figura 1, foi de 66 artigos. Aplicando os critérios de inclusão e exclusão, foram selecionados 30 artigos, sendo 05 (16,6\%) publicações da base de dados LILACS, 13 (43,3\%) publicações da base de dados BDenf e 12 (40\%) publicações da base de dados SciELO. 
Figura 1: Diagrama do resultado da aplicação dos critérios de inclusão e exclusão

\begin{tabular}{|c|c|}
\hline $\begin{array}{c}\text { Cruzamentos dos DeCS nas bases } \\
\text { de dados: } \\
\text { LILACS; BDenf; SciELO }\end{array}$ & \multirow{2}{*}{$\begin{array}{c}\text { Artigos selecionados: } 54 \text { artigos } \\
\text { no total, sendo: } \\
\text { LILACS: } 15 \text { artigos } \\
\text { BDenf: } 26 \text { artigos } \\
\text { SciELO: } 13 \text { artigos }\end{array}$} \\
\hline $\begin{array}{l}\text { Total de estudos encontrados nas } \\
\text { bases de dados: } 66 \text { no total, sendo: } \\
\text { LILACS: } 20 \text { artigos } \\
\text { BDenf: } 32 \text { artigos } \\
\text { SciElo: } 14 \text { artigos }\end{array}$ & \\
\hline & $\downarrow$ \\
\hline Leitura dos Resumos & Leitura na Integra \\
\hline $\begin{array}{c}\text { Estudos excluídos por não } \\
\text { atenderem aos critérios de inclusão e } \\
\text { à questão norteadora: } 12 \text { no total, } \\
\text { sendo: } \\
\text { LILACS: } 05 \text { artigos } \\
\text { BDenf: } 06 \text { artigos } \\
\text { SciELO: } 01 \text { artigo }\end{array}$ & $\begin{array}{c}\text { Artigos incluídos na revisão: } 30 \\
\text { no total, sendo: } \\
\text { LILACS: } 05 \text { artigos } \\
\text { BDenf: } 13 \text { artigos } \\
\text { SciELO: } 12 \text { artigos }\end{array}$ \\
\hline
\end{tabular}

Fonte: As autoras, 2020.

\section{DESENVOLVIMENTO}

A partir da análise dos dados coletados, os 30 artigos selecionados foram organizados no Microsoft Office Word 2010 por: autores, periódico, ano, título, objetivos e resultados dos estudos, de acordo com o Quadro 1, para facilitar a análise dos artigos. Os resultados foram interpretados e discutidos com a finalidade de atingir o objetivo proposto deste estudo, e contribuir cientificamente para a prática clínica da enfermagem. 
Quadro 1: Síntese dos periódicos selecionados para a revisão bibliográfica

\begin{tabular}{|c|c|c|c|}
\hline $\begin{array}{c}\text { Autores/ } \\
\text { Periódico/An } \\
0\end{array}$ & Título & Objetivo & Resultados \\
\hline $\begin{array}{l}\text { FREITAS; } \\
\text { WERNECK; } \\
\text { BORIM, } \\
2018 .\end{array}$ & $\begin{array}{l}\text { Aleitamento } \\
\text { Materno } \\
\text { Exclusivo: }\end{array}$ & $\begin{array}{l}\text { Conhecer a taxa } \\
\text { de adesão ao AME } \\
\text { e as dificuldades }\end{array}$ & $\begin{array}{l}\text { O AME até os seis } \\
\text { meses de vida é } \\
\text { importante em função }\end{array}$ \\
\hline $\begin{array}{l}\text { Revista de } \\
\text { Enfermagem } \\
\text { UFPE online. }\end{array}$ & $\begin{array}{l}\text { Adesão } \\
\text { Dificuldades. }\end{array}$ & $\begin{array}{l}\text { que levam ao } \\
\text { desmame precoceem } \\
\text { um hospital em São } \\
\text { José do Rio Preto. }\end{array}$ & $\begin{array}{l}\text { dos seus benefícios àsaúde } \\
\text { da criança e materna e à } \\
\text { redução } \\
\text { morbimortalidade infantil. } \\
\text { As dificuldades de adesão } \\
\text { referidas pelas mães } \\
\text { fornecem } \\
\text { informações para que a } \\
\text { equipe promova ações de } \\
\text { incentivo à prática do } \\
\text { AME. }\end{array}$ \\
\hline $\begin{array}{l}\text { SILVA, A. M. et } \\
\text { al., } 2018 . \\
\text { Revista de } \\
\text { Enfermagem } \\
\text { UFPE online. }\end{array}$ & $\begin{array}{l}\text { Aleitamento } \\
\text { Materno } \\
\text { Exclusivo: } \\
\text { Empecilhos } \\
\text { Apresentados } \\
\text { por Primíparas. }\end{array}$ & $\begin{array}{l}\text { Identificar os } \\
\text { empecilhos } \\
\text { apresentados pelas } \\
\text { primíparasdas } \\
\text { UBS de } \\
\text { Itambé - PE, em } \\
\text { relação ao } \\
\text { AMEnos } \\
\text { primeiros } 6 \\
\text { meses de vida. }\end{array}$ & $\begin{array}{l}\text { Percebe-se que } \\
\text { es } \\
\text { empecilhos abordados } \\
\text { podem contribuir para a } \\
\text { elaboração } \\
\text { intervenções e métodos } \\
\text { estratégicos para auxiliara } \\
\text { mulher no momento da } \\
\text { amamentação, } \\
\text { principalmente } \\
\text { primíparas. }\end{array}$ \\
\hline $\begin{array}{l}\text { NETTO et al., } \\
2016 . \\
\text { Ciência, Cuidado } \\
\text { \& Saúde. }\end{array}$ & \begin{tabular}{lr}
\multicolumn{2}{l}{ Amamentação na } \\
\multicolumn{2}{r}{ Primeira } \\
Hora de & Vida \\
em & uma \\
Instituição & com \\
Iniciativa & \\
Hospital Amigo \\
da Criança.
\end{tabular} & $\begin{array}{l}\text { Identificar } \\
\text { prevalência da } \\
\text { amamentação na } \\
\text { primeira hora devida } \\
\text { em uma instituição } \\
\text { com IHAC em Foz } \\
\text { do Iguaçu }- \text { PR, e } \\
\text { seus resultados } \\
\text { para a } \\
\text { manutenção doAM. }\end{array}$ & $\begin{array}{l}\text { Os RN que iniciaram a } \\
\text { mamada antes de uma hora } \\
\text { demonstraram melhor } \\
\text { adaptação da } \\
\text { sucção } \\
\text { quando } \\
\text { comparados aos que não } \\
\text { mamaram na primeira hora } \\
\text { de vida. Destaca-se a } \\
\text { responsabilidade } \\
\text { enfermagem } \\
\text { garantir à mãe e ao RN o } \\
\text { direito à amamentaçãona } \\
\text { primeira hora de vida, } \\
\text { assim como para dar } \\
\text { seguimento ao AM após a } \\
\text { alta hospitalar. }\end{array}$ \\
\hline
\end{tabular}




\begin{tabular}{|c|c|c|c|}
\hline $\begin{array}{l}\text { COSTA et al., } \\
2018 . \\
\text { Revista Online } \\
\text { de Pesquisa } \\
\text { (Universidade } \\
\text { Federal do } \\
\text { Estado do Rio de } \\
\text { Janeiro, Online). }\end{array}$ & $\begin{array}{l}\text { Atuação do } \\
\text { Enfermeiro no } \\
\text { Manejo Clínico } \\
\text { da Amamentação: } \\
\text { Estratégias parao } \\
\text { Aleitamento } \\
\text { Materno. }\end{array}$ & 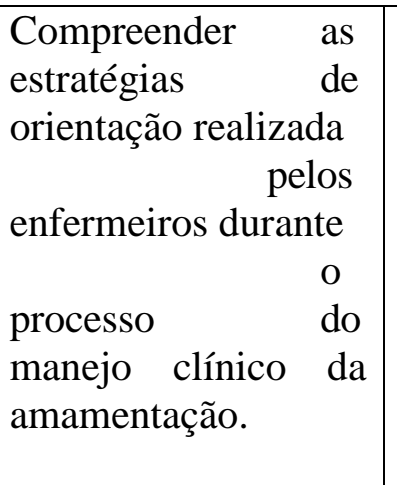 & $\begin{array}{l}\text { Os enfermeiros possuemo } \\
\text { entendimento das } \\
\text { estratégias do manejo } \\
\text { clínico da amamentação, } \\
\text { tais como ações de apoioà } \\
\text { mulher com ênfase na } \\
\text { atenção humanizada e não } \\
\text { sistematizada, } \\
\text { focando sua assistência na } \\
\text { forma de orientações. }\end{array}$ \\
\hline $\begin{array}{c}\text { Autores/ } \\
\text { Periódico/Ano }\end{array}$ & Título & Objetivo & Resultados \\
\hline $\begin{array}{l}\text { SILVA, M. F. F. } \\
\text { S. et al., } 2018 . \\
\text { Revista Rene. }\end{array}$ & $\begin{array}{l}\text { Autoeficácia em } \\
\text { Amamentação e } \\
\text { Fatores } \\
\text { Interligados. }\end{array}$ & $\begin{array}{l}\text { Verificar a } \\
\text { apresentação da } \\
\text { autoeficácia materna } \\
\text { relacionada à } \\
\text { amamentação entre } \\
\text { puérperas }\end{array}$ & $\begin{array}{l}\text { As participantes doestudo } \\
\text { apresentaram escore alto } \\
\text { para } \\
\text { autoeficácia } \\
\text { mamamentar relacionado } \\
\text { aplanejamento } \\
\text { da gravidez, orientações } \\
\text { recebidas durante o pré- } \\
\text { natal, via de partovaginal, } \\
\text { tempo para a primeira } \\
\text { sucção antes da primeira } \\
\text { hora de vida,não oferecer } \\
\text { à criança outros leites } \\
\text { antes da apojadura, } \\
\text { conhecimento da mãe } \\
\text { sobre tempo mínimo de } \\
\text { AME e o não uso de } \\
\text { drogas ilícitas. }\end{array}$ \\
\hline $\begin{array}{l}\text { MARTINS et al., } \\
2018 . \\
\text { Revista de } \\
\text { Enfermagem UFPE } \\
\text { online. }\end{array}$ & $\begin{array}{l}\text { Conhecimento de } \\
\text { Sutrizes } \\
\text { Sobre } \\
\text { Aleitamento } \\
\text { Materno: } \\
\text { Contribuições da } \\
\text { Enfermagem. }\end{array}$ & \begin{tabular}{l} 
Descrever o \\
conhecimento e as \\
dúvidas de \\
nutrizes sobre o \\
aleitamento materno \\
no AC deum \\
\multicolumn{1}{c}{ hospital em } \\
Rio das Ostras - RJ.
\end{tabular} & $\begin{array}{l}\text { Percebeu-se déficit no } \\
\text { conhecimento } \\
\text { de } \\
\text { nutrizes sobre o AM, oque } \\
\text { demostra ser necessário } \\
\text { investimento em } \\
\text { s educativas dialógicas } \\
\text { que possibilitem ao } \\
\text { enfermeiro reconheceras } \\
\text { dúvidas maternas para a } \\
\text { promoção de apoio e } \\
\text { orientação efetivos. }\end{array}$ \\
\hline
\end{tabular}




\begin{tabular}{|c|c|c|c|}
\hline $\begin{array}{l}\text { MERCADO et } \\
\text { al., } 2017 .\end{array}$ & $\begin{array}{l}\text { Cuidados e } \\
\text { Orientações de } \\
\text { Enfermagem às }\end{array}$ & $\begin{array}{rr}\text { Verificar } & \text { as } \\
\text { orientações prestadas } & \text { pelo }\end{array}$ & $\begin{array}{ll}\text { A assistência } & \text { de } \\
\text { enfermagem } & \text { às }\end{array}$ \\
\hline $\begin{array}{l}\text { Revista de } \\
\text { Enfermagem UFPE } \\
\text { online. }\end{array}$ & $\begin{array}{l}\text { Puérperas no } \\
\text { Alojamento } \\
\text { Conjunto. }\end{array}$ & $\begin{array}{ll}\text { enfermeiro } & \text { à } \\
\text { puérpera } & \text { em } \\
\text { Alojamento } & \\
\text { Conjunto (AC). } & \end{array}$ & $\begin{array}{l}\text { puérperas no AC está } \\
\text { voltada às orientações } \\
\text { quanto ao autocuidado e } \\
\text { cuidados com o RN. OAC } \\
\text { apresenta, como uma de } \\
\text { suas vantagens, o } \\
\text { oferecimento } \\
\text { condições à equipe de } \\
\text { enfermagem } \\
\text { rapromover o treinamento } \\
\text { materno, através de } \\
\text { demonstrações práticas. }\end{array}$ \\
\hline $\begin{array}{c}\text { Autores/ } \\
\text { Periódico/Ano }\end{array}$ & Título & Objetivo & Resultados \\
\hline $\begin{array}{l}\text { DOMINGUEZ et } \\
\text { al., } 2017 . \\
\text { Revista } \\
\text { Enfermagem } \\
\text { UERJ. }\end{array}$ & $\begin{array}{l}\text { Dificuldades do } \\
\text { Estabeleciment o } \\
\text { Amamentação: da } \\
\text { Visão das } \\
\text { Enfermeiras } \\
\text { Atuantes nas } \\
\text { Unidades Básicas } \\
\text { Saúde. }\end{array}$ & $\begin{array}{l}\text { Conhecer, sob aótica } \\
\text { das } \\
\text { enfermeiras das UBS } \\
\text { da zona urbana do } \\
\text { município do Rio } \\
\text { Grande - RS, as } \\
\text { dificuldades para o } \\
\text { estabelecimento do } \\
\text { AM. }\end{array}$ & $\begin{array}{l}\text { As crenças } \\
\text { dacomunidade, } \\
\text { desatualização } \\
\text { profissional e a técnica } \\
\text { inadequada, } \\
\text { exercem } \\
\text { influência nas condutas } \\
\text { relacionadas } \\
\text { à } \\
\text { amamentação. } \\
\text { É necessário o apoio } \\
\text { profissional por parte do } \\
\text { sistema de saúde para } \\
\text { fortalecimento e apoio } \\
\text { nos desafios de diminuir } \\
\text { os índices de desmame } \\
\text { precoce. }\end{array}$ \\
\hline 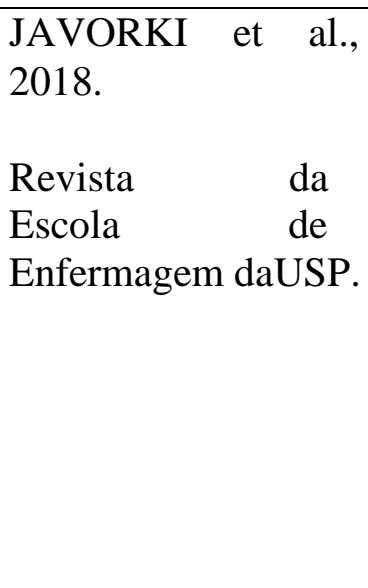 & $\begin{array}{l}\text { Efeitos de uma } \\
\text { tecnologia } \\
\text { educativa na } \\
\text { autoeficácia para } \\
\text { amamentare na } \\
\text { prática do } \\
\text { aleitamento } \\
\text { materno } \\
\text { exclusivo. }\end{array}$ & \begin{tabular}{l} 
Avaliar os efeitosda \\
utilização, no \\
pré-natal, de um \\
álbum seriado na \\
autoeficácia materna \\
\multicolumn{2}{c}{ para } \\
amamentar e a \\
repercussão desta \\
intervenção no \\
AME nos primeiros \\
2 meses de vidada \\
criança.
\end{tabular} & $\begin{array}{l}\text { O uso de uma tecnologia } \\
\text { educacional, pautada no } \\
\text { conceito da autoeficácia } \\
\text { para amamentar, écapaz } \\
\text { de elevar os escores da } \\
\text { autoeficácia para } \\
\text { amamentar, e o aumento } \\
\text { desses escores repercute } \\
\text { positivamente na } \\
\text { incidência do AME em } \\
\text { curto prazo. }\end{array}$ \\
\hline
\end{tabular}




\begin{tabular}{|c|c|c|c|}
\hline $\begin{array}{l}\text { ALVES et al., } \\
2016 . \\
\text { Escola Anna } \\
\text { Nery [online]. }\end{array}$ & $\begin{array}{l}\text { Manejo Clínico } \\
\text { da Amamentação: } \\
\text { Valorização } \\
\text { Axiológica sob a } \\
\text { Ótica da } \\
\text { Mulher-Nutriz. }\end{array}$ & $\begin{array}{l}\text { Analisar a } \\
\text { valorização } \\
\text { axiológica da } \\
\text { mulher-nutriz quanto } \\
\text { ao manejoclínico da } \\
\text { amamentação. }\end{array}$ & $\begin{array}{l}\text { O manejo } \\
\text { da amamentação } \\
\text { possibilita cuidados em } \\
\text { saúde que extrapolam } \\
\text { interesses, intenções e } \\
\text { pontos de vista de } \\
\text { profissionais e instituição } \\
\text { de saúde; questões } \\
\text { humanas e existenciais } \\
\text { devem ser apreendidas } \\
\text { experiências racionais. } \\
\text { Essa percepção propicia } \\
\text { ressignificar } \\
\text { a assistência centrada na } \\
\text { mulher, na criança e na } \\
\text { família. }\end{array}$ \\
\hline $\begin{array}{c}\text { Autores/ } \\
\text { Periódico/Ano }\end{array}$ & Título & Objetivo & Resultados \\
\hline $\begin{array}{l}\text { CASTRO et al., } \\
2019 \\
\text { Revista } \\
\text { Enfermagem } \\
\text { UERJ. }\end{array}$ & $\begin{array}{ll}\text { Partejar } & \text { de } \\
\text { Primíparas: } & \\
\text { reflexos } & \text { na } \\
\text { amamentação. } & \end{array}$ & $\begin{array}{l}\text { Analisar, a partir } \\
\text { da experiência de } \\
\text { primíparas, a } \\
\text { relação entre a } \\
\text { assistência recebida } \\
\text { durante oparto } \\
\text { normal e opós-parto } \\
\text { imediatoe seus } \\
\text { reflexos na } \\
\text { amamentação. }\end{array}$ & $\begin{array}{l}\text { Os anseios } \\
\text { eparticularidades de cada } \\
\text { puérpera precisam ser } \\
\text { respeitados e atendidos, } \\
\text { valorizando } \\
\text { o investimento em } \\
\text { políticas de saúde que } \\
\text { enfatizem o cuidado. A } \\
\text { educação em saúde } \\
\text { precisa estabelecer } \\
\text { reflexão, discussão e } \\
\text { aprendizado nesse } \\
\text { processo. Não sãoapenas } \\
\text { orientações técnicas de } \\
\text { forma rápida e única que } \\
\text { as puérperas necessitam, } \\
\text { mas de apoio e } \\
\text { compreensão. }\end{array}$ \\
\hline
\end{tabular}




\begin{tabular}{|c|c|c|c|}
\hline $\begin{array}{l}\text { SILVA, D. D. etal., } \\
2018 . \\
\text { REME - } \\
\text { Mineira } \\
\text { Enfermagem. }\end{array}$ & $\begin{array}{l}\text { Promoção do } \\
\text { Aleitamento } \\
\text { Materno no Pré- } \\
\text { Natal: Discurso } \\
\text { das Gestantes e } \\
\text { dos Profissionais } \\
\text { deSaúde. }\end{array}$ & $\begin{array}{l}\text { Analisar o discursode } \\
\text { gestantes } \\
\text { profissionais sobreas } \\
\text { orientaçõesacerca do } \\
\text { AM fornecidas } \\
\text { durante o pré-natal na } \\
\text { rede básica de saúde } \\
\text { em Florianópolis - } \\
\text { SC. }\end{array}$ & $\begin{array}{l}\text { São } \\
\text { sestratégias } \\
\text { necessária } \\
\text { metodologias ativas euso } \\
\text { de redes sociais durante o } \\
\text { pré-natal a fim de } \\
\text { fomentar a promoção do } \\
\text { aleitamento materno, } \\
\text { garantir a segurança } \\
\text { materna e alavancar as } \\
\text { taxas prevalência de } \\
\text { aleitamento materno no } \\
\text { município. }\end{array}$ \\
\hline $\begin{array}{l}\text { FASSARELLA et } \\
\text { al., } 2018 . \\
\text { Revista Nursing. }\end{array}$ & $\begin{array}{ll}\text { Percepção } & \text { da } \\
\text { Equipe } & \text { de } \\
\text { Enfermagem } & \\
\text { Frente } & \text { ao } \\
\text { Aleitamento } & \\
\text { Materno: do } & \\
\text { conhecimento à } \\
\text { implementação. }\end{array}$ & 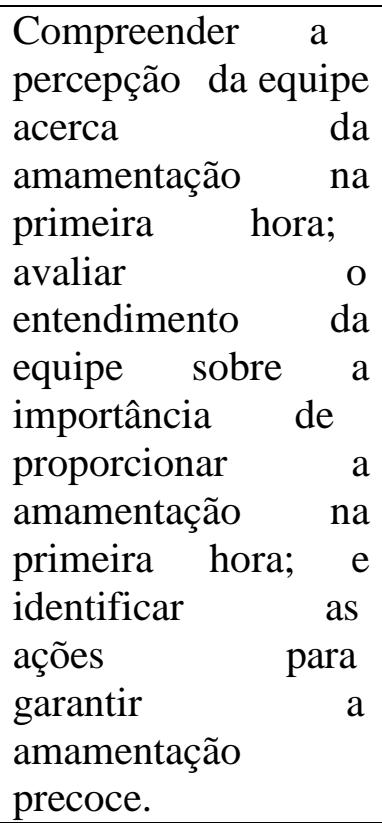 & $\begin{array}{l}\text { Conclui-se que algumas } \\
\text { barreiras } \\
\text { ão } \\
\text { encontradas } \\
\text { or profissionais quanto à } \\
\text { aceitação das puérperas } \\
\text { acerca do AM o querevela } \\
\text { a necessidade de uma } \\
\text { sistematização por parte } \\
\text { da equipe com ações } \\
\text { educativas sob atemática. }\end{array}$ \\
\hline $\begin{array}{c}\text { Autores/ } \\
\text { Periódico/Ano }\end{array}$ & Título & Objetivo & Resultados \\
\hline $\begin{array}{l}\text { JESUS; } \\
\text { OLIVEIRA; } \\
\text { MORAES, } 2017 . \\
\text { Ciência \& Saúde } \\
\text { Coletiva. }\end{array}$ & $\begin{array}{l}\text { Capacitação de } \\
\text { Profissionais de } \\
\text { Saúde em } \\
\text { Aleitamento } \\
\text { Materno e sua } \\
\text { Associação com } \\
\text { Conhecimentos, } \\
\text { Habilidades e } \\
\text { Práticas. }\end{array}$ & $\begin{array}{lr}\text { Analisar a associa- } \\
\text { ção entre } \\
\text { capacitação a } \\
\text { AM em } \\
\text { conhecimentos, } & \text { os } \\
\text { habilidades e } & \text { as } \\
\text { práticas } & \text { de } \\
\text { profissionais desaúde } \\
\text { que atuam } & \text { na } \\
\text { assistência } & \text { a } \\
\text { gestantes, mães } & \text { e } \\
\text { bebês } & \text { em } \\
\text { hospitais. } & \end{array}$ & $\begin{array}{l}\text { Conclui- } \\
\text { se que } \\
\text { acapacitação contribu } \\
\text { ipara o aprimoramento de } \\
\text { conhecimentos, } \\
\text { habilidades e práticas em } \\
\text { aleitamento } \\
\text { ' materno } \\
\text { fundamentais } \\
\text { àassistência } \\
\text {-infantil. }\end{array}$ \\
\hline
\end{tabular}




\begin{tabular}{|c|c|c|c|}
\hline $\begin{array}{l}\text { COCA et al., } \\
2018 . \\
\text { Revista Paulistade } \\
\text { Pediatria. }\end{array}$ & $\begin{array}{ll}\text { Conjunto de } & \text { de } \\
\text { Medidas para } & \text { o } \\
\text { Incentivo } & \text { do } \\
\text { Aleitamento } & \\
\text { Materno } & \\
\text { Exclusivo Intra- } \\
\text { hospitalar: } \\
\text { evidências de } \\
\text { revisões } \\
\text { sistemáticas. }\end{array}$ & $\begin{array}{l}\text { Identificar } \\
\text { principais } \\
\text { recomendações } \\
\text { encontradas } \\
\text { em revisões } \\
\text { sistemáticas } \\
\text { relacionadas aos } \\
\text { fatores } \\
\text { proteção } \\
\text { do AME intra- } \\
\text { hospitalar. }\end{array}$ & $\begin{array}{l}\text { O contato pele a pele } \\
\text { precoce, a permanência } \\
\text { da criança em AC, } \\
\text { aintervenção } \\
\text { na dor } \\
\text { mamilar durante } \\
\text { aamamentação, } \\
\text { restrição do uso } \\
\text { de para } \\
\text { suplementação AM sob } \\
\text { lactentes, o AM } \\
\text { livre e } \\
\text { demanda asintervenções } \\
\text { educativas } \\
\text { meio de } \\
\text { suporte } \\
\text { individual e/ou } \\
\text { em durante } \\
\text { grupos as do } \\
\text { ainternação } \\
\text { foram as } \\
\text { recomendações } \\
\text { encontradas } \\
\text { configuram a proposta do } \\
\text { conjunto de medidas } \\
\text { para o incentivo ao } \\
\text { AME a } \\
\text { intra-hospitalar. }\end{array}$ \\
\hline $\begin{array}{l}\text { ALVES et al., } \\
2018 . \\
\text { Revista Rene. }\end{array}$ & $\begin{array}{l}\text { Contribuições de } \\
\quad \text { Enfermeiros } \\
\text { na Promoção do } \\
\text { Aleitamento } \\
\text { Materno } \\
\text { Exclusivo. }\end{array}$ & $\begin{array}{lc}\text { Identificar } & \text { as } \\
\text { contribuições } & \text { de } \\
\text { enfermeiros na } & \\
\text { promoção } & \text { do } \\
\text { aleitamento materno } \\
\text { exclusivo. }\end{array}$ & $\begin{array}{l}\text { Os } \\
\text { enfermeiros } \\
\text { desempenham papel } \\
\text { relevante noAME, } \\
\text { contribuindo com ações } \\
\text { que transcendem } \\
\text { adimensão } \\
\text { biológica etecnicista, } \\
\text { contemplandoa } \\
\text { singularidade e } \\
\text { ocontexto vivido } \\
\text { damulher/nutriz, } \\
\text { promovendo } \\
\text { educação } \\
\text { em saúde durante o ciclo } \\
\text { gravídico puerperal. }\end{array}$ \\
\hline
\end{tabular}




\begin{tabular}{|c|c|c|c|}
\hline $\begin{array}{c}\text { Autores/ } \\
\text { Periódico/Ano }\end{array}$ & Título & Objetivo & Resultados \\
\hline $\begin{array}{l}\text { SILVA, J. L. P. et } \\
\text { al., } 2018 . \\
\text { Texto Contexto - } \\
\text { Enfermagem. }\end{array}$ & $\begin{array}{l}\text { Fatores } \\
\text { Associados ao } \\
\text { Aleitamento } \\
\text { Materno na } \\
\text { Primeira Hora } \\
\text { de Vida em um } \\
\text { Hospital Amigo } \\
\text { da Criança. }\end{array}$ & $\begin{array}{l}\text { Avaliar os fatores } \\
\text { associados à } \\
\text { prática } \\
\text { aleitamento } \\
\text { materno na } \\
\text { primeira hora pós- } \\
\text { parto no Centro } \\
\text { Obstétrico e AC do } \\
\text { Hospital das } \\
\text { Clínicas de Recife } \\
\text {-PE. }\end{array}$ & $\begin{array}{l}\text { A amamentação, na } \\
\text { primeira hora pós-parto, } \\
\text { ficou aquém do } \\
\text { recomendado pela OMS, } \\
\text { mesmo a instituição } \\
\text { estudada sendo } \\
\text { considerada } \\
\text { Hospital Amigo da } \\
\text { Criança, e, que os } \\
\text { principais fatores } \\
\text { associados a esta prática } \\
\text { foram o parto vaginal, } \\
\text { enfermeiro prestador da } \\
\text { assistência ao parto e o } \\
\text { contato pele a pele entre } \\
\text { mãe e filho. }\end{array}$ \\
\hline $\begin{array}{l}\text { SILVA, L. L. A. et } \\
\text { al., } 2018 . \\
\text { Saúde } \\
\text { Pesquisa. }\end{array}$ & $\begin{array}{lr}\text { Prevalência } & \text { do } \\
\text { Aleitamento } & \\
\text { Materno } & \\
\text { Exclusivo } & \text { e } \\
\text { Fatores } & \text { de } \\
\text { Risco. } & \end{array}$ & $\begin{array}{l}\text { Investigar a } \\
\text { prevalência do } \\
\text { AME e seus } \\
\text { fatores de risco no } \\
\text { período de janeiro } \\
\text { a dezembro de } \\
2015, \text { no AC de um } \\
\text { hospital } \\
\text { público do Piauí. }\end{array}$ & $\begin{array}{l}\text { É importante que as } \\
\text { mães sintam que os pro- } \\
\text { fissionais de saúde estão } \\
\text { aptos para auxiliá-las, } \\
\text { para sentirem-se } \\
\text { apoiadas e confiantes, } \\
\text { sendo necessário reali- } \\
\text { zar intervenções de } \\
\text { promoção ao AM e } \\
\text { prevenção do desmame } \\
\text { precoce por meio de } \\
\text { atividades educativasque } \\
\text { orientem as mães e as } \\
\text { famílias envolvidas nesse } \\
\text { processo. Tirando } \\
\text { dúvidas, esclarecendo } \\
\text { mitos e crenças sobre } \\
\text { amamentar, a fim de que } \\
\text { se sintam assistidas em } \\
\text { suas dúvidas e } \\
\text { dificuldades. }\end{array}$ \\
\hline $\begin{array}{l}\text { SILVA, O. L. O. } \\
\text { et al., } 2018 . \\
\text { Revista Brasileira } \\
\text { de Saúde } \\
\text { Materno Infantil. }\end{array}$ & $\begin{array}{l}\text { A Iniciativa } \\
\text { Hospital Amigo } \\
\text { da Criança: } \\
\text { contribuição } \\
\text { para o } \\
\text { incremento da } \\
\text { amamentação e } \\
\text { a redução da } \\
\text { mortalidade } \\
\text { infantil no Brasil. }\end{array}$ & $\begin{array}{l}\text { Estimar a fração } \\
\text { atribuível } \\
\text { populacional da } \\
\text { mortalidade infantil } \\
\text { evitável mediante } \\
\text { as mudanças em } \\
\text { indicadores de } \\
\text { amamentação no } \\
\text { Brasil devido à } \\
\text { Iniciativa Hospital } \\
\text { Amigo da Criança. }\end{array}$ & $\begin{array}{l}\text { A redução da } \\
\text { mortalidade em crianças } \\
\text { de } 7 \text { a } 180 \text { dias em } 2008 \text {, } \\
\text { potencialmente atribuível } \\
\text { à IHAC através da } \\
\text { promoção de indicadores } \\
\text { de AM, reforça a } \\
\text { importância de fortalecer } \\
\text { e expandir essa iniciativa } \\
\text { no Brasil para aumentara } \\
\text { sobrevivência infantil. }\end{array}$ \\
\hline
\end{tabular}




\begin{tabular}{|c|c|c|c|}
\hline $\begin{array}{c}\text { Autores/ } \\
\text { Periódico/Ano }\end{array}$ & Título & Objetivo & Resultados \\
\hline $\begin{array}{l}\text { LIMA et al., } \\
2019 . \\
\text { Revista Gaúcha } \\
\text { de Enfermagem. }\end{array}$ & $\begin{array}{l}\text { Aleitamento } \\
\text { Materno } \\
\text { Exclusivo de } \\
\text { Prematuros e } \\
\text { Motivos para } \\
\text { sua Interrupção } \\
\text { no Primeiro Mês } \\
\text { Pós-alta } \\
\text { Hospitalar. }\end{array}$ & $\begin{array}{l}\text { Estimar } \\
\text { prevalência de } \\
\text { AME de } \\
\text { prematuros na alta } \\
\text { hospitalar, aos 15e } \\
30 \text { dias pós-alta;e } \\
\text { identificar as } \\
\text { alegações maternas } \\
\text { para a } \\
\text { sua interrupção. }\end{array}$ & $\begin{array}{l}\text { Houve } \\
\text { significativa nas taxas de } \\
\text { AME após a alta, apontando } \\
\text { a importância do } \\
\text { acompanhamento pós-alta } \\
\text { para reduzir o desmame } \\
\text { precoce, } \\
\text { sobretudo com ações } \\
\text { educativas que previnamas } \\
\text { insuficiências reais e } \\
\text { percebidas. É necessárioum } \\
\text { planejamento de alta, que } \\
\text { envolva a equipe } \\
\text { multidisciplinar e a } \\
\text { mãe/família, junto a uma } \\
\text { rede de atenção à saúde } \\
\text { eficiente, com ações } \\
\text { articuladas entre a unidade } \\
\text { hospitalar e o serviço de } \\
\text { atençãobásica. }\end{array}$ \\
\hline $\begin{array}{l}\text { ALMEIDA; } \\
\text {;UED, 2015. } \\
\text { Revista Paulista } \\
\text { de Pediatria. }\end{array}$ & $\begin{array}{l}\text { Apoio ao } \\
\text { Aleitamento } \\
\text { Materno pelos } \\
\text { Profissionais de } \\
\text { Saúde: revisão } \\
\text { integrativa da } \\
\text { literatura. }\end{array}$ & $\begin{array}{lr}\text { Fazer uma revisão da } \\
\text { literatura para avaliar } \\
\text { a prática de } \\
\text { profissionais de } \\
\text { saúde } & \text { na } \\
\text { promoção e } & \text { no } \\
\text { apoio } & \text { à } \\
\text { amamentação. }\end{array}$ & $\begin{array}{l}\text { Os profissionais de } \\
\text { saúde precisam ser bem } \\
\text { capacitados para } \\
\text { trabalhar com a } \\
\text { promoção do AM, sejapor } \\
\text { meio das instituiçõesde } \\
\text { ensino e formação,seja } \\
\text { por gestores da } \\
\text { saúde, a fim de } \\
\text { consolidar equipes } \\
\text { multiprofissionais } \\
\text { comprometidas com a } \\
\text { saúde materno-infantil. }\end{array}$ \\
\hline $\begin{array}{l}\text { CRUZ et al., } \\
2018 . \\
\text { Caderno de } \\
\text { Saúde Coletiva. }\end{array}$ & $\begin{array}{l}\text { Associação entre } \\
\text { o Tipo de } \\
\text { Aleitamento na } \\
\text { Alta Hospitalar } \\
\text { do Recém- } \\
\text { nascido e aos } \\
\text { Seis Meses de } \\
\text { Vida. }\end{array}$ & $\begin{array}{l}\text { Objetivou-se } \\
\text { verificar a } \\
\text { associação entre o } \\
\text { tipo de aleitamentono } \\
\text { momento da alta } \\
\text { hospitalar do RN e a } \\
\text { prática da } \\
\text { amamentação aosseis } \\
\text { meses de vida. }\end{array}$ & $\begin{array}{l}\text { O estudo concluiu que é } \\
\text { importante que, ao deixara } \\
\text { maternidade, o bebê esteja } \\
\text { em AME, pois, dessa forma, } \\
\text { terá } 2,5 \text { vezes mais chances } \\
\text { de manter esse tipo de } \\
\text { aleitamento até os seis } \\
\text { meses de vida. }\end{array}$ \\
\hline
\end{tabular}




\begin{tabular}{|c|c|c|c|}
\hline $\begin{array}{c}\text { Autores/ } \\
\text { Periódico/Ano }\end{array}$ & Título & Objetivo & Resultados \\
\hline $\begin{array}{l}\text { ROCHA G. P. et } \\
\text { al., } 2018 . \\
\text { Caderno de } \\
\text { Saúde Pública. }\end{array}$ & $\begin{array}{l}\text { Condicionantes } \\
\text { da Amamentação } \\
\text { Exclusiva na } \\
\text { Perspectiva } \\
\text { Materna. }\end{array}$ & $\begin{array}{l}\text { O objetivo foi } \\
\text { explorar, entre } \\
\text { nutrizes, } \\
\text { vivências positivas e } \\
\text { negativas } \\
\text { realização } \\
\text { prática } \\
\text { amamentação } \\
\text { exclusiva, } \\
\text { Município } \\
\text { Viçosa-MG. }\end{array}$ & $\begin{array}{l}\text { O estudo possibilitou a } \\
\text { apreensão } \\
\text { dimensões positivas e } \\
\text { negativas ligadas à } \\
\text { amamentação exclusiva e } \\
\text { sugere a importância da } \\
\text { assistência } \\
\text { profissional à mulher na fase } \\
\text { inicial da } \\
\text { amamentação e do apoioda } \\
\text { rede social para amenizar a } \\
\text { sensação de } \\
\text { sobrecarga da mulher. }\end{array}$ \\
\hline $\begin{array}{l}\text { SACO et al., } \\
2019 . \\
\text { Texto e Contexto } \\
\text { Enfermagem. }\end{array}$ & $\begin{array}{l}\text { Contato Pele a } \\
\text { Pele e Mamada } \\
\text { Precoce: fatores } \\
\text { associados e } \\
\text { influência no } \\
\text { aleitamento } \\
\text { materno. }\end{array}$ & $\begin{array}{l}\text { Verificar os } \text { fatores } \\
\text { associados } \\
\text { prática do contato } \\
\text { pele a pele com } \\
\text { amamentação } \\
\text { primeira hora } \\
\text { de vida e sua } \\
\text { influência no AME } \\
\text { no primeiro mês. }\end{array}$ & $\begin{array}{l}\text { As boas condições de } \\
\text { nascimento da criançaforam } \\
\text { fatores protetores para a } \\
\text { realização do contato pele a } \\
\text { pele com amamentação na } \\
\text { primeira hora, enquanto a } \\
\text { menor idade materna e os } \\
\text { partos cirúrgicos } \\
\text { demonstraram-se como } \\
\text { fatores de risco. O AME no } \\
\text { primeiro mês de vida da } \\
\text { criança não esteve associado } \\
\text { ao contato e amamentação } \\
\text { precoce. }\end{array}$ \\
\hline $\begin{array}{l}\text { BARBOSA et al., } \\
2018 . \\
\text { Revista Brasileira } \\
\text { de Saúde } \\
\text { Materno Infantil. }\end{array}$ & \begin{tabular}{lr}
\multicolumn{2}{l}{ Dificuldades } \\
Iniciais com a \\
Técnica & da \\
Mamada & $\mathrm{e}$ \\
Impacto & na \\
Duração do & \\
Aleitamento & \\
Materno & \\
Exclusivo. &
\end{tabular} & $\begin{array}{lr}\text { Avaliar a influência } \\
\text { das } & \text { dificuldades } \\
\text { iniciais } & \text { para } \\
\text { amamentar sobre a } & \text { duração do AME. }\end{array}$ & $\begin{array}{l}\text { Aspectos socioeconômicos } \\
\text { dificuldades e } \\
\text { amamentar relacionadasa } \\
\text { problemas com a } \\
\text { mamada } \\
\text { mostraram-se puerperal } \\
\text { fatores que restringem a } \\
\text { duração do AME. É } \\
\text { importante que os } \\
\text { profissionais sejam } \\
\text { habilitados para orientar } \\
\text { adequadamente sobre a } \\
\text { técnica da mamada, } \\
\text { corrigindo problemas e } \\
\text { orientando para a } \\
\text { resolução de dificuldades } \\
\text { com as mamadas } \\
\text { puerperais. }\end{array}$ \\
\hline
\end{tabular}




\begin{tabular}{|c|c|c|c|}
\hline $\begin{array}{c}\text { Autores/ } \\
\text { Periódico/Ano }\end{array}$ & Título & Objetivo & Resultados \\
\hline $\begin{array}{l}\text { GASPARIN et } \\
\text { al., } 2020 . \\
\text { Revista Gaúcha } \\
\text { de Enfermagem. }\end{array}$ & $\begin{array}{l}\text { Fatores } \\
\text { Associados à } \\
\text { Manutenção do } \\
\text { Aleitamento } \\
\text { Materno } \\
\text { Exclusivo no } \\
\text { Pós-parto tardio. }\end{array}$ & $\begin{array}{lr}\text { Identificar } & \text { os } \\
\text { fatores associados à } \\
\text { manutenção do AME } \\
\text { e verificar a } \\
\text { justificativa para } \\
\text { introdução de outros } \\
\text { líquidos nopós-parto } \\
\text { tardio, de mães e } \\
\text { crianças atendidaspor } \\
\text { consultor em AM. }\end{array}$ & $\begin{array}{l}\text { O parto vaginal, a não } \\
\text { utilização de chupeta ou } \\
\text { mamadeira e a busca por } \\
\text { ajuda profissional após a alta } \\
\text { se associaram a ma- } \\
\text { nutenção do AME no pós- } \\
\text { parto tardio. A inserção de } \\
\text { umprofissional consultor em } \\
\text { aleitamento materno tem } \\
\text { relevante importância na } \\
\text { ascensão das taxas de } \\
\text { AME. }\end{array}$ \\
\hline $\begin{array}{l}\text { SILVA et al., } \\
2016 . \\
\\
\text { Revista } \\
\text { Nutrição. }\end{array}$ & $\begin{array}{l}\text { Fatores } \\
\text { Associados ao } \\
\text { Contato Pele a } \\
\text { Pele entre } \\
\text { Mãe/filho e } \\
\text { Amamentação na } \\
\quad \text { Sala de } \\
\text { Parto. }\end{array}$ & $\begin{array}{l}\text { Investigar fatores } \\
\text { associados aocontato } \\
\text { pele a peleentre mãe } \\
\text { e filho e à } \\
\text { amamentação na sala } \\
\text { de parto entre } \\
\text { nutrizes atendidas em } \\
\text { um banco de leite } \\
\text { humano. }\end{array}$ & $\begin{array}{l}\text { Este estudo sugere a } \\
\text { importância do pré-natal } \\
\text { como momento oportuno } \\
\text { para informar às gestantes } \\
\text { sobre ocontato pele a pele e } \\
\text { a amamentação na sala de } \\
\text { parto. Ressalta-se a } \\
\text { necessidade da adoção de } \\
\text { medidas que priorizem o } \\
\text { contato pele } \\
\text { a pele e a amamentação na } \\
\text { sala de parto. }\end{array}$ \\
\hline $\begin{array}{l}\text { ROCHA I. S. et. } \\
\text { al., } 2018 .\end{array}$ & $\begin{array}{l}\text { Influência da } \\
\text { Autoconfiança } \\
\text { Materna sobre o } \\
\text { Aleitamento } \\
\text { Materno } \\
\text { Exclusivo aos } \\
\text { Seis Meses de } \\
\text { Idade: uma } \\
\text { revisão } \\
\text { sistemática. }\end{array}$ & $\begin{array}{lc}\text { Buscar } & \text { evidências } \\
\text { científicas } & \text { sobre a } \\
\text { questão: } & \text { "Mãe } \\
\text { com } & \text { mais } \\
\text { confiança conse- } & \text { conentar } \\
\text { gue amament } & \\
\text { exclusivamente por } 6 \\
\text { meses?". }\end{array}$ & $\begin{array}{l}\text { A autoconfiança da mulher } \\
\text { está associada com maior } \\
\text { duração do AME. É } \\
\text { interessante salientar a } \\
\text { importância do profissional } \\
\text { da saúde em reconhecer a } \\
\text { autoeficácia materna. }\end{array}$ \\
\hline $\begin{array}{l}\text { RIMES; } \\
\text { OLIVEIRA; } \\
\text { BOCCOLINI, } \\
2019 . \\
\text { Revista } \\
\text { Saúde Pública. }\end{array}$ & $\begin{array}{l}\text { Licença- } \\
\text { Maternidade } \\
\text { Aleitamento } \\
\text { Materno } \\
\text { Exclusivo. }\end{array}$ & $\begin{array}{l}\text { Analisar a } \\
\text { associação entre a } \\
\text { licença- maternidade } \\
\text { e o } \\
\text { AME e estimar a } \\
\text { prevalência de } \\
\text { AME em crianças } \\
\text { menores de seis } \\
\text { meses de vida. }\end{array}$ & $\begin{array}{l}\text { A licença-maternidade } \\
\text { contribuiu para a prática do } \\
\text { AME em crianças menores } \\
\text { de seis meses, o que indica a } \\
\text { importância desse } \\
\text { benefício. Assim, ossetores } \\
\text { saúde e trabalho precisam } \\
\text { caminhar } \\
\text { juntos no que se refere à } \\
\text { proteção } \\
\text { amamentação. }\end{array}$ \\
\hline
\end{tabular}




\begin{tabular}{|c|c|c|c|}
\hline $\begin{array}{c}\text { Autores/ } \\
\text { Periódico/Ano }\end{array}$ & Título & Objetivo & Resultados \\
\hline $\begin{array}{l}\text { ALVES; } \\
\text { OLIVEIRA; } \\
\text { RITO, 2018. } \\
\text { Ciência \& Saúde } \\
\text { Coletiva. }\end{array}$ & \begin{tabular}{l} 
Orientações Sobre \\
Amamentação na \\
\multicolumn{1}{r}{ Atenção } \\
Básica \\
Saúde de \\
Associação como \\
\multicolumn{2}{c}{ Aleitamento } \\
Materno \\
Exclusivo.
\end{tabular} & $\begin{array}{lr}\text { Analisar a } & \text { as- } \\
\text { sociação entre } & \text { o } \\
\text { recebimento } & \text { de } \\
\text { orientações } & \text { sobre } \\
\text { amamentação } & \text { na } \\
\text { atenção básica } & \text { à } \\
\text { saúde e o AME. }\end{array}$ & $\begin{array}{l}\text { Ter recebido orientação } \\
\text { sobre o AME contribuiupara } \\
\text { o mesmo, enquanto } \\
\text { orientações e práticas } \\
\text { inadequadas } \\
\text { associaram a uma menor } \\
\text { prevalência do desfecho. } \\
\text { Recomenda-se que a rede } \\
\text { primária de saúde preste } \\
\text { orientações às gestantes e } \\
\text { mães sobre os benefícios e o } \\
\text { manejo do AM. Os } \\
\text { profissionaisde saúde devem } \\
\text { possuir habilidades } \\
\text { aconselhamento de } \\
\text { mães. às }\end{array}$ \\
\hline
\end{tabular}

Fonte: As autoras, 2020.

Com relação ao ano de publicação dos artigos selecionados, se destacou o ano de 2018, com 18 publicações (60\%); 2019 com 4 publicações (13,33\%); os anos

de 2016 e 2017 com 3 publicações cada (10\%), seguidos do anos de 2020 e 2015

com 1 publicação cada (3,33\%).

Analisando os periódicos selecionados nos quais as publicações foram veiculadas, pode-se verificar que a Revista de Enfermagem UFPE online se destacou com 4 artigos (13,33\%); seguida pela Ciência \& Saúde Coletiva com 3 (10\%); em seguida: Revista Paulista de Pediatria, Revista Rene, Revista Brasileira de Saúde Materno Infantil, Revista de Enfermagem da UERJ, Revista Gaúcha de Enfermagem, Texto e Contexto Enfermagem, ambas com 2 publicações cada (6,66\%) e por fim: Escola Anna Nery, Revista Online de Pesquisa, Caderno de Saúde Coletiva, Revista Nursing, Revista da Escola de Enfermagem da USP, Ciência, Cuidado e Saúde, Revista de Saúde Pública, Caderno de Saúde Pública, Revista de Nutrição, REME e Saúde e Pesquisa 1 das publicações cada (3,33\%).

Quanto ao conteúdo dos artigos, evidenciou-se que o conhecimento produzido congregou temas principais como fatores que influenciam na adesão e manutenção do aleitamento materno, os benefícios da prática e a importância da equipe de enfermagem e do enfermeiro em todo o ciclo gestacional e puerperal, promovendo a amamentação. 


\subsection{CONSIDERAÇÕES SOBRE A AMAMENTAÇÃO AO SEIO MATERNO}

Nas últimas décadas, houve aumento da prevalência global do AM, mas são poucas as regiões do mundo em que metade das crianças com idade inferior a seis meses recebem leite materno de forma exclusiva (SILVA, M.F.F.S. et al., 2018). O Brasil tem registrado avanços na prática da amamentação, porém a oferta precoce de outros alimentos à criança é uma preocupação (ROCHA G. P. et al., 2018). Amamentar é um ato milenar, não tem custo e é essencial para o ser humano (COSTA et al., 2018). Entretanto, amamentar não é um ato instintivo do ser humano. É um processo que deve ser aprendido para ter êxito, levando em consideração que as nutrizes necessitam de esforço e apoio constantes (SILVA L. L. A. et al., 2018).

O leite materno possui diversos fatores imunológicos que protegem a criança contra infecções (FREITAS; WERNECK; BORIM, 2018). Ele é composto por proteínas, gorduras e carboidratos, e é considerado um alimento imprescindível e essencial para o desenvolvimento do bebê (SILVA A. M. et al., 2018).

Para as mães, o AM promove a involução uterina no pós-parto, diminui a chance de desenvolvimento do câncer de mama, ovário e útero, minimiza gastos com compras de alimentos industrializados para a criança e com tratamentos de possíveis doenças. Para o bebê, promove o desenvolvimento correto da face, fonação, respiração e deglutição (ROCHA I. S. et al., 2018).

As vantagens da amamentação ao binômio e à sociedade são indiscutíveis. O leite materno é um alimento completo para bebês até seis meses de vida, atendendo às suas necessidades nutricionais. Porém sua interrupção ou a continuidade desta ação se relaciona com fatores biológicos, socioeconômicos e culturais (DOMINGUES et al., 2017). As mães sofrem muitas influências sobre sua decisão de amamentar, como a falta de conhecimento e motivação, e a facilidade do uso das fórmulas (ALMEIDA; LUZ; UED, 2015).

O período que abrange as duas primeiras semanas pós-parto, na residência, é julgado o mais difícil para o AM, e podem surgir problemas relacionados com a dificuldade inicial de amamentar, ou ao desconhecimento da prática que podem gerar complicações e levar ao desmame precoce (COSTA et al., 2018). Os principais motivos relatados pelas mães para o desmame são de ordem educacional/cultural, o que desvela a necessidade de acompanhamento e orientações (LIMA et al., 2019). 
Dentre os problemas mamários que dificultam e até mesmo interrompem a amamentação, pode-se citar o ingurgitamento mamário, a mastite, a fissura ou ferida mamilar, bem como a dor e formação de abscessos. O posicionamento correto do binômio durante a amamentação é um passo fundamental para que ocorra a pega adequada (BARBOSA et al., 2018).

É necessário um planejamento da alta que envolva a puérpera, sua família, a equipe multidisciplinar e uma rede de atenção à saúde, e que existam ações articuladas entre a unidade hospitalar e o serviço de referência básica para que seja garantido o cuidado integral (LIMA et al., 2019).

Uma das estratégias usadas para garantir maior adesão à prática da amamentação é garantir à mãe os conhecimentos e atitudes necessários para o desenvolvimento de sua autoeficácia em amamentar. Quando um indivíduo se sente autoeficaz adquire motivação, contribuindo na modificação do comportamento (SILVA, M. F. F. S. et al., 2018). A autoeficácia materna é considerada um preditor para a amamentação, e pode ser modificado através de intervenções educativas JAVORSKI et al., 2018).

Neste contexto, o apoio profissional pode favorecer o desenvolvimento da autoeficácia materna, através de ações em todos os momentos do ciclo gravídico puerperal, considerando que o sucesso em amamentar depende de uma atitude autoeficaz (SILVA, M.F.F.S. et al., 2018). Pois a confiança em amamentar ou sua falta é uma variável importante para iniciar e também mantê-la exclusivamente (JAVORSKI et al., 2018).

As políticas de saúde púbica em saúde da criança e mulher estabelecem ações de apoio articuladas com as redes de atenção básica e hospitalar, com estratégias importantes para o início e a manutenção do AM. Assim, o Programa Nacional de Incentivo ao Aleitamento Materno (PNIAM), criado em 1981 pelo MS, conjugou atuações multissetoriais, principalmente nas áreas de assistência à saúde, legislação e comunicação social (ALVES et al., 2016).

A Rede Amamenta Brasil, fundada em 2008, é uma estratégia criada com o objetivo de proporcionar o aumento dos índices de amamentação no país. Utiliza-se da circulação e troca de informações, e orienta que seja realizada a capacitação dos profissionais nas unidades básicas de saúde (UBS) para que sejam agentes de mudança, compreendendo a importância destes profissionais que se encontram em situação ímpar de atuação (DOMINGUES et al., 2017).

É recomendado que a rede primária preste orientações às gestantes e mães sobre os benefícios e o manejo do AM. Os profissionais precisam desenvolver habilidades de aconselhamento e capacitação 
em estratégias de promoção e apoio ao AM, para que suas orientações sejam efetivas e as mães possam se sentir seguras e superar as possíveis dificuldades (ALVES; OLIVEIRA; RITO, 2018).

A portaria 1459/11 instaurou o Programa Rede Cegonha com a meta de executar ações de assistência ao parto e nascimento, objetivando garantir acesso integral, acolhimento e resolutividades. Desta forma, as Boas Práticas de Atenção ao Parto e Nascimento, contidas no documento da OMS de 1996 e promovidas na Rede Cegonha, garantem os direitos da gestante e orienta os profissionais (CASTRO et al., 2019).

No Brasil, o alojamento conjunto (AC) é o modelo assistencial adotado para o atendimento do binômio. É um ambiente em que a interação deve ser incentivada. A permanência contínua promovida permite que os pais recebam orientações relacionadas aos cuidados com o filho, e ocorre o incentivo à amamentação, favorecimento do vínculo familiar e redução da incidência de infecção hospitalar. É um importante local para a continuidade do trabalho realizado no pré-natal (MERCADO et al., 2017).

A literatura sugere também que políticas favoráveis à licença-maternidade são efetivas em aumentar a prática do AME nos seis primeiros meses de vida do bebê. A licença maternidade contribui e revela a importância desse benefício na proteção do AME para as mulheres inseridas no mercado de trabalho formal (RIMES; OLIVEIRA; BOCCOLINI, 2019).

Coca et at. (2018) afirmam que é fundamental o estabelecimento de medidas de proteção ao AM que envolvam todos os profissionais de saúde para reduzir os índices do desmame precoce. Silva L. L. A. et al. (2018) complementam que as mães precisam perceber que os profissionais de saúde estão aptos para auxiliá-las, para que se sintam apoiadas e confiantes, sendo necessárias intervenções de promoção ao AM e prevenção do desmame.

Quando o incentivo à amamentação não é direcionado ao binômio em seu contexto social, político e econômico, as causas da interrupção ou mesmo da negação em amamentar estão circunscritas a alegações como leite fraco, pouco leite, leite secou ou mesmo ao desinteresse da mulher (DOMINGUES et al., 2017).

O desmame é definido pela introdução de qualquer alimento na dieta de uma criança que se encontrava em AME. O período de desmame é compreendido desde a introdução de novos alimentos até a eliminação completa do $\mathrm{AM}$, sendo considerado precoce quando ocorre antes de a criança completar seis meses de vida. O desmame precoce, em populações de baixas condições 
socioeconômicas, aumenta a morbimortalidade das crianças e compromete o desenvolvimento das mesmas. E configura um problema de saúde pública (MARTINS et al., 2018).

Mesmo que se inicie a amamentação após o parto, muitas mães abandonam ou complementam esse exercício nas primeiras semanas. Dentre os motivos, destacam-se: dificuldade de pega e sucção, mamilos planos ou invertidos e/ou doloridos e produção insuficiente de leite, fatores emocionais da mãe, a condição socioeconômica, o grau de escolaridade, o incentivo da família, a real intenção de amamentar, e também a falta de conhecimentos (ROCHA I. S. et al., 2018).

É preciso aliar o apoio emocional às informações práticas corretas de amamentação às mães que estejam com dificuldades em amamentar, possibilitando intervenções mais eficazes (DOMINGUES et al., 2017).

A capacitação dos profissionais de saúde se configura como um fator fundamental para a melhoria dos conhecimentos, habilidades e práticas profissionais e hospitalares, corroborando como que é indicado pelo passo 2 da IHAC, que é capacitar toda a equipe. A Política Nacional de Educação Permanente em Saúde (Portaria GM/MS 1996 de 20 de agosto de 2007) também apoia a necessidade de mudar as práticas institucionais por meio da formação e do desenvolvimento dos profissionais de saúde (JESUS; OLIVEIRA; MORAES, 2017).

Assim, as ações de incentivo, promoção e apoio ao AM devem ocorrer no conjunto das ações dos profissionais, durante o pré-natal, o pré-parto, o nascimento, e também nas imunizações, teste do pezinho e retorno na consulta puerperal. É fundamental que toda a equipe assuma o papel de acolhimento de mães e bebês, com disponibilidade para a escuta e o esclarecimento das dúvidas e aflições, incentivando as trocas de experiências (ALMEIDA; LUZ; UED, 2015).

\subsection{A IMPORTÂNCIA DA AMAMENTAÇÃO NA PRIMEIRA HORA DE VIDA DO RECÉM-NASCIDO}

O exercício de amamentar passou por inúmeras influências sociais e culturais em função das épocas e costumes de cada momento histórico, contudo, o estabelecimento concreto de seus benefícios foi verificado por meios científicos há mais de 50 anos (GASPARIN et al., 2020). Percebe-se que a amamentação na primeira hora configura um índice de excelência das práticas de AM, pois é um fator de proteção para a sobrevivência e desenvolvimento das crianças nos primeiros meses de vida (SILVA J. L. P. et al., 2018).

Entretanto são observadas baixas taxas de amamentação nas primeiras horas de vida, em todo o mundo. O início precoce da amamentação é visto com um fator essencial para a sua continuidade 
exclusiva e prolongada, não apenas pela oferta do colostro e seus benefícios nos primeiros dias que sucedem o parto, mas pela necessidade de adaptação da criança e da mãe ao processo (COCA et al., 2018).

Quando estabelecida de forma precoce, a amamentação proporciona inúmeros benefícios, o leite materno apresenta grande teor nutricional, auxilia na redução da morbimortalidade neonatal, desenvolve defesas imunológicas, auxilia no aperfeiçoamento sensorial e cognitivo do bebê, ocorre consolidação de vínculos e contribui para o prolongamento da amamentação exclusiva (CASTRO et al., 2019). Fassarela et al. (2018) pontuam, também, que a mamada precoce favorece a dequitadura da placenta.

Estudos tem observado a redução da mortalidade neonatal tardia, em decorrência de maior prevalência da amamentação na primeira hora de vida (AMPH) em hospitais amigo da criança (HAC), o que reforça a importância desta prática como um fator de proteção à sobrevivência infantil. É necessário preconizar o adiamento dos cuidados de rotina ao $\mathrm{RN}$, dando oportunidade ao contato pele a pele, favorecendo o início precoce do AM. A OMS recomenda que este procedimento seja incorporado aos padrões nacionais de cuidados de saúde materna, neonatal e infantil, visando à prevenção de mortes infantis (SILVA O. L. O. et al., 2018).

Segundo a OMS, é uma ação primacial, após o parto, o estímulo à amamentação logo após o nascimento, assim que possível, com o contato pele a pele imediato e ininterrupto. Pratica que é embasada na relação mãe-bebê nos primeiros minutos de vida, quando a criança estabelece o contato pele a pele, e é posicionada sobre a mãe, em estado de alerta para iniciar a sucção ao seio materno.

O contato pele a pele desenvolve sentimentos de amor, proteção, bem estar, aconchego e comodidade para o binômio (CASTRO et al., 2019).

Esta prática pode reduzir até $22 \%$ da mortalidade neonatal. O que pode estar relacionado à colonização intestinal do RN por bactérias saprófitas encontradas no leite materno e aos fatores imunológicos bioativos adequados para o RN, que são liberados no leite humano, de acordo com a idade gestacional (CRUZ et al., 2018).

O ato de amamentar imediatamente após o nascimento, com o contato pele a pele, poderá liberar e manter a liberação da ocitocina, contribuindo para evitar morbidades maternas relacionadas às hemorragias pós-parto. A presença da ocitocina em maior quantidade permite que o útero se contraia mais rapidamente (NETTO et al., 2016). Silva J. L. P. et al. (2018) explicam que a amamentação estimula 
a hipófise materna na produção de ocitocina e prolactina, o que favorece a produção de leite pelo organismo.

O contato pele a pele (CPP) e a amamentação na primeira hora de vida têm sido difundidos como prática de humanização do atendimento à mulher no parto, promovendo a qualidade da assistência na sala de parto. A prática do CPP é definida como o contato direto (despido) e imediato do RN com sua mãe, dentro dos primeiros cinco minutos de vida, e continuado por pelo menos uma hora sem que haja a separação da dupla (SACO et al., 2019).

O CPP precoce, com a colocação do bebê nu, em posição de prona, sobre o peito da mãe tem o intuito de favorecer a adaptação na transição dos espaço intra para o extrauterino, incentivando a amamentação imediatamente após o parto. Estratégia que visa a promoção, proteção e apoio ao AM e se baseia na capacidade de interação dos RN com suas mães após o nascimento (SILVA et al., 2016). Sentir o cheiro da mãe e do leite materno, através do CPP, contribui para que o bebê descubra o seio materno, favorecendo o início do aleitamento. Assim como, as batidas do coração materno e som da voz da mãe acalentam e possibilitam estabilidade emocional ao RN (CASTRO et al., 2019).

A amamentação pode ainda promover ganhos psicológicos ao binômio. Uma amamentação prazerosa, os olhos nos olhos e o contato continuado entre a mãe e o filho fortalecem os laços afetivos entre eles, permitindo a intimidade, a troca de afeto e sentimentos de segurança e proteção na criança e de autoconfiança e realização na mulher. Amamentar é uma maneira especial de comunicação entre a mãe e seu filho, uma oportunidade de a criança aprender desde cedo a se comunicar com confiança e afeto (BRASIL, 2015).

O contato com a mãe imediatamente após o nascimento também tem sido orientado pela UNICEF, reforçado pelos benefícios em curto, médio e longo prazo que tal prática pode oferecer. Imediatamente após o nascimento, o RN passa por um período de inatividade alerta, que pode durar aproximadamente 40 minutos. Neste tempo, o contato da criança direto com a pele da mãe, além de desenvolver o vínculo, propicia níveis favoráveis de batimentos cardíacos e respiração da criança, além de favorecer a amamentação precoce e a diminuição do choro (COCA et al., 2018).

Saco et al. (2019) complementam alguns benefícios do contato pele a pele: melhor controle glicêmico do neonato, o controle da temperatura corporal, a estabilização da dinâmica cardiovascular, menor perda de peso corporal e satisfação materna. E as boas condições de nascimento do bebê são fatores protetores para a realização desta ação. 
Apesar de reconhecida a importância de tal ação, alguns hábitos e rotinas hospitalares dificultam sua efetividade, como os cuidados imediatos ao RN; maior incidência de cesarianas; consequente redução do estado de alerta do bebê; e acentuada analgesia do parto, que pode acarretar sonolência materna. Também são observadas dificuldades relacionadas à resistência dos profissionais, desconhecimento das vantagens da prática e até mesmo a política da instituição (SILVA et al., 2016).

Colocar o RN para mamar na primeira hora de vida, imediatamente após o parto, encoraja e incentiva as mães na compreensão da importância de amamentar. Quando se prorroga essa mamada inicial crescem as chances de mortalidade neonatal decorrente de uma diversidade de infecções. É importante favorecer a amamentação logo após o nascimento, no momento em que a mãe e o RN estão alerta (NETTO et al., 2016).

A existência desta ação se relaciona com a garantia de condutas menos intervencionistas baseadas em práticas benéficas ao acompanhamento do parto e nascimento, que permitam esse contato imediato e suporte da amamentação (CASTRO et al., 2019).

Na sala de parto, todos os profissionais atuantes são responsáveis pela amamentação precoce, dentre eles, o profissional de enfermagem. Cabe a ele o papel de facilitador da mamada precoce, especialmente ao fornecer informações e auxiliar no manejo da lactação na sala de parto. 0 Enfermeiro atuará estimulando os demais profissionais de saúde, sensibilizando-os, informando e integrando estes ao programa de incentivo, promoção e apoio à amamentação na primeira hora de vida do RN (SILVA J. L. P. et al., 2018).

Mesmo que o processo de amamentar esteja direcionado à mulher, tido como um ato natural, ele é, na verdade, o resultado de fatores comportamentais e pode ser trabalhado e assimilado, principalmente em mães de primeira viagem. É preciso estimular, orientar e oferecer suporte para que as puérperas iniciem de forma precoce o AM e que este perdure exclusivamente até os seis meses de vida do bebê (CASTRO et al., 2019).

A colocação do RN para mamar na primeira hora permanece como um desafio para os serviços hospitalares, mesmo que sejam conhecidos os benefícios da prática. Faz-se necessária a atuação dos enfermeiros conjuntamente às equipes de saúde, embasados nos conhecimentos científicos, habilidades de comunicação e competência técnica, para assim informar e sensibilizar as famílias, comunidades e demais profissionais sobre a importância da amamentação (NETTO et al., 2016). 


\subsection{CONTRIBUIÇÕES DO ENFERMEIRO NA AMAMENTAÇÃO NA PRIMEIRA HORA DE VIDA DO RN}

Os índices e a duração do AME podem ser influenciados por intervenções de orientação e apoio ao AM realizados pelos profissionais de saúde (ALVES; OLIVEIRA; RITO, 2018). O enfermeiro, como membro que atua na assistência direta à saúde materna e infantil, em todos os níveis de atenção, apresenta um papel singular na promoção, proteção e incentivo ao AM, através de orientações durante o pré-natal e puerpério, com a finalidade de estimular esta prática. É necessário ainda, para o sucesso da amamentação, o envolvimento das redes de apoio formais e informais, familiares e demais profissionais de saúde (ALVES et al., 2018).

Os profissionais de saúde devem promover o AM e estar capacitados para fornecer informações e ter habilidade prática no manejo da amamentação. A comunicação é indispensável para que as dificuldades sejam identificadas, favorecendo a criação de vínculo com as nutrizes e o estabelecimento de um plano de cuidado (FREITAS; WERNECK; BORIM, 2018).

O período imediato após o parto é o momento de maior sensibilidade da puérpera, e o incentivo à amamentação na primeira hora é essencial para estabelecer a afetividade e encorajar a mãe no cuidado com o seu bebê. Medida que deve ser estimulada pelo profissional a fim de proporcionar a experiência de amamentar à mulher, e promover a construção dos laços afetivos. Cabe à equipe proporcionar o apoio às mães durante a primeira mamada e nas seguintes, se necessário, garantindo a segurança de que o RN conseguirá uma sucção efetiva (NETTO et al., 2016).

O puerpério é considerado um momento crítico e de modificações biológicas e psicológicas, bem como de inserção social, quando a mulher vivencia as primeiras demandas da maternidade, amamentação, banho e cuidados com o seu RN e a necessidade do seu próprio autocuidado. A mulher pode sentir-se emocionalmente vulnerável perante a insegurança, ansiedade e dúvidas. São momentos em que o enfermeiro deve direcionar um cuidado que atenda às necessidades do binômio (MERCADO et al., 2017).

Apenas as informações são insuficientes para que as mulheres possam ser motivadas e tenham sucesso na amamentação. Pois possuir informação não significa necessariamente ter conhecimento, ter o conhecimento não significa que ocorrerá a mudança, e a decisão do AM perpassa pelo ato de realizar a amamentação. Assim, a atuação do enfermeiro precisa ser valorizada, para que ele possa colocar em prática a promoção, proteção e apoio ao AM. Apoio que sugere um suporte emocional por parte do profissional, contribuindo com a mulher para a superação de seus obstáculos no ato de 
amamentar, além de fornecer apoio com as ambiguidades dos sentimentos que ela manifesta e que envolvem o aleitamento e que podem ser prejudiciais à pratica (COSTA et al., 2018).

Quando realizado por profissional qualificado, o manejo clínico da amamentação visa o estímulo do AM através de demonstrações de práticas corretas às mulheres, observando e corrigindo alguns problemas comuns, como o erro de pega e sucção, trabalhando a insegurança materna e também prevenindo agravos como infecções mamilares e mastites (COSTA et al., 2018).

O desempenho da amamentação é uma habilidade que precisa ser apreendida pela observação e pela prática, ponderando que existem evidências de que a amamentação proporciona benefícios para as crianças e suas mães. Assim, aatuação profissional é essencial no puerpério, o que exige um comprometimento diferenciado no cuidado à mãe, à criança e sua família (MARTINS et al., 2018).

A promoção e o apoio ao AM realizados pelos profissionais enfermeiros configura uma estratégia de orientação com foco educativo, favorecendo o conhecimento da posição adequada da criança junto ao seio materno, inibindo os riscos das complicações mamárias. O profissional deve ser um facilitador da prática da amamentação valendo-se de informações adequadas ao entendimento e conhecimento da nutriz. É necessário demonstrar à mulher, na prática profissional, como é realizado o manejo da amamentação (COSTA et al., 2018).

O enfermeiro precisa de conhecimentos técnico e científico para intervir nas intercorrências e aconselhar a nutriz sobre os detalhes da prática do AM, posição e pega adequadas, além de atuar nos cuidados com as mamas, tempo das mamadas, utilizando uma comunicação simples e objetiva (MERCADO et al., 2017).

Faz-se necessário aliar apoio emocional às informações sobre as práticas corretas de amamentação às mães, o que configura em mais eficazes intervenções de encorajamento (DOMINGUEZ et al., 2017). A enfermagem dispõe de diversas estratégias para promover o aleitamento precoce, sejam elas elencadas na educação em saúde, ou no vínculo facultado pelo acolhimento. A presença do conhecimento científico se torna fator crucial para que as condições supracitadas sejam alcançadas (FASSARELA et al., 2018).

De acordo com a OMS, existem pontos chaves a serem observados que garantem o posicionamento e pega adequados na amamentação. O corpo do bebê precisa estar próximo ao da mãe e bem apoiado, o bebê deve manter cabeça e tronco alinhados, o rosto do bebê deve estar posicionado de frente para a mama, com o nariz na altura do mamilo. Uma pega adequada é alcançada quando há mais aréola 
visível acima da boca do RN, o bebê deve ter a boca bem aberta com o lábio inferior virado para fora e o queixo tocando a mama (BRASIL, 2015).

Os enfermeiros precisam estar preparados para atuar perante as dificuldades apresentadas na amamentação, sejam da nutriz ou da criança. Ao promover estratégias buscando a diminuição das taxas de desmame precoce, deve reconhecer os motivos que contribuem com esta prática, visando a prevenção, o apoio e a assistência resolutiva que favorecem o sucesso do AM. São necessárias intervenções educativas na promoção à amamentação, em todos os níveis de atendimento, do prénatal ao pós-parto tardio, considerando as características socioculturais e clínicas da população assistida, através de um atendimento qualificado e humanizado, favorecendo a adaptação ao AM, esclarecendo dúvidas, dificuldades e evitando possíveis complicações (MARTINS et al., 2018).

A enfermagem obstétrica e neonatal recomenda uma assistência centrada na humanização como ferramenta de cuidado à parturiente. A Portaria 985/GM, de 05 de agosto de 1999, assegura o acesso à assistência de parto nos serviços do Sistema Único de Saúde (SUS) e também ações que visam a diminuição da morbimortalidade materno-infantil, humanização e a melhoria da qualidade da assistência. Desta maneira, foram criados os Centros de Parto Normal (CPN) para atendimentos à mulher no ciclo gravídico, com a oferta de serviços humanizados e de qualidade, no cuidado ao parto normal (CASTRO et al., 2019).

No contexto hospitalar, no AC, o enfermeiro deve juntamente com a equipe e demais profissionais, exercer ações referentes ao cuidado ao binômio, sendo o responsável pela educação em saúde no que se refere ao incentivo à amamentação, aos cuidados com o RN, esclarecendo as dúvidas e oferecendo apoio às puérperas e orientando quanto aos acompanhamentos de consultas da criança, vacinação e planejamento familiar. Ações que exigem do profissional enfermeiro habilidades de comunicação, acolhimento, avaliação, monitoramento e disponibilidade, que são itens que requerem tempo e competência profissional para que as puérperas sintam- se acolhidas pelas práticas de enfermagem no atendimento às suas necessidades (MERCADO et al., 2017).

É confiada ao enfermeiro a capacidade de melhorar e transformar as práticas vigentes na sala de parto, iniciando por sua presença e postura no nascimento; seguindo com a educação continuada junto à equipe, o que se traduz como indispensável para a responsabilidade e compromisso no cuidado materno-infantil humanizado e para o fortalecimento do AM na primeira hora de vida do RN (NETTO et al., 2016). A atuação do enfermeiro deve ser valorizada a fim de que ele possa implantar a promoção, a proteção e o apoio ao AM (COSTA et al., 2018). 
O enfermeiro é considerado o profissional que assegura a concretização do quarto passo da IHAC, pois exerce papel essencial no preparo das puérperas, ajudando-as a dar o peito e a driblar as adversidades que esta prática apresenta. A assistência de enfermagem, neste primeiro contato junto à amamentação, é oportuna, pois o profissional atua como um facilitador, desmistificando crenças, mitos e tabus que cercam o ato de aleitar. O compromisso da enfermagem é um fator determinante para a consolidação do direito de amamentar na primeira hora de vida do RN. A enfermagem é responsável pelo cuidado humanizando, reduzindo desconfortos e tornando a hora da amamentação agradável para o binômio (SILVA J. L. P. et al., 2018).

O Conselho Federal de Enfermagem (COFEN), por meio da resolução no. 358/2009 regulamenta a sistematização da Assistência de Enfermagem (SAE) e a implementação do Processo de Enfermagem (PE), em ambientes sejam públicos ou privados, onde ocorra o cuidado da enfermagem. A SAE organiza o trabalho profissional quanto à metodologia, pessoal e instrumentos, tornando possível a operacionalização do PE que orienta o cuidado prestado pelo profissional, contribuindo para o reconhecimento da assistência dispensada à população. O PE compreende as seguintes etapas: a coleta de dados de enfermagem ou histórico de enfermagem, o diagnóstico de enfermagem (DE), planejamento de enfermagem, a implementação e a avaliação de enfermagem (COFEN, 2009).

A SAE alicerçada no PE é uma ferramenta que pode ressignificar o cuidado, contribuindo para a evolução científica, promovendo o reconhecimento da profissão e sua autonomia, oferecendo subsídios para o planejamento da assistência, possibilitando a continuidade ao serviço prestado. Aproxima o enfermeiro do paciente, permitindo o cuidado individualizado, indicando as necessidades do paciente, documentando a assistência prestada, aumentando a autoestima profissional e dando visibilidade às falhas e resultados (CIPE, 2020).

Alguns dos diagnósticos de enfermagem, estabelecidos a partir da Taxonomia North American Nursing Diagnosis Assossiation - Internacional (NANDA), versão 2018-2020, que podem ser encontrados na assistência de enfermagem à amamentação, são: ansiedade, medo, dor aguda, amamentação eficaz, amamentação ineficaz, conhecimento deficiente, risco da integridade da pele prejudicada, processos familiares interrompidos e processos familiares melhorados, entre outros (Taxonomia North American Nursing Diagnosis Assossiation - Internacional, 2018). 


\section{CONSIDERAÇÕES FINAIS}

Com base no desenvolvimento deste estudo, constatou-se que o enfermeiro é um facilitador da mamada precoce. Sua atuação ética e comprometida com o bem estar da puérpera e do seu filho, na sala de parto, no atendimento pós-parto imediato, contribui para a efetivação da amamentação ao seio materno na primeira hora de vida do recém-nascido. $O$ enfermeiro concretiza a ação e também sensibiliza toda a equipe envolvida no parto sobre a importância desta prática, tanto para a mãe quanto para o bebê. Desta forma, o objetivo do trabalho foi alcançado e obtivemos resposta para a questão norteadora, quando evidenciamos, na pesquisa, as contribuições do enfermeiro na primeira hora de vida, contribuindo para a amamentação na primeira hora de vida do RN.

Compreendemos que a atuação do enfermeiro ocupa um lugar privilegiado junto à mulher, desde a gestação, nas consultas de pré-natal, perpassando todos os atendimentos individuais ou em grupos, oferecendo orientações e esclarecendo dúvidas, medos e mitos; até o acompanhamento no trabalho de parto, parto e puerpério. Seu lugar Ihe coloca em posição priorizada, mas também com uma grande responsabilidade, a de propiciar a efetivação da mamada precoce. É o dever do enfermeiro atuar junto à equipe, e também nas famílias assistidas, possibilitando que a gestante ou puérpera, sua família e toda a equipe de saúde valorize, compreenda, favoreça e concretize a amamentação na primeira hora de vida da criança. Os conhecimentos científicos inerentes à profissão e sua prática humanizada são diferenciais para que este objetivo seja alcançado.

Não foram encontradas dificuldades na busca e seleção dos artigos para realização da revisão de literatura, pois existem muitas publicações recentes envolvendo a temática da amamentação e sua relevância, bem como os benefícios para o binômio. Entretanto não foi encontrado, na literatura utilizada, um protocolo que oriente a atuação do enfermeiro na sala de parto com foco na concretização da amamentação precoce. Tal limitação abre possibilidades para novos estudos que possam abordar a construção de um regulamento que norteie o enfermeiro nessa efetivação da mamada precoce. O que desvela o interesse de novas pesquisas, por parte das futuras enfermeiras, enquanto pesquisadoras em saúde, na busca da valorização da prática da enfermagem através da construção de saberes pertinentes à atuação profissional. 


\section{REFERÊNCIAS}

ALMEIDA, Jordana Moreira de; LUZ, Sylvana de Araújo Barros; UED, Fábio da Veiga. Apoio ao Aleitamento Materno pelos Profissionais de Saúde: revisão integrativa da literatura. Revista Paulista de Pediatria, São Paulo, v. 33, n. 3, p. 355-362, set. 2015. Disponível em:

https://www.scielo.br/pdf/rpp/v33n3/0103-0582-rpp-33-03-0355.pdf. Acesso em: 01 out. 2020.

ALVES, Jéssica de Souza; OLIVEIRA, Maria Inês Couto de; RITO, Rosane Valéria Viana Fonseca. Orientações Sobre Amamentação na Atenção Básica de Saúde e Associação com o Aleitamento Materno Exclusivo. Ciência \& Saúde Coletiva, Rio de Janeiro, v. 23, n. 4, p. 1077-1088, abr. 2018. Disponível em: https://www.scielo.br/pdf/csc/v23n4/1413-8123-csc-23-04-1077.pdf. Acesso em: 01 out. 2020.

ALVES, Tássia Regine de Morais et al. Contribuições de Enfermeiros na Promoção do Aleitamento Materno Exclusivo. Revista Rene, Fortaleza, v. 19: e33072, p. 1-8, jan./dez. 2018. Disponível em: http://periodicos.ufc.br/rene/article/view/33072/pdf_1. Acesso em: 01 out. 2020.

ALVES, Valdecyr Herdy et al. Manejo Clínico da Amamentação: Valorização Axiológica sob a Ótica da Mulher-Nutriz. Escola Anna Nery [online], v. 20, n. 4, out./dez. 2016. Disponível em: https://www.scielo.br/pdf/ean/v20n4/1414-8145-ean- 20-04-20160100.pdf. Acesso em: 19 set. 2020.

BARBOSA, Gessandro Elpídio Fernandes et al. Dificuldades Iniciais com a Técnica da Mamada e Impacto na Duração do Aleitamento Materno Exclusivo. Revista Brasileira de Saúde Materno Infantil, Recife, v. 18, n. 3, p. 527-537, jul./set. 2018. Disponível em:

https://www.scielo.br/pdf/rbsmi/v18n3/pt_1519-3829-rbsmi-18-03- 0517.pdf. Acesso em: 01 out. 2020.

BRASIL. Ministério da Saúde (MS). Secretaria de Atenção à Saude. Departamento de Atenção Básica. Saúde da Criança: Aleitamento Materno e Alimentação Complementar. 2aa ed. Brasília, 2015. Disponível em:

https://bvsms.saude.gov.br/bvs/publicacoes/saude_crianca_aleitamento_materno_ca_b23.pdf. Acesso em: 19 set. 2020.

BRASIL. Ministério da Saúde (MS). Secretaria de Atenção à Saúde. Área Técnica de Saúde da Criança e Aleitamento Materno. Departamento de Ações Programáticas Estratégicas. Iniciativa Hospital Amigo da Criança. 1a ed. Brasília, 2011.

Disponível em: https://bvsms.saude.gov.br/bvs/publicacoes/rede_amamenta_brasil_primeiros _passos.pdf. Acesso em: 19 set. 2020.

CASTRO, Idalina Reis de et al. Partejar de Primíparas: reflexos na amamentação.

Revista de Enfermagem da UERJ, Rio de Janeiro, v. 27:e43354, p. 1-7, 2019. Disponível em: https://www.e-publicacoes.uerj.br/index.php/enfermagemuerj/article/ view/43354/32726. Acesso em: 01 out. 2020. 
Classificação Internacional para a Prática de Enfermagem (CIPE). O que é a SAE? Santa Rosa, 2020. Disponível em: http://cipeonline.com.br/site/. Acesso em: 31 out. 2020.

COCA, Kelly Pereira et al. Conjunto de Medidas para o Incentivo do Aleitamento Materno Exclusivo Intra-hospitalar: evidências de revisões sistemáticas. Revista Paulista de Pediatria, São Paulo, v. 36, n. 2, p. 214-220, jun. 2018. Disponível em: https://www.scielo.br/pdf/rpp/v36n2/0103-0582-rpp-201836-2-00002.pdf. Acesso em 01 out. 2020.

COSTA, Evelyn Farias Gomes da et al. Atuação do Enfermeiro no Manejo Clínico da Amamentação: Estratégias para o Aleitamento Materno. Revista Online de Pesquisa (Universidade Federal do Estado do Rio de Janeiro, Online), Rio de Janeiro, v. 10, n. 1, p. 217-223, jan./mar. 2018. Disponível em: http://www.seer.unirio.br/index.php/cuidadofundamental/article/view/5953/pdf.Acesso em: 19 set. 2020.

CONSELHO FEDERAL DE ENFERMAGEN (COFEN). 53\% das crianças são amamentadas no primeiro ano de vida no Brasil. Brasília, 2020. Disponível em: http://www.cofen.gov.br/53-das-criancas-saoamamentadas-no-primeiro-ano-de-vida-no-brasil-diz pesquisa_81510.html\#: :text=Dados\%20preliminares\%20de\%20 pesquisa\%20do,meses\%20recebem\%20leite\%20materno\%20exclusivo. Disponível em: 25 set. 2020.

CONSELHO FEDERAL DE ENFERMAGEM (COFEN). Cresce o número de Hospitais Amigos das Crianças. Brasília, 2010. Disponível em: http://www.cofen.gov.br/cresce-o-numero-de-hospitais-amigos-dascrianas_5300.html. Acesso em: 25 set. 2020.

CONSELHO FEDERAL DE ENFERMAGEN (COFEN). Lançamento da Campanha de Amamentação reúne nomes da saúde. Brasília, 2019. Disponível em: http://www.cofen.gov.br/lancamento-da-campanhade-amamentacao-reune-nomes-

dasaude_72757.html\#: :text=Lan\%C3\%A7amento\%20da\%20campanha\%20de\%20amamenta\%C3\%A7 \%C3\%A3o\%20re\%C3\%BAne\%20nomes\%20da\%20Sa\%C3\%BAde,A\%20Semana\%20Mundial\&text=Rea lizada\%20em\%20mais\%20de\%20170\%20pa\%C3\%ADses\%2C\%20a\%20Semana\%20Mundial\%20de,\%2 F7)\%2C\%20em\%2 OBras\%C3\%ADlia. Acesso em: 25 set. 2020.

CONSELHO FEDERAL DE ENFERMAGEN (COFEN). Resolução no 358/2009.

Dispõe sobre a Sistematização da Assistência de Enfermagem e a implementação do Processo de Enfermagem em ambientes, públicos ou privados, em que ocorre o cuidado profissional de Enfermagem, e dá outras providências. Brasília, 15 de out. de 2009. Disponível em: http:// www.cofen.gov.br/resoluo-cofen-3582009_4384.html+\&cd=1\&hl=pt-BR\&ct=clnk\&gl=br. Acesso em: 30 out. 2020.

CRUZ, Neusa Aparecida Casetto Vieira da et al. Associação entre o Tipo de Aleitamento na Alta Hospitalar do Recém-nascido e aos Seis Meses de Vida. Caderno de Saúde Coletiva, Rio de Janeiro, v. 26, n. 2, p. 117-124, 2018.

Disponível em: https://www.scielo.br/pdf/cadsc/v26n2/1414-462X-cadsc-26-2- 117.pdf. Acesso em: 01 out. 2020. 
DOMINGUEZ, Carmen Carballo et al. Dificuldades do Estabelecimento da Amamentação: Visão das Enfermeiras Atuantes nas Unidades Básicas de Saúde. Revista Enfermagem UERJ, Rio de Janeiro, v. 25:e14448, p. 1-6, 2017. Disponível em:

https://www.e-publicacoes.uerj.br/index.php/enfermagemuerj/article/view/14448. Acesso em: 19 set. 2020.

FASSARELLA, Bruna Porath Azevedo et al. Percepção da Equipe de Enfermagem Frente ao Aleitamento Materno: do Conhecimento à implementação. Revista Nursing, São Paulo, v. 21, n. 247, p. 2489-2493, dez. 2018. Disponível em:

http://www.revistanursing.com.br/revistas/247/pg43.pdf. Acesso em: 19 set. 2020.

FREITAS, Marina Guedes de; WERNECK, Alexandre Lins; BORIM, Bruna Cury. Aleitamento Materno Exclusivo: Adesão e Dificuldades. Revista de Enfermagem UFPE online, Recife, v. 12, n. 9, p. 2301-2307, set. 2018. Disponível em:

https://periodicos.ufpe.br/revistas/revistaenfermagem/article/view/234910/29901. Acesso em: 19 set. 2020.

GASPARIN, Vanessa Aparecida et al. Fatores Associados à Manutenção do Aleitamento Materno Exclusivo no Pós-parto Tardio. Revista Gaúcha de Enfermagem, Porto Alegre, v. 41 (esp):e20190060, p. 1-8, 2020. Disponível em: https://www.scielo.br/pdf/rgenf/v41nspe/pt_1983-1447-rgenf-41e20190060.pdf. Acesso em: 01 out. 2020.

JAVORSKI, Marly et al. Efeitos de uma Tecnologia Educativa na Autoeficácia para Amamentar e na prática do Aleitamento Materno Exclusivo. Revista da Escola de Enfermagem da USP, São Paulo, v. 52, e03329, p. 1-8, 2018. Disponível em: https://www.scielo.br/pdf/reeusp/v52/1980-220X-reeusp-52e03329.pdf. Acesso em: 01 out. 2020.

JESUS, Patrícia Carvalho de; OLIVEIRA, Maria Inês de; MORAES, José Rodrigo de. Capacitação de Profissionais de saúde em Aleitamento Materno e sua Associação com Conhecimento, Habilidades e Práticas. Ciência \& Saúde Coletiva, Rio de Janeiro, v. 22, n. 1, p. 311-320, jan. 2017. Disponível em: https://www.scielo.br/pdf/csc/v22n1/1413-8123-csc-22-01-0311.pdf. Acesso em: 01 out. 2020.

LIMA, Ana Paula Esmeraldo et al. Aleitamento Materno Exclusivo de Prematuros e Motivos para sua Interrupção no Primeiro Mês Pós-alta Hospitalar. Revista Gaúcha de Enfermagem, Porto Alegre, v. 40, e20180406, p. 1-8, out. 2019. Disponível em: https://www.scielo.br/pdf/rgenf/v40/1983-1447-rgenf40-e20180406.pdf. Acesso em: 01 out. 2020.

MARTINS, Daniela Pereira et al. Conhecimento de Nutrizes Sobre Aleitamento Materno: Contribuições da Enfermagem. Revista de Enfermagem UFPE online, Recife, v. 12, n. 7, p. 1870-1878, jul. 2018. Disponível em: https://periodicos.ufpe.br/revistas/revistaenfermagem/article/view/231338/29452. Acesso em: 19 set. 2020.

MARTINS, Maria de Fátima Moreira. Estudos de Revisão de Literatura. Rio de Janeiro, 17 de setembro de 2018. Disponível em: https://www.arca.fiocruz.br/bitstream/icict/29213/2/Estudos_revisao.pdf. Acesso em: 29 out. 2020. 
MERCADO, Nayara Caselato et al. Cuidados e Orientações de Enfermagem às Puérperas no Alojamento Conjunto. Revista de Enfermagem UFPE online, Recife, v. 11 (supl. 9), p. 3508-3515, set. 2017. Disponível em: https://periodicos.ufpe.br/revistas/revistaenfermagem/article/view/234480/27670.

Acesso em: 19 set. 2020.

NORTH AMERICAN NURSING DIAGNOSIS ASSOCIATION - NANDA International.

Diagnósticos de enfermagem da NANDA: definições e classificação 2018 - 2020. Porto Alegre: Artmed; 2018. Disponível em:

https://edisciplinas.usp.br/pluginfile.php/5015948/mod_resource/content/3/Ref\%2012.pdf. Acesso em: 31 out. 2020

NETTO, Amanda et al. Amamentação na Primeira Hora de Vida em Uma Instituição com Iniciativa Hospital Amigo da Criança. Ciência, Cuidado \& Saúde, Maringá,v. 15, n. 3, p. 515-521, jul./set. 2016. Disponível em:

http://www.revenf.bvs.br/scielo.php?script=sci_arttext\&pid=S1677- 38612016000300515. Acesso em: 19 set. 2020.

ORGANIZAÇÃO PAN-AMERICANA DA SAÚDE/ORGANIZAÇÃO MUNDIAL DA SAÚDE (OPAS/OMS). BRASIL. Semana Mundial de Aleitamento Materno, Brasília, jul. 2019. Disponível em: https://www.paho.org/bra/index.php?option=com_content\&view=article\&id=5997:semanamundial-de-aleitamento-materno-sucesso-da-amamentacao-nao-e- responsabilidade-exclusiva-damae-mas-de-todos-nos-afirma-representante-da-opas-oms-no brasil\&Itemid=839\#: :text=Panorama\%20mundial\&text=Estima\%2Dse\%20que\%2C

\%20em\%202017,analisa\%20dados\%20de\%2076\%20pa\%C3\%ADses. Acesso em: 19 set. 2020.

REDE BRASILEIRA DE BANCOS DE LEITE HUMANO. Fundação Oswaldo Cruz.

Comunicação e Informação: Aleitamento Materno, 2020. Disponível em:

http://www.redeblh.fiocruz.br/cgi/cgilua.exe/sys/start.htm?sid=384. Acesso em: 19 set. 2020.

RIMES, Karina Abibi; OLIVEIRA, Maria Inês Couto de; BOCCOLINI, Cristiano Siqueira. Licençamaternidade e Aleitamento Materno Exclusivo. Revista de Saúde Pública, São Paulo, v. 53, n. 10, p. 112, 2019. Disponível em: https://www.scielo.br/pdf/rsp/v53/pt_1518-8787-rsp-53-10.pdf. Acesso em: 01 out. 2020 .

ROCHA, Gabriele Pereira et al. Condicionantes da Amamentação Exclusiva na Perspectiva Materna. Cadernos de Saúde Pública, v. 34, n. 6, p. 1-13, set. 2018. Disponível em: https://www.scielo.br/pdf/csp/v34n6/1678-4464-csp-34-06- e00045217.pdf. Acesso em: 01 out. 2020.

ROCHA, Isabela Silva et al. Influência da Autoconfiança Materna sobre o Aleitamento Materno Exclusivo aos Seis Meses de Idade: uma revisão sistemática. Ciência \& Saúde Coletiva, Rio De Janeiro, v. 23, n. 11, p. 3609-3619, nov. 2018. Disponível em: https://www.scielo.br/pdf/csc/v23n11/14138123-csc-23-11-3609.pdf. Acesso em: 01 out. 2020. 
SACO, Márcia Carneiro et al. Contato Pele a Pele e Mamada Precoce: fatores associados e influência no aleitamento materno exclusivo. Texto e Contexto Enfermagem, Florianópolis, v. 28, e20180260, p. 1-12, dez. 2019. Disponível em: https://www.scielo.br/pdf/tce/v28/pt_1980-265X-tce-28e20180260.pdf. Acesso em: 01 out. 2020.

SILVA, Amanda Marinho da et al. Aleitamento Materno Exclusivo: Empecilhos Apresentados por Primíparas. Revista de Enfermagem UFPE online, Recife, v. 12, n. 12, p. 3205-3211, dez. 2018. Disponível em: https://periodicos.ufpe.br/revistas/revistaenfermagem/article/view/236599/30770.

Acesso em: 19 set. 2020.

SILVA, Cristianny Miranda et al. Fatores Associados ao Contato Pele a Pele entre Mãe/filho e Amamentação na Sala de Parto. Revista de Nutrição, Campinas, v. 29,

n. 4, p. 457-471, jul./ago. 2016. Disponível em: https://www.scielo.br/pdf/rn/v29n4/1415-5273-rn29-04-00457.pdf. Acesso em: 01 out. 2020.

SILVA, Daniele Duarte da et al. Promoção do Aleitamento Materno no Pré-Natal: Discurso das Gestantes e dos Profissionais de Saúde. REME - Revista Mineira de Enfermagem, Belo Horizonte, v. 22:e-1103, p. 1-9, 2018. Disponível em: https://cdn.publisher.gn1.link/reme.org.br/pdf/e1103.pdf. Acesso em: 19 set. 2020.

SILVA, Juliane Lima Pereira da et al. Fatores Associados ao Aleitamento Materno na Primeira Hora de Vida em um Hospital Amigo da Criança. Texto Contexto - Enfermagem, Florianópolis, v. 27, n.4, p. 110, jan. 2018. Disponível em: https://www.scielo.br/pdf/tce/v27n4/0104-0707-tce-27-04e4190017.pdf. Acesso em: 19 set. 2020.

SILVA, Leylla Lays Alves et al. Prevalência do Aleitamento Materno Exclusivo e Fatores de Risco. Saúde e Pesquisa, Maringá, v. 11, n. 3, p. 527-534, set./dez. 2018. Disponível em:

http://periodicos.unicesumar.edu.br/index.php/saudpesq/article/ view/6871. Acesso em: 01 out. 2020

SILVA, Maria de Fátima Fernandes Santos et al. Autoeficácia em Amamentação e Fatores Interligados. Revista Rene, Fortaleza, v.19:e3175, p. 1-7, 2018. Disponível em:

http://periodicos.ufc.br/rene/article/view/31315/pdf. Acesso em: 19 set. 2020.

SILVA, Osvaldinete Lopes de Oliveira et al. A Iniciativa Hospital Amigo da Criança: contribuição para o incremento da amamentação e a redução da mortalidade infantil no Brasil. Revista Brasileira de Saúde Materno Infantil, Recife, v. 18, n. 3, p. 491-499, jul./set. 2018. Disponível em:

https://www.scielo.br/pdf/rbsmi/v18n3/pt_1519-3829-rbsmi-18-03-0481.pdf. Acesso em: 01 out. 2020. 


\section{Capítulo 4}

d.)

\section{ASSISTÊNCIA DE ENFERMAGEM NA AMAMENTAÇÃO EXCLUSIVA DURANTE O PUERPÉRIO IMEDIATO.}

Maria Caroline Soares de Souza

Eliana Amaro de Carvalho Caldeira

Raquel de Oliveira Martins Fernandes

Laércio Deleon de Melo

Leone Mendes Dias

Camila Cristina Gregório de Assis

Juliana de Lima Brandão

Yasmin Mendonça Campos

Joana Carvalho Barros

Josilene Sobreira Rodrigues
Enfermeira Graduada pelo Centro

Universitário Estácio de Juiz de Fora, Brasil.

Enfermeira. Doutoranda em Saúde Coletiva pela Universidade Federal de Juiz de Fora, Brasil.

Enfermeira. Mestre em Enfermagem pela Universidade Federal de Juiz de Fora, Brasil.

Enfermeiro. Doutorando em Enfermagem pela Universidade do Estado do Rio de Janeiro, Brasil.

Enfermeiro. Mestre em Enfermagem pela Universidade Federal de Juiz de Fora, Brasil.

Enfermeira. Mestranda em Enfermagem pela Universidade Federal de Juiz de Fora, Brasil.

Enfermeira. Doutoranda em Enfermagem pela Universidade do Estado do Rio de Janeiro, Brasil.

Acadêmica em Enfermagem. Centro

Universitário Estácio de Juiz de Fora, Brasil.

Acadêmica em Enfermagem. Centro

Universitário Estácio de Juiz de Fora, Brasil.

Acadêmica de Enfermagem pelo Centro

Universitário Estácio de Juiz de Fora, Brasil. 


\section{Resumo}

Introdução: o alimento ideal para o bebê é o leite materno, pois atua no sistema imunológico, evita infecções, doenças diarreicas, dentre outras doenças. Por isso é necessário que o aleitamento materno exclusivo ocorra até os seis meses de vida do bebê, e com alimentos completares de preferência até dois anos de idade. Objetivou-se identificar a importância do profissional enfermeiro no processo de aleitamento materno exclusivo. Metodologia: trata-se de uma construção de um estudo de caráter descritivo e exploratório através da revisão bibliográfica. Resultado: destacou-se a importância da realização do aleitamento materno através de ações de promoção em saúde, por parte do profissional enfermeiro tanto para a puérpera quanto para os familiares, enfatizando os benefícios do aleitamento para o crescimento e desenvolvimento do recém-nato. Conclusão: conclui-se que a importância do enfermeiro no procedimento do aleitamento materno é de alto valor, para que o procedimento possa ser realizado com qualidade desde as primeiras horas do puerpério.

Palavras Chaves: Enfermeiro; Aleitamento Materno; Período Pós-parto. 


\section{INTRODUÇÃO}

O aleitamento materno é de grande importância devido aos benefícios de ampliação do vínculo afetivo entre mãe e filho. A amamentação diminui a morbimortalidade infantil e ajuda no desenvolvimento do recém-nato. O mesmo contém um alto valor nutricional e proteção imunológica, por conter anticorpos como IgA secretora, lactoferrina e outros (FIALHO, LOPES, DIAS et al., 2014).

A saúde da mãe e do recém-nascido interfere no sucesso do aleitamento juntamente com o apoio ou não do profissional de saúde. Outros fatores também podem interferir como: fatores sociais, educacionais, culturais e familiares influenciam positivamente ou negativamente na continuidade da amamentação, por isso é necessário enfatizar a importância da amamentação exclusiva até o sexto mês de vida da criança e o aleitamento complementar até os dois anos de idade (SOUZA, 2014).

O Ministério da Saúde (2013), auxilia a amamentação até os dois anos de idade ou mais, e nos primeiros 6 meses o bebê receba somente leite materno exclusivamente. Pois quanto maior o tempo o bebê mamar no peito da mãe, melhor para a saúde de ambos.

Segundo Fialho, Lopes, Dias, et al. (2014), a média de duração do aleitamento exclusivo é menor que o mínimo recomendado pelo Ministério da Saúde, mesmo as mães reconhecendo a importância de amamentar. E mesmo a mulher querendo amamentar, para que essa prática seja realizada e mantida, esta mulher precisa conhecer os benefícios e a duração recomendada, necessário apoio e compreensão no meio de sua realidade sociocultural. Nesse pensamento, é imprescindível que a mulher tenha assistência em suas dúvidas e dificuldades, para que ela se sinta mais segura no papel de mãe e capacitada para o aleitamento de seu filho.

De acordo com Martins, Góes, Pereira, et al. (2018), as mães tem dúvidas sobre o aleitamento, dentre as dúvidas destacam-se como deve ser realizada, a duração, a exclusividade, o manejo prático, tempo entre as mamadas, a pega, a posição e cuidados com as mamas. O pré-natal é o momento para iniciar o preparo para a amamentação, não se esquecendo de que as orientações e o apoio deverão continuar também após o parto.

É importante na prática clínica da amamentação, que o enfermeiro tenha o conhecimento científico e técnico da anatomia e fisiologia da lactação e da sucção. Outros fatores também poderão interferir, como aspectos emocionais e psicológicos. O enfermeiro capacitado então deve orientar sobre o posicionamento e pega adequada, ensinando como fazer a extração manual do leite materno e outras 
maneiras de proporcionar o leito materno ao recém-nascido (RN), sem que seja por meio da mamadeira (AZEVEDO, ALVES, SOUZA, et al.,2015).

Nesse contexto, o estudo teve como objetivo identificar a importância do profissional enfermeiro no processo de aleitamento materno exclusivo.

\section{JUSTIFICATIVA}

Durante a graduação me foi despertado o interesse pelo tema e acho que mesmo nos dias atuais de altíssima relevância a continuidade do estudo deste tema, visto que ainda permeiam dificuldades do processo de amamentar durante o período de puerpério.

\section{METODOLOGIA}

Este artigo se desenvolveu a partir da construção de um estudo de caráter descritivo e exploratório através da revisão bibliográfica em: livros, manuais, artigos, revistas científicas, realizada na Biblioteca Virtual em Saúde (BVS), Scientific Eletronic Library Online (SciELO), e Biblioteca Virtual do Centro Universitário Estácio Juiz de Fora. A busca dos dados se deu entre Abril e Maio de 2019, em todas as bases foram utilizados as seguintes palavras chave: aleitamento materno, enfermeiro e puerpério. Para um melhor aproveitamento sobre o assunto apresentado foi realizado um fichamento para planejamento e organização do trabalho, sendo selecionado materiais com pertinência à temática em questão, artigos que discorressem sobre os objetivos desta pesquisa, além de possuírem todas as palavras chave em seu contexto. Optou-se pela inclusão somente de artigos em português cujas publicações fossem de caráter gratuito. Já como critério de exclusão, optou-se por desconsiderar relatos de caso, teses, dissertações, artigos em outros idiomas como inglês e espanhol, além de publicações realizadas anteriormente ao ano de 2013 e que não possuíssem relação com o tema.

\section{RESULTADOS}

Entende-se que há necessidade de investimento em estratégias educativas dialógicas para que o enfermeiro possa reconhecer as dificuldades e dúvidas maternas, assim atendendo as reais necessidades sobre o aleitamento, dando apoio e orientação adequada e com isso reduzindo o desmame precoce (MARTINS, GÓES, PEREIRA, et al., 2018).

Segundo Baptista, Alves, Souza (2015), o desmame precoce ocorre por conta do desconhecimento da mãe a respeito do benefício para o desenvolvimento saudável do recém-nato. 
A partir disso, a OMS E Fundo das Nações Unidas para a Infância (UNICEF) criaram a Instituto de Humanidades, Artes e Ciências (IHAC), que compõem os "Dez Passos para o Sucesso da Amamentação", para a promoção e também proteção da amamentação adequada. Citada abaixo:

Passo 1 - Ter uma política de aleitamento materno escrita que seja rotineiramente transmitida a toda equipe de cuidados de saúde;

Passo 2 - Capacitar toda a equipe de cuidados de saúde nas práticas necessárias para implementar esta política;

Passo 3 - Informar todas as gestantes sobre os benefícios e o manejo do aleitamento materno;

Passo 4 - Ajudar as mães a iniciar o aleitamento materno na primeira meia hora após o nascimento; conforme nova interpretação: colocar os bebês em contato pele a pele com suas mães, imediatamente após o parto, por pelo menos uma hora e orientar a mãe a identificar se o bebê mostra sinais de que está querendo ser amamentado, oferecendo ajuda se necessário;

Passo 5 - Mostrar às mães como amamentar e como manter a lactação mesmo se vierem a ser separadas dos filhos;

Passo 6 - Não oferecer a recém-nascidos bebida ou alimento que não seja o leite materno, a não ser que haja indicação médica e/ou de nutricionista;

Passo 7 - Praticar o alojamento conjunto - permitir que mães e recém-nascidos permaneçam juntos -24 horas por dia;

Passo 8 - Incentivar o aleitamento materno sob livre demanda;

Passo 9 - Não oferecer bicos artificiais ou chupetas a recém-nascidos e lactentes;

Passo 10 - Promover a formação de grupos de apoio à amamentação e encaminhar (BRASIL, 2019).

Segundo Baptista, Alves, Souza (2015), o terceiro quinto e décimo passo, enfatizam a importância das informações as gestantes/puérperas, referente os benefícios, estímulos e a manutenção do aleitamento materno, assim incentivando o aleitamento.

A qualidade da assistência, durante os períodos de gestação, o parto e no puerpério depende de uma qualificação e capacitação dos profissionais da enfermagem. Sem o conhecimento e orientação necessários por parte das mães a qualidade da amamentação torna-se prejudicada. Os pais e familiares devem estar cientes da importância do aleitamento materno, para o desenvolvimento adequado da criança. Assim, o enfermeiro capacitado, deverá orientar e apoiar para que o desmame não ocorra devido à falta de informação. Um dos fatores que influência o desmame precoce é a mãe trabalhar fora de casa. As mães acabam desmando pelas dificuldades encontradas, a falta de informação e falta de apoio no início da lactação (SOUZA, 2014). 
Para Guimarães, Bonelli, Conde, et al. (2018), a autoconfiança é um fator de extrema importância no momento da amamentação e pode interferir no sucesso do procedimento. Porém, há pouca utilização desse fator pelo enfermeiro, precisa-se que o enfermeiro esteja aberto para analisar condutas, conceitos e estratégias sobre o aleitamento materno.

De acordo com Fialho, Lopes, Dias, et al. (2014), a abordagem das gestantes, tem que se repensar para a promoção do aleitamento materno para que seja despertado o desejo de amamentar por até dois anos de idade. Essa promoção tem que ter oportunidades de aprender habilidades e práticas para enfatizar a importância do aleitamento materno com mais vigor e perseverança pelo enfermeiro em todos os níveis de atendimento, diminuindo os obstáculos iniciais.

O amamentar é influenciado por vários fatores culturais, sociais, emocionais, psíquicos e biológicos, e aos benefícios que lhe cabe é importante para o desenvolvimento e crescimento da criança. Devido a mudanças na fase do puerpério, o enfermeiro deve estar qualificado para identificar complicações possíveis e assim orientar e apoiar as mães nessas grandes mudanças (DUARTE et al., 2013).

Segundo Castro, Silva e Silva, (2015), os fatores sociodemográficos não interferem no conhecimento das mães sobre o aleitamento materno, e nem na promoção a saúde feita pelo enfermeiro. Mas, outros fatores como: estado civil, a escolaridade, a profissão, causam interferência na decisão de amamentar. Para a diminuição da morbidade e mortalidade infantil é importante medidas de promoção a saúde feita pelo enfermeiro no acolhimento mãe-bebê, na primeira semana do pós-parto.

De acordo com o Fialho, Lopes, Dias, et al., (2014), para o enfermeiro, é oportuno o contato com as mulheres no período do pré-natal, para a sensibilização sobre os benefícios do aleitamento materno. A qualificação do enfermeiro quanto ao seu conhecimento sobre o processo da amamentação poderá auxiliar a mulher a superar as dificuldades do aleitamento, adaptando suas práticas as circunstâncias sociodemográficas e epidemiológicas atuais, oferecendo apoio às mulheres em amamentar ou não seus filhos.

Segundo Duarte et al., (2013), o enfermeiro tem que respeitar a decisão da mãe de amamentar ou não, mas não esquecendo de promover a importância do aleitamento materno para a mãe e bebê. 0 vínculo durante o acolhimento ajuda o enfermeiro realizar estratégias para realizar a educação em saúde e promover o aleitamento materno de imediato, juntamente ao conhecimento científico e políticas de saúde existentes para o mesmo. 
Embora o conceito de aleitamento materno exclusivo e seus benefícios como ajudar no crescimento e desenvolvimento do recém-nato, proteção contra infecções, melhoramento do vínculo mãe-filho e baixo custo do alimento, mesmo assim uma parcela das mulheres ainda encontra dificuldades na prática de amamentação até os seis meses de vida, pois os profissionais de saúde somente enfatizam a teoria sobre o aleitamento materno (TELES et al., 2017).

Duarte et al. (2013), entende-se que o enfermeiro utiliza várias formas de promover o aleitamento materno no puerpério imediato, através do vínculo pelo acolhimento ou educação em saúde.

O Ministério da Saúde (2013), indica que o enfermeiro leve o recém-nato para puérpera iniciar o mais precocemente o aleitamento materno, pois este deve ter autonomia para auxiliar o procedimento. Essas estratégias não são limitadas somente no puerpério imediato, mas devem ser iniciadas no prénatal.

A Política Nacional de Humanização (PNH) - Humaniza SUS foi crida em 2003, enfatizando os princípios do SUS. A PNH deve estar presente e se adentrar em todas as políticas e programas do SUS, incentivando trocas altruístas entre gestores, trabalhadores e usuários (BRASIL, 2003).

A educação em saúde é uma atividade de importância, o enfermeiro passa as informações necessárias, assim torna o indivíduo mais independente possível dessa maneira torna-se responsável pela própria saúde. Porém, o papel que o profissional tem na prática da amamentação, é indispensável porque ajuda a prevenir problemas com as mamas, auxilia na posição correta do bebê ao mamar, orientando a mulher a relaxar e ser calma no momento de amamentar. Ajudando a superar as suas dificuldades inicias, com isso reduzindo a desistência de amamenta (BAPTISTA, ALVES, SOUZA, et al., 2013).

Assim como apontado por Azevedo et al., (2015), a pega incorreta acaba gerando estresse, e ocasionando uma mamada ineficaz, abalando a puérpera em continuar o aleitamento materno e aparecendo problemas mamários.

O enfermeiro tem que ter um olhar crítico, ao analisar a mãe e bebê no momento da amamentação. O enfermeiro tem que avaliar a forma adequada de posicionamento e pega, que são: o rosto do bebê de frente para a mama, com nariz na altura do mamilo; o corpo do bebê próximo ao da mãe; o bebê com cabeça e tronco alinhados; o bebê bem apoiado; mais aréola visível acima da boca do bebê; boca bem aberta; o lábio inferior virado para fora; o queixo tocando a mama (BRASIL, 2015). 
É necessário que o enfermeiro tenha eficiência em se comunicar, para ajudar a mãe a tomar decisões, também escutá-la e compreendê-la. Assim, conversar sobre os benefícios e malefícios das opções para que se sinta apoiada e acolhida, sobretudo, desenvolvendo a confiança no enfermeiro (BRASIL, 2015).

Para ajudar no ato da amamentação deve-se proporcionar um local tranquilo e confortável. A estratégia mais utilizada pelos enfermeiros é a comunicação verbal, no manejo clínico. O profissional tem que saber articular, ouvir, compreender, transmitir a informação, e deixar que decida o que é melhor para ela e seu filho (AZEVEDO et al., 2015).

Nesse contexto, o Ministério da Saúde (2015), visa que a comunicação não-verbal como gestos, expressão facial, sorrir, como sinal de acolhimento; balançar a cabeça afirmativamente, como sinal de interesse; tocar na mulher ou no bebê, quando apropriado, como sinal de empatia; ajuda a comunicação entre profissional e puérpera.

Portanto, o enfermeiro torna-se um colaborador do ato de amamentar para a puérpera, lhe dando empoderamento na prática de amamentação. Por meio de orientação e aconselhamento, diminuiu os problemas mamários e o desmame precoce. Necessitando também, enfatizar a importância da amamentação para a saúde da mulher, criança e família (PEREIRA et al., 2019).

Em um artigo publicado por Rocha et al. (2018), o estudo revelou que as mulheres da família têm grande influência na construção do entendimento sobre o aleitamento materno. Torna-se de grande necessidade a criação de estratégias educativas em saúde, com o apoio e inclusão da família para o aumento da continuidade do aleitamento materno. Sugere-se que dentro das estratégias tenham diferentes aspectos para que sejam de interesse das mulheres e suas famílias.

\section{CONSIDERAÇÕES FINAIS}

O enfermeiro deve estar preparado para prevenir, reconhecer e resolver os problemas na relação puérpera e recém-nato, em especial a amamentação. Por isso, é necessário ter uma visão atenta para as necessidades da puérpera, durante o aleitamento, para que essas necessidades sejam precocemente identificadas e resolvidas e intervir junto a puérpera para que seja capaz de realizar a amamentação adequada ao recém-nato.

O papel fundamental do enfermeiro é proporcionar qualidade na assistência durante o aleitamento materno, porém é necessário que o enfermeiro amplie sua competência técnica e habilidades para oferecer sucesso na hora da amamentação e também reduzir agravos à saúde da puérpera e recém- 
nato. Assim, em sua prática profissional, os enfermeiros atuam como colaborador do aleitamento materno, apoiando e promovendo a amamentação exclusiva.

O enfermeiro é um facilitador na prática de amamentar, pois visa por meio de aconselhamento e orientação, favorecer o aleitamento materno. Ajudando no momento da pega e posição, para que não aconteçam prejuízos para mãe e recém natos. Além disso, o enfermeiro deve ter uma comunicação verbal e não verbal, para ajudar no procedimento e vínculo afetivo mãe-bebê.

Os familiares e demais pessoas em contato com a puérpera, são considerados fatores importantes para o início e a continuidade do aleitamento materno, a mulher se sentirá mais autoconfiante e segura durante a prática da amamentação, junto ao enfermeiro. Assim reduzindo o desmame precoce, a morbidade e mortalidade infantil. 


\section{REFERÊNCIAS}

AZEVEDO, A.R.R.; ALVES, V.H.; SOUZA, R.M.P., et al. O manejo clínico da amamentação: saberes dos enfermeiros. Escola Anna Nery Revista de Enfermagem. Rio de Janeiro, v.19, n.3, p.439-445, Jul/Set 2015. Disponível em : http://pesquisa.bvsalud.org/portal/resource/pt/lil-761619. Acesso:12 Abr. 2019.

BAPTISTA, S.S.; ALVES, V.H.; SOUZA, R.M.P., et al. Manejo clínico da amamentação: atuação do enfermeiro na unidade de terapia intensiva neonatal. Rev Enferm UFSM. Rio de Janeiro. v.5, n.1, p.2331. Jan/Mar. 2015. Disponível em: https://periodicos.ufsm.br/index.php/reufsm/article/view/14687. Acesso em:01 Mai. 2019.

BAPTISTA, S.S.; ALVES, V.H.; SOUZA, R.M.P., et al. Lactação em mulheres com bebês prematuros: reconstruindo a assistência de enfermagem. Revista de Pesquisa Cuidado é fundamental. care. Online, Rio de Janeiro,v.6, n.3, p.1036-1046. Jul./Set. 2013. Disponível em:

http://pesquisa.bvsalud.org/portal/resource/pt/lil-719748. Acesso em:30 Abr. 2019.

BRASIL. Ministério da Saúde. Saúde da Criança: Aleitamento Materno. 2019. Disponível em: http://portalms.saude.gov.br/saude-de-a-z/crianca\#aleitamento.

Acesso em:12 Mai. 2019.

BRASIL. Ministério da Saúde. Iniciativa Hospital Amigo da Criança (IHAC). Brasília: Ministério da Saúde, 2017. Disponível em: http://portalms.saude.gov.br/artigos/41186-iniciativa-hospital-amigo-dacrianca-ihac. Acesso em:12 Mai. 2019.

BRASIL. Ministério da Saúde. Secretaria de Atenção à Saúde. Departamento de Atenção Básica. Saúde da criança : aleitamento materno e alimentação complementar / Ministério da Saúde, Secretaria de Atenção à Saúde, Departamento de Atenção Básica. Brasília, 2015. Disponível em:

http://bvsms.saude.gov.br/bvs/publicacoes/saude_crianca_aleitamento_materno_cab23.pdf. Acesso em:12 Mai. 2019.

BRASIL. Ministério da Saúde. Política Nacional de Humanização. Brasília, 2013. Disponível em: http://portalms.saude.gov.br/acoes-e-programas/humanizasus. Acesso em:12 Mai. 2019.

CASTRO, R.J.S.; SILVA, B.E.M.; SILVA, D. Percepção das mães sobre as práticas dos enfermeiros na promoção do aleitamento materno.Rev. Enf. Portugal. v.5, n.6, set. 2015. Disponível em:

http://www.scielo.mec.pt/scielo.php?script=sci_arttext\&pid=S0874-02832015000600008. Acesso em: 25 Abr. 2019.

DUARTE, E..F.; SANTO, C.S.E.; COUTO, M.G.C., et al. Estratégias utilizadas por enfermeiros na promoção do aleitamento materno no puerpério imediato. Rev.Cuidarte. Rio de Janeiro, V.4, N.1, P.523-530. Jul.2013. Disponível em:

http://pesquisa.bvsalud.org/portal/resource/pt/lil-752166. Acesso em: 10 Mai. 2019. 
FIALHO,F.A.; LOPES, A.M.;DIAS, I.M.A.V., et al. Fatores associados ao desmame precoce do aleitamento materno.Revista Cuidarte, Minas Gerais.v.5,n.1,p.670-678, Abr.2014.Disponível em :http://pesquisa.bvsalud.org/portal/resource/pt/bde-27389. Acesso em: 18 Abr. 2019.

GUIMARÃES, C.M.S.; BONELLI, M.C.P.; Conde, R.G., et al. A autoeficácia na amamentação e na prática profissional do enfermeiro. Rev enferm UFPE on line.Recife, v.12, n.4, p.1085-1090, Abr. 2018.

Disponível em: http://pesquisa.bvsalud.org/portal/resource/pt/biblio-970724. Acesso em :05 Abr. 2019.

MARTINS, D.P.; GÓES, F.G.B.; PEREIRA, F.M.V., et al.Conhecimento de nutrizes sobre aleitamento materno: contribuições da enfermagem. Rev.Enferm. UFPE on line. Recife,v.12, n.7, p.1870-1878, Jul.2018.

Disponível em:http://pesquisa.bvsalud.org/portal/resource/pt/biblio-986543. Acesso:10 Abr. 2019.

PEREIRA, R.M.; ALVES, V.H.; RODRIGUES, D.P., et al. O conhecimento do enfermeiro acerca do manejo clínico da amamentação: saberes e práticas. Rev Fun Care Online. Rio de Janeiro,v.11, n.1, p.80-87, Jan/Mar.2019.Disponível em: http://pesquisa.bvsalud.org/portal/resource/pt/biblio-968598. Acesso:12 Abr. 2019.

ROCHA, A.L.A.; GÓES, F.G.B.; PEREIRA, F.M.V., et al. O processo de ensino-aprendizagem de puérperas nutrizes sobre aleitamento materno. Rev Cuidarte. Rio de Janeiro, v.9, n.2, p.2165-76 , Fev/Abr.2018. Disponível em:

https://revistacuidarte.udes.edu.co/index.php/cuidarte/article/view/510. Acesso em:28 Abr. 2019.

SOUZA, B.A.P.Assistência de enfermagem no incentivo do aleitamento materno no município de Ipaba: Um relato de experiência.Trabalho de Conclusão de Curso ( Curso de Especialização em Atenção Saúde da Família). Universidade Federal de Minas Gerais. Minas Gerais, 2014.

Disponível em:http://pesquisa.bvsalud.org/portal/resource/pt/una-5565. Acesso em: 15 Mai. 2019.

TELES M.A.B.;JUNIOR, R.F.S.; JÚNIOR, G.G.S., et al.Conhecimento e práticas de aleitamento materno de usuárias da estratégia saúde da família.Rev enferm UFPE on line. Recife,v.11, n.6, p.2302-2308 , Jun.2017.

Disponível em: http://pesquisa.bvsalud.org/portal/resource/pt/bde-32156.Acesso em:30 Abr. 2019. 


\section{Capítulo 5}

\section{d. \\ O PAPEL DA ENFERMAGEM NO CUIDADO PALIATIVO A CRIANÇA COM LEUCEMIA}

Jessica Aline Raimundo

Mariana de Carvalho Oliveira

Rosemeire da Silva Pereira Gouveia

Tairene Maria Pereira Gomes

Eliana Amaro de Carvalho Caldeira

Raquel de Oliveira Martins Fernandes

Laércio Deleon de Melo

Leone Mendes Dias

Camila Cristina Gregório de Assis

Joana Carvalho Barros
Enfermeira Graduada pelo Centro

Universitário Estácio de Juiz de Fora, Brasil.

Enfermeira Graduada pelo Centro

Universitário Estácio de Juiz de Fora, Brasil.

Enfermeira Graduada pelo Centro

Universitário Estácio de Juiz de Fora, Brasil

Enfermeira Graduada pelo Centro

Universitário Estácio de Juiz de Fora, Brasil

Enfermeira. Doutoranda em Saúde Coletiva pela Universidade Federal de Juiz de Fora, Brasil.

Enfermeira. Mestre em Enfermagem pela Universidade Federal de Juiz de Fora, Brasil.

Enfermeiro. Doutorando em Enfermagem pela Universidade do Estado do Rio de Janeiro, Brasil.

Enfermeiro. Mestre em Enfermagem pela Universidade Federal de Juiz de Fora, Brasil.

Enfermeira. Mestranda em Enfermagem pela Universidade Federal de Juiz de Fora, Brasil.

Acadêmica em Enfermagem. Centro

Universitário Estácio de Juiz de Fora, Brasil. 


\section{Resumo}

Introdução: em uma característica específica e acadêmica, esta pesquisa tem por objetivo geral identificar qual é a fundamentação dos cuidados paliativos na atuação da enfermagem, bem como elucidar as dificuldades encontradas pela enfermagem. E, em análise, os recursos e benefícios que podem ser oferecidos às crianças portadoras de leucemia como tratamento e possibilidade de um bem-estar psicológico e físico. A metodologia foi de natureza qualitativa, através da revisão bibliográfica. Foi realizada no período entre os dias 16 e 24 de maio de 2020, utilizando artigos de língua portuguesa e estrangeira (inglês) disponíveis na base de dados SciELO. Desenvolvimento: o cuidado paliativo infantil compreende diversos fatores, aspectos e elementos que vão de encontro com a razão e essência do ser humano. Os sentimentos são ainda mais fortes no qual o profissional precisa estar preparado, no qual o profissional precisa estar preparado para trabalhar nesta área da saúde. Um destes eventos se refere à uma criança em situação de terminalidade, no qual não há mais recursos medicamentosos, e inicia-se o processo dos cuidados paliativos. Considerações Finais: compreende o cuidar para promover a qualidade de vida dos pacientes e dos familiares, de modo a minimizar o sofrimento em doenças graves que podem limitar as condições físicas dos pacientes, como também a condição psicossocial e espiritual. A partir do momento em que o diagnóstico é definido torna-se necessário que o paciente possa estar sendo cuidado nos mais diferentes processos e recursos, seja pelo sistema governamental, do sistema Único de Saúde, ou pelas unidades responsáveis.

Palavras-chave: Cuidados Paliativos, enfermeiro, contexto e recursos em saúde. 


\section{INTRODUÇÃO}

O câncer está relacionado a um número bem significativo de doenças caracterizadas por um crescimento desordenado de células que age nos tecidos e órgãos. É um grande problema de saúde pública vivenciado de forma intensa no sistema de saúde brasileiro, no qual se observa uma condição epidemiológica específica que envolve os aspectos sociais e econômicos. Os fatores que podem estar relacionados aos inúmeros casos acometidos no contexto da saúde têm apresentado um perfil diferenciado no tratamento e nos resultados. Isso pode ser caracterizado pelo aumento de exposição a fatores cancerígenos, como hereditários, familiares e étnicos, por envelhecimento do indivíduo e com a perspectiva de novas ferramentas tecnológicas para diagnosticar (INCA, 2014).

No contexto da saúde infantil, se torna um desafio ter um diagnóstico preciso, pois muitas vezes não é definido de imediato. Isso por que no câncer infantil as vezes pode estar relacionado com fatores ambientais, mas em outras vezes corresponde aos fatores nas malignidades infantis, o que dificulta e prejudica um diagnóstico mais rápido. Desta forma a criança ao procurar um centro de saúde específico já chega com a doença em estágio avançado, e, de certa forma pode estar relacionado a outros fatores como a falta de conhecimento e de informações correta e precisas aos pais (INCA, 2018).

Existem vários tipos de câncer, entre eles está a leucemia. A leucemia é uma doença que se manifesta através dos glóbulos brancos no qual se caracteriza por apresentar células deficientes na medula óssea do indivíduo substituindo as células normais. A célula presente na corrente sanguínea pode sofrer modificações antes de se tornar uma célula adulta e se transforma m uma célula cancerosa. São mais de 12 tipos de leucemia e entre elas se destaca quatro de setor primário que são: leucemia mieloide aguda (LMA), leucemia mieloide crônica (LMC), leucemia linfocítica aguda (LLA) e a leucemia linfocítica crônica (CLL) (MANCINI, 2020)

A Leucemia Linfoide Aguda (LLA), é uma doença maligna resultante de sucessivos defeitos genéticos de células progenitoras da linhagem linfoide e da proliferação clonal destas células precursoras anormais na medula óssea tendo sua origem nas células leucêmicas denominadas linfoblastos que substituem as células normais do sangue através do bloqueio da produção de glóbulos vermelhos, brancos e plaquetas (INCA, 2014, pág. 44).

Sendo o tipo de câncer infantil mais comum a LLA, constitui em torno de um terço de todas as neoplasias malignas da criança (GURNEY, 1995). A leucemia infantil tem como fator de ocorrência a deficiência dos glóbulos brancos responsáveis pela defesa do organismo da criança. Origina-se nas células-tronco no qual ela se modifica de forma rápida e ataca as demais células do organismo. A 
leucemia linfóide aguda é em decorrência de que as células afetadas são as células jovens denominadas linfóides. $O$ autor complementa que o quadro clínico da doença é complexo, a leucemia infantil representa 28\% dos cânceres em pessoas de 0 a 19 anos, e, que a maioria dos casos ocorridos nesta faixa etária compreende a leucemia linfóide aguda (LLA), com uma porcentagem de $75 \%$ dos casos. A leucemia infantil apesar de grave vem apresentando resultados positivos com relação ao tratamento nos últimos anos, no qual $90 \%$ das crianças que apresentaram a doença e que acompanharam um tratamento adequado tiveram sucesso e se recuperaram de forma satisfatória. Isso devido ao fato de que há um diferencial entre a doença da LLA em crianças e em adultos ao desenvolvimento das células cancerosas (MANCINI, 2020).

Embora existam diferenças nos esquemas terapêuticos de um centro para outro, o tratamento é sempre prolongado chegando a variar de dois a três anos. Os protocolos modernos são constituídos de cinco grandes fases: indução da remissão, intensificação, consolidação, reindução, prevenção da leucemia no sistema nervoso central (SNC) e continuação ou manutenção da remissão (PEDROSA, 2002).

De acordo com estudos de Silva et al. (2020), a leucemia infantil nos últimos anos vem apresentando uma queda nos resultados de mortes de crianças diagnosticadas com leucemia. No entanto, este índice ainda é preocupante, pois o que se observa é que em países mais desenvolvidos a taxa é menor. Ou seja, o fator agravante no contexto brasileiro para que as crianças tenham mais êxito em seus tratamentos adequados contra a doença está a condição sócio econômica. Assim, em 100\% de crianças diagnosticadas cerca de, 85 a 90\% atualmente se recuperam, e, 15 a 20\% vão a óbito (PEDROSA, 2002). O autor Lima (2011), destaca que muitas pessoas não recebem durante o processo da morte uma assistência adequada, o que nos leva a refletir quanto a necessidade da ampliação da cobertura desses serviços além da produção e divulgação de conhecimento específicos nesta temática sendo vital para melhorias das práticas em cuidados paliativos.

Para a Organização Mundial de Saúde, os cuidados paliativos são medidas que aumentam a possibilidade de se minimizar o sofrimento dos pacientes e seus familiares que enfrentam doença terminal, mediante a prevenção e alívio do sofrimento, por meio de identificação precoce, avaliação correta e tratamento da dor e de outros problemas físicos, psicossociais e espirituais (GENOVA, 2002).

O cuidado paliativo é uma abordagem que promove a qualidade de morte de pacientes e de suas famílias diante de doenças graves e que ameaçam a vida, objetivando a prevenção e o alívio do sofrimento pela dor ou de outros problemas físicos, psicossociais e espirituais. A abordagem paliativa 
busca manter a dignidade do paciente no final da vida e dar suporte à família na doença e no luto (OMS, 2007). O paciente é quem vivencia a necessidade do cuidado paliativo e, portanto, necessita de profissionais que estejam junto a ele e a sua família e que possuam experiência para ajudá-lo a enfrentar esse momento (KRUSE, 2007).

O cuidar fundamenta-se "na troca de sentimentos e experiências que necessita ter, por parte dos envolvidos, confiança, empatia e respeito" (Sales, 2008). Em pediatria, os cuidados paliativos "devem atender às necessidades biopsicossociais das crianças, garantindo dignidade, qualidade de vida, morte digna e preservação da sua autonomia. O profissional de saúde envolvido no cuidado é visto como ponto de apoio no enfrentamento da doença pela família e criança" (SILVA, 2015).

Portanto diante de todo o processo de cuidar e mesmo diante de um tratamento adequado da leucemia infantil, por vezes o cuidar da enfermagem no contexto dos cuidados paliativos precisa ser realizado. Esse tratamento deverá ser em todos os níveis de prevenção de quadros álgicos e desconforto e durante o tratamento, no qual o enfermeiro tem capacidade de atuar de forma multidisciplinar em hospitais, na saúde comunitária, ambulatorial, cirúrgica e na maioria das vezes em atendimento quimioterápico. Os cuidados paliativos pela enfermagem constituem-se em uma modalidade de atenção à saúde que vem ao encontro de diferentes realidades, para minimizar o sofrimento causado pelas doenças e pelas intervenções tecnológicas (GENOVA, 2002).

O enfermeiro envolvido no cuidado paliativo torna-se um ponto de apoio à família e ao paciente. Desta forma, toda a equipe de saúde tem papel fundamental nos cuidados a serem realizados, o enfermeiro deve desenvolver uma assistência integral por meio de uma escuta atenta e a comunicação efetiva, objetivando diminuir a ansiedade, na aceitação do diagnóstico, auxiliando o convívio com a enfermidade, o medo da família e da criança, frente ao prognóstico futuro (COSTA, 2010).

Desta forma, os enfermeiros que cuidam de crianças em cuidados paliativos, sentem-se às vezes inseguros e despreparados para comunicar as más notícias, além de enfrentarem dificuldades para manejar as crianças no final da vida e dificuldade de viver o luto. Devido a falta de treinamento para lidar com os familiares, o desgaste físico e emocional, a falta de educação continuada e a necessidade de inclusão do tema na formação profissional.

A presente reflexão " ancora-se em aspectos substantivos que representam o assistir em enfermagem, conforme os Diagnósticos de Enfermagem (DE), da NANDA-I, e as Intervenções de Enfermagem (IE), à luz da Classificação das Intervenções de Enfermagem (NIC, sigla do inglês" NursingInterventionsClassification) (BULECHEK, 2016). 
Em 2017, o Conselho Federal de Enfermagem (Cofen) atualizou o Código de Ética dos Profissionais de Enfermagem (CEPE). Definiu-se, então, que a enfermagem "organiza suas ações e intervenções de modo autônomo ou em colaboração com outros profissionais da área" (COFEN, 2017).

Considera-se que o enfermeiro e sua equipe abordam as necessidades de saúde, no que compete à enfermagem. Porém, em uma só perspectiva de cuidado disciplinar seria insuficiente quando considerado o ser humano em sua integridade, o que, por si só, convida os diversos saberes ao diálogo (SECRETÁRIA DE SAÚDE, 2017).

Com base em todo o contexto, nas dificuldades encontradas pelo sistema de saúde em atender a esta modalidade de cuidados, e a dificuldade do profissional com relação aos cuidados necessários, tem essa pesquisa como objetivo identificar a fundamentação dos cuidados paliativos na atuação da enfermagem, bem como elucidar as dificuldades encontradas pela enfermagem. E, em sequência, colocar em análise os recursos e benefícios que podem ser oferecidos às crianças portadoras de leucemia como tratamento e possibilidade de um bem estar psicológico e físico.

A prática colaborativa considera o "cuidado compartilhado entre profissionais de equipes de saúde que realizam o trabalho de forma integrada, interprofissional, com articulação das ações, dos saberes técnico científico e com objetivos comuns voltados às necessidades dos usuários" (SECRETÁRIA DE SAÚDE, 2017).

Isso remete ao campo profissional da saúde a ideia de que os cuidados paliativos precisam ser bem mais embasados cientificamente de modo a proporcionar um preparo da equipe de enfermeiros de forma segura, bem como promover uma sobrevida aos pacientes em casos de patologia grave considerando sua diversidade, condição e nível da doença.

O percurso metodológico adotado nesta pesquisa foi de natureza qualitativa, através da revisão bibliográfica sobre o papel do enfermeiro frente aos cuidados paliativos em crianças com leucemia. A pesquisa foi realizada no período entre os dias 16 e 24 de maio de 2020, utilizando artigos de língua portuguesa e estrangeira (inglês) disponíveis na base de dados Scientific Eletronic Libray (SciELO). A exploração não procura contar ou mensurar os artigos, ela serve para alcançar informações caracterizadas que manifestam os sentidos dos acontecimentos. Para que fosse possível construir um referencial teórico, foi adotada uma pesquisa descritiva, analítica e fundamental em várias fontes de pesquisa acumuladas na literatura publicada sobre o tema (GALVÃO et al, 2019). 
Como critérios de inclusão foram considerados os artigos que atenderam as propostas e objetivos desta pesquisa, tendo como ênfase os cuidados paliativos em crianças. Os critérios de exclusão destinaram-se: publicações e revisões de leitura que não respondiam ao propósito do assunto. Foram utilizados os seguintes descritores: Cuidados paliativos, papel do enfermeiro, leucemia, assistência de enfermagem e criança em oncologia.

O papel do enfermeiro ao longo dos anos vem ganhando uma condição específica nas ações no contexto da saúde cada vez mais amplo. Os cuidados e assistência a pacientes em diversos casos patológicos tem chamado a atenção de vários estudiosos. O que requer para estes profissionais estudos, capacitação e conscientização. Para tanto há um grande olhar para os pacientes com doenças graves, como o câncer por exemplo.

\section{DESENVOLVIMENTO}

O estudo descreve a respeito dos cuidados paliativos em oncologia pediátrica, onde a assistência desses cuidados deve abranger a solidariedade e o respeito dos profissionais às vontades e anseios da criança e seus familiares ou responsáveis legais; com isso a opinião sobre o plano de cuidados nessa fase do tratamento pode estabelecer as suas preferências em relação ao melhor método e abordagem no tratamento da patologia

\subsection{CUIDADOS PALIATIVOS INFANTIL: FUNDAMENTAÇÃO E CONTEXTO}

De uma visão ampla e específica os cuidados paliativos se fundamentaram a partir de iniciativas pessoais para promover o bem-estar do paciente. Esta iniciativa partiu de Cicely Mary StrodeSaunders, em 1967, que em suas funções de assistente social, enfermeira e médica, que contribuiu diretamente para a nova maneira de cuidar de pacientes que se encontram em fase terminal e em condições paliativas próximas ao óbito. Esta nova maneira de cuidar conspirou para uma compreensão em relação às principais necessidades do indivíduo, do paciente, mesmo que em suas limitações, proporcionando-o minimizar o seu sofrimento em todos os sentidos e aspectos. Os cuidados paliativos representam uma forma diferenciada no cuidar com relação aos pacientes em fase terminal, no qual o profissional enfermeiro tem a necessidade de se utilizar estratégias adequadas, com segurança e como essencial nas ações, a comunicação constante entre o paciente e o enfermeiro (RABELLO, 2010).

A enfermagem sem dúvida exerce um papel fundamental na vida destes pacientes. $O$ enfermeiro precisa ter um olhar mais humano, pois, o paciente passa a ter preocupações com sua nova condição de vida, de um ser saudável para uma pessoa que passa a necessitar de cuidados mais específicos, e, 
que o mesmo está ainda se inteirando da doença que o acomete, no qual o paciente não consegue ver condição de melhora ou recuperação, evidenciando o pior, até mesmo a morte. O medo de não conseguir a cura necessária faz com que o paciente fique mais frágil. O papel do enfermeiro vai basear em oferecer apoio e suporte para estes. E, esse apoio e suporte somente são possíveis a partir de um método sistematizado da assistência da enfermagem (SAE), no qual é possível fazer uma avaliação concisão de cada paciente (SANTOS; ROCHA; BERARADINELLI, 2011).

Importante e fundamental para os cuidados paliativos, é a relação humana, de modo a estabelecer a confiança e a consistência na maneira de ser cada sujeito, enfermeiro e paciente, no qual as perspectivas de cada um tenha seu direcionamento necessário realizado, que é o fator diagnóstico e terapêutico, identificando os principais processos de assistência e promover o reconhecimento eo vínculo afetivo dos enfermeiros com pacientes, consolidando as ações e atitudes que vão envolver sentimentos e cumplicidade em todos os momentos de vida do paciente com a família do paciente (CRISTIANI, 2013).

Em diferentes ações, os profissionais enfermeiros precisam criar novos métodos de gerenciar as ações e os problemas operacionais do dia a dia, de forma a aprimorar as competências necessárias, as habilidades, liderança e resolutividade de toda essa situação que possa dificultar todo o trabalho do profissional enfermeiro e de sua equipe de uma forma geral. Para propor uma atuação gesticuladora diferenciada para as dificuldades que vão surgindo, necessário três elementos fundamentais: criatividade, improviso, diálogo e orientação dos chefes ( ALVES et al 2014).

O cuidado paliativo infantil compreende diversos fatores, aspectos e elementos que vão de encontro com a razão e essência do ser humano. Os sentimentos são ainda mais fortes no qual o profissional precisa estar preparado para trabalhar nesta área da saúde, na qual ele vai enfrentar eventos muito difíceis e tristes. Um destes eventos se refere à uma criança em situação de terminalidade, no qual não há mais recursos medicamentosos, curativos e inicia-se então o processo dos cuidados paliativos. Há neste caso a busca por uma visão diferenciada no qual se deve estabelecer uma mudança de paradigmas com relação à fase terminal de vida do indivíduo, de modo a apresentar uma característica mais humana, com respeito tanto ao paciente, à família e também ao profissional que se envolve através do cuidar (NASCIMENTO et al, 2013).

Os cuidados paliativos apresentam em seu contexto expressões e momentos de dor que influenciam direta e indiretamente a todos que ali fazem parte. É uma abordagem que busca promover a qualidade de vida do paciente e da família em situações de doenças degenerativas graves e que coloca em risco 
a vida do indivíduo, ou seja, do paciente. Tem como objetivo imediato prevenir o alívio da dor, dos desconfortos físicos, do sofrimento e de problemas que possam vir a surgir mediante a situação que são psicossociais e espirituais. Busca promover a qualidade de vida do paciente no final da vida, dandoIhe atenção e suporte necessário para o enfrentamento da dor e da perda, quando o paciente venha a óbito (COSTA, 2010)

$\mathrm{O}$ agir aos cuidados paliativos requer ações em conjunto, em equipe, no qual todos devem ter a consciência de que a assistência precisa ser autêntica e eficiente para que se possam buscar melhores condições de vida ao paciente, de forma digna e no qual o mesmo possa se expressar sem medo. A expressão "cuidados paliativos" compreende uma equipe de grande proporção compondo entre médicos, enfermeiros, técnicos de enfermagem, psicólogos e demais profissionais que atuam em conjunto acolhendo e possibilitando ao paciente e à família bem-estar e um ambiente mais seguro (SILVA, 2015).

Torna-se, portanto que haja uma reflexão sobre a relação entre o profissional enfermeiro e o paciente para que realmente o cuidado possa ser realmente fundamentado e consolidado nas principais ações para que o paciente possa se sentir bem e disposto a enfrentar o tratamento da melhor forma possível.

\subsection{DESAFIOS E DIFICULDADES NA PRÁTICA DO PROFISSIONAL ENFERMEIRO AOS CUIDADOS}

\section{PALIATIVOS EM CRIANÇAS.}

Quando se fala em cuidados paliativos se verifica a importância dos profissionais da área da saúde, bem como dos cuidadores familiares que fazem a diferença na vida destes pacientes. Compreende estes a força, a esperança e a ajuda de que tanto precisam para buscar a cura e vencer os obstáculos das doenças que possam vir e causar sérios danos à saúde dos mesmos.

Neste sentido as ações, as práticas dos cuidados paliativos emanam principalmente para os profissionais da saúde cuidados e atenção, uma vez que há certo limite nas ações e nas práticas com relação aos cuidados de modo a torná-los mais acolhedor e mais humano. (CASARIN \& GORAYEB, 2012).

As ações da equipe de enfermagem compreendem desde o início, a partir da identificação do diagnóstico em conjunto com o cuidado curativo e se estende até durar o tratamento no qual este profissional vai gerenciar o controle da dor e de todos os diferentes sintomas que se possam a apresentar (RABELLO, 2017). 
Outra questão muito discutida também nos estudos sobre este tema estão os desafios que os profissionais encontraram durante a atuação em cuidar de crianças com leucemia, pois além da capacitação está também o preparo psicológico em relação às diversas situações vividas neste contexto. Não é, com certeza, uma tarefa fácil, pois os profissionais precisam estar preparados para enfrentar a perda de uma vida que teria ainda muitos anos a serem vividos (CRISTIANI, 2013).

Entre os desafios profissionais, no cuidar paliativo em crianças com leucemia ou outra doença grave, constitui a condição de trazer aos profissionais enfermeiros medos e inseguranças devido ao fato de ter que lidar diretamente com a perda de uma vida infantil, causando-Ihes angústias e dor junto à família que os mesmos acolhem sendo o mediador de toda a situação vivida durante o processo de tratamento (SILVA, 2015).

O cuidado paliativo compreende o cuidar para promover a qualidade de vida dos pacientes e dos familiares, de modo a minimizar o sofrimento em doenças graves que podem limitar as condições físicas dos pacientes, como também as condições psicossociais e espirituais, quando se trata de um quadro que pode chegar a óbito. E, assim, visa os cuidados paliativos e as ações da enfermagem contribuir para que o paciente e sua família possam ter os cuidados necessários dentro das condições dignas para um ser humano, dando suporte básico à família ao enfrentamento da dor do luto (SALES, 2008).

Para a realização das ações para promover os cuidados paliativos, torna-se necessário um trabalho em equipe para que os desafios possam ser enfrentados e trazer resultados satisfatórios para a recuperação do paciente e a abordagem paliativa realizada. Os "cuidados paliativos" se constitui com a formação de uma equipe multiprofissional, composta por médicos, enfermeiros, técnicos de enfermagem, psicólogos e outros profissionais que ali se encontram. Profissionais estes que buscam atuar no objetivo interdisciplinar a fim de articular ações que venham realmente promover a qualidade de vida do paciente e de sua família. (LIMA, 2011) Diante de todo o processo que se refere ao cuidar paliativo pediátrico, há o envolvimento de sentimentos e troca de experiências, e, constitui-se também a presença e necessidade de confiança e respeito entre ambos, favorecendo a relação à continuidade do tratamento. É um trabalho em equipe, no qual cada profissional vem complementar as ações e assim atender as necessidades reais dos pacientes (LIMA, 2011).

Em frente a todo o contexto do cuidar paliativo em crianças com leucemia, muitos são os desafios que os profissionais da enfermagem enfrentam em seu dia a dia de modo a executar suas ações e ir aprendendo com as dificuldades. Porém muitos profissionais ao serem abordados com relação às 
ações se sentem inseguros, pois acham que nos cursos acadêmicos não se dão ênfase necessário aos cuidados paliativos com crianças. Para eles, se torna importante que se crie uma disciplina específica para capacitar e acompanhar as principais demandas epidemiológicas da sociedade e casos clínicos graves, como leucemia, e outras doenças relacionadas às crianças quando pacientes. $E$, o único assunto abordado é como cuidados paliativos, é sobre o fator oncológico, mas de uma forma geral, e não em específico em crianças (SILVA, 2015).

Portanto, as dificuldades dos profissionais enfermeiros estão também relacionadas com a formação acadêmica, no qual muitos conteúdos e situações vividas em unidades hospitalares ficam sem ser colocadas em estudo e em reflexão.

\subsection{RECURSOS E BENEFÍCIOS CONCEDIDOS PELAS INSTITUIÇÕES AOS CUIDADOS PALIATIVOS EM} CRIANÇAS COM LEUCEMIA.

Os cuidados paliativos são ações que envolvem vários fatores e estruturas nas unidades hospitalares, como recursos tecnológicos, medicamentosos e profissionais capacitados. $E$, tudo isso gera um custo para as unidades hospitalares. E, esse fator é ainda mais complexo quando se trata de pacientes com leucemia e em crianças. Há, portanto, aqui cuidados e fatores que são avaliados o tempo todo em todos os setores hospitalares para que o tratamento possa ser o melhor possível, por isso que, muitas vezes as unidades são diferenciadas e preparadas para exercer a atividade com segurança e condições específicas necessárias para atuarem (SALES, 2008).

Quando se fala em cuidados paliativos se verifica a importância dos profissionais da área da saúde, bem como dos cuidadores familiares que fazem a diferença na vida destes pacientes. Compreende estes a força, a esperança e a ajuda de que tanto precisam para buscar a cura e vencer os obstáculos das doenças que possam a vir a causar sérios danos à saúde dos mesmos. $E$, todo esse processo envolve os demais profissionais, como psicólogo e agente social para que tenham condições para o enfrentamento e as experiências que vão ser vividas e sentidas (CRISTOFANI, 2012).

Neste sentido as ações, as práticas dos cuidados paliativos emanam principalmente para os profissionais da saúde cuidados e atenção, uma vez que há certo limite nas ações e nas práticas com relação aos cuidados de modo a torná-los mais acolhedor e mais humano. (CASARIN \& GORAYEB, 2012).

As ações da equipe de enfermagem compreendem desde o início, a partir da identificação do diagnóstico em conjunto com o cuidado curativo e se estende até durar o tratamento no qual este 
profissional vai gerenciar o controle da dor e de todos os diferentes sintomas que se possam a apresentar (NANDA,2018).

Os recursos oferecidos aos pacientes em casos clínicos graves, como os cuidados paliativos em crianças com leucemia é um assunto de grande importância para a área da saúde, pois trata da busca de preservar e promover a vida de crianças nas quais podem ainda ter possibilidades de cura e obter quem sabe uma sobrevida. A partir do momento em que o diagnóstico é definido torna-se necessário que o paciente possa estar sendo cuidado nos mais diferentes processos e recursos, seja pelo sistema governamental, do sistema Único de Saúde, ou pelas unidades responsáveis. No entanto é sabido que muitas vezes os recursos são escassos e faltam medicamentos e aparelhos que podem prolongar a vida do paciente com qualidade (NANDA, 2018).

A tecnologia é um recurso de grande importância e corresponde a um investimento de extrema necessidade ao tratamento. Pois compreende a condição de minimizar a dor e a qualidade de vida, proporcionando a cura de um quadro clínico degenerativo. Há, portanto, ainda reflexão sobre a condição de que a tecnologia pode ser uma aliada ao tratamento como também pode aumentar o momento de sofrimento do paciente, prolongando assim o quadro que às vezes não vai se restabelecer, e, desta forma fica o paciente e familiar com momentos ainda mais difíceis e tensos (RABELLO, 2010).

A utilização das novas tecnologias no contexto hospitalar tem alcançado resultados muito importantes. Elas podem ser classificadas em leve, leve-dura e dura. Compreende uma análise de todo o processo produtivo, até o produto final. Assim, as tecnologias leves correspondem às relações; as leve-duras aos saberes estruturais, e teorias, e, as tecnologias duras são os recursos materiais (MERHY et al 2006).

As tecnologias em saúde compreendem os recursos de grande importância para auxiliar o profissional enfermeiro quanto às decisões a serem tomadas, como articular as principais ações no contexto do cuidar, adequando da melhor forma possível, tempo e espaço e com relação ao ambiente no qual o paciente está inserido, buscando atender ao paciente com recursos mais inovados e assim promover o cuidar com resultados mais satisfatórios (GRABOIS, 2009).

Assim as tecnologias, dura, leve-dura e leve são as principais ferramentas envolvidas no trabalho do enfermeiro, no cuidar em saúde. Entre as três, a leve-dura está diretamente relacionada às relações do cuidar. São saberes estruturados, que se contextualiza na clínica médica, psicanalítica, epidemiologia, no taylorismo e fayolismo. E, a dura é a mais específica com relação ao maquinário, 
pois compreende a mesma a utilização de equipamentos tecnológicos que são as máquinas, as normas específicas operacionais e de certa forma a organização de toda as ações em busca de melhores resultados (FERRI et al, 2007).

De acordo com a Organização Mundial de Saúde os cuidados paliativos é uma necessidade que deve ser incluída como fator integral à saúde, nas diversas doenças crônicas e, com ênfase em idosos. É um documento que visa a formação educacional das equipes dos profissionais e da população buscando apresentar os princípios e os benefícios dos cuidados paliativos (LIMA, 2011)

Nos últimos anos os Cuidados Paliativos vêm em busca de uma consolidação mais ampla e de forma que o respeito e o acolhimento sejam cada vez mais humanos. Neste sentido O Manual de Cuidados Paliativos (2009) da Academia Nacional de Cuidados Paliativos, trouxe algumas nomenclaturas nova para minimizar determinadas expressões que em determinados momentos que não favorecem à qualidade de vida os pacientes de forma digna (INCA, 2012)

Os benefícios e ações necessárias aos cuidados paliativos de uma forma geral é estabelecida de acordo com cada caso e assim compreendendo um fluxo assistencial que obedece a termos de cuidados dentro destas assistências e o encaminhamento dentro das necessidades de atendimento no sistema de saúde, e, de acordo com as intervenções e evoluções que possam ser apresentadas (BULECHEK, 2016).

Dentro das normas e dispositivos legais estabelecidos por leis e sistemas governamentais em vigor através de suas portarias e ministeriais, os cuidados paliativos possui implementações em políticas públicas e programas que visam organizar e controlar as linhas de cuidados dentro das modalidades de atendimento, em um modelo assistencial único que busque recursos e venha garantir os serviços de tratamento necessários. Entre os cuidados de controle do câncer, como recursos se apresentam: o diagnóstico, o tratamento, a reabilitação e os cuidados paliativos. São ações previstas e disponíveis nos setores de gestão do Sistema Único de Saúde (SUS), estabelecidos e centralizados em diversos departamentos de saúde, para facilitar a integração destas ações de forma ampla e próxima do paciente. $E$, neste direcionamento buscar também ações que possam possibilitar a reabilitação do paciente e de responsabilidade dos profissionais da equipe, como por exemplo, a equipe de enfermagem (INCA, 2012). 


\section{CONSIDERAÇÕES FINAIS}

Nas análises estudadas, verificaram-se efeitos satisfatórios acerca de assistência de enfermagem a crianças portadoras de enfermidade oncológica, sendo que no Brasil são poucas as explorações baseadas em sinais referentes à assistência focada nos cuidados paliativos infantis. O estudo descreve a respeito dos cuidados paliativos em oncologia pediátrica, onde a assistência desses cuidados deve abranger a solidariedade e o respeito dos profissionais, as vontades e anseios da criança e seus familiares ou responsáveis legais; com isso a opinião sobre o plano de cuidados nessa fase do tratamento pode estabelecer as suas preferências em relação ao melhor método e abordagem no tratamento da patologia.

Viabilizar as melhores condições nos cuidados paliativos compreende profissionalismo, humanismo e uma estrutura hospitalar adequada. Importante os estudos para que os recursos sejam sempre colocados em evidência e de certa forma sempre ser avaliados para que os desafios possam ser apresentados e assim preparar os profissionais de acordo com a realidade vivida. Atuar como profissional enfermeiro em cuidados paliativos requer conhecimento e uma estrutura psicológica que possa impulsionar as ações de forma subjetiva e, ao mesmo tempo, propor uma atuação humanizada.

Necessário um trabalho em equipe, pois, o apoio às decisões e ações emergentes que precisam ser tomadas é que vão abrir maiores possibilidades no atendimento e com resultados satisfatórios, cooperando assim para minimizar o sofrimento dos pacientes. As ações compreendem o saber decidir, pois quando se fala em criança o cuidado é ainda mais expressivo, pois a mesma está em formação pessoal e cognitiva, no qual qualquer evento ou situação desagradável pode piorar ainda o quadro clínico. Importante cautela, disposição e incentivo para que a mesma possa vencer os desafios do tratamento e sentir-se acolhida.

Outro ponto muito importante que destacou neste estudo foi a importância da comunicação entre o paciente e o profissional enfermeiro e a família do paciente. Uma comunicação clara, espontânea de forma a colaborar com o desenvolvimento do tratamento e propor às crianças um ambiente seguro e dentro das necessidades de cada um., obedecendo os direcionamentos éticos e humanos. Assim, para completar as ações do cuidar de forma a buscar estratégias mais inovadoras, o profissional enfermeiro conta com as tecnologias, as quais vêm estruturar as ações dentro de outras normas e condutas que necessário ao profissional enfermeiro conhecimentos e organização específica em saúde. Necessário que o mesmo também saiba adequar cada uma delas de acordo com as necessidades dos pacientes, principalmente em pacientes que inspiram cuidados mais complexos e mais estruturados. 


\section{REFERÊNCIAS}

Alves A. K. C.,Azevedo C. A. S.;Branco T. B.;Silva M. V. R. S. S.; Miranda R. H. S.Moura y. G.; Farias, G. B. S.; Guimarães, J. T. F. Desafios vivenciados por enfermeiros no ambiente hospitalar. REAS, Revista Eletrônica Acervo Saúde, 2017. Vol. Sup. 7, S494-S501. Eletrônica Acervo Saúde/ Electronic Journal Collection Health ISSN 2178-2091.

Bulechek GM, Butcher HK, Dochterman JM. Classificação das intervenções de enfermagem. 6. ed. Rio de Janeiro: Mosby/Elsevier; 2016. Disponível em:

https://www.scielo.br/scielo.php?script=sci_arttext\&pid=S141481452020000300501\&lang=pt\#B001

Costa TF, Ceolim MF. A enfermagem nos cuidados paliativos à criança e adolescente com câncer: revisão integrativa da literatura. Revista Gaúcha de Enfer, 2010. 31(4):776-784. Disponível em: https://www.scielo.br/pdf/csc/v18n9/v18n9a27.pdf

Cristofani, L M . (2012) . Leucemia linfoide aguda. In: V. Odone Filho, P T. Maluf Jr., L. M. Cristofani, M. T. A. Almeida, \& R. A. P. Teixeira (Eds.). Doenças neoplásicas da criança e do adolescente (pp. 3-18). Barueri, SP: Manole. Disponível em:

https://www.scielo.br/scielo.php?pid=S010279722015000300565\&script=sci_arttext\&tIng=pt\#B06

Ferri, SMN, PEREIRA, JB, Mishima SM, Guimarães MC, Caccia-Bava, Almeida MCP. As tecnologias leves como geradoras de satisfação em usuários de uma unidade de saúde da família* [ Acesso em maio de 2021] Disponível em: https://www.scielosp.org/article/icse/2007.v11n23/515-529/. Favor colocar a data de 2007 conforme citação no texto assim comoa revista, vol, número etc...conforme ABNT

Galvão MCB, RicartilLM.Revisão sistemática da literatura: conceituação, produção e publicação. LOGEION: Filosofia da informação, Rio de Janeiro, v. 6 n. 1, p.57-73, set.2019/fev. 2020 DOI: https://doi.org/10.21728/logeion.2019v6n1.p57-73.

Gurney JG, Severson RK, Davis S, Robison LL. Incidenceofcancer in children in the United States. Sexrace, and 1-year age-specific rates byhistologictype. Cancer 1995; 75: 2186-95. Disponível em: https://www.scielo.br/pdf/rbsmi/v2n1/v2n1a10.pdf

Instituto Nacional de Câncer (INCA). ABC do câncer: Abordagem básica para o controle do câncer. 2 ed. Rio de Janeiro: INCA; 2012. Disponível em

https://www.scielo.br/scielo.php?script=sci_arttext\&pid=S141381232017021003321\#: :text=0\%20c \%C3\%A2ncer\%20h\%C3\%A1\%20quatro\%20d\%C3\%A9cadas, poucos\%20ou\%20m\%C3\%A9dios\%20recu rsos1.

Instituto Nacional do Câncer. (2014). Estimativa 2014: Incidência de câncer no Brasil. Rio de Janeiro, RJ: Autor. Disponível em:

https://www.scielo.br/scielo.php?pid=S010279722015000300565\&script=sci_arttext\&tlng=pt\#B06

Instituto Nacional do Câncer. (2018). Causas e prevenção. O que causa o câncer? BRASIL, Ministério da Saúde. Disponível em: https://www.inca.gov.br/causas-e-prevencao/o-que-causa-cancer. 
Kruse MHL. Cuidados paliativos: uma experiência. Rev HCPA 2007; 27(2):69-73. Disponível em: https://www.scielo.br/pdf/csc/v18n9/v18n9a27.pdf

Lima, Regina. Cuidados paliativos: desafios dos sistemas de saúde. SCIELO, 2011. Disponível em: https://www.scielo.br/pdf/rlae/v19n2/pt_01.pdf

Mancini N.Leucemia infantil: tratamentos e seus avanços. [ Acesso em abbril de 2021] Disponível em: https://revista.abrale.org.br/leucemia-infantil-tratamento/.

Merhy EE, Chakkour M, Stéfano E, Stéfano ME, Santos CM, Rodrigues RA. Em busca de ferramentas analisadoras das tecnologias em saúde: a informação e o dia a dia de um serviço, interrogando e gerindo trabalho em saúde. In: Merhy EE, Onocko R, organizadores. Agir em saúde: um desafio para o público. São Paulo: Hucitec; 2006. p. 113-150.Disponívlel em:

https://www.scielo.br/scielo.php?script=sci_nlinks\&ref=000139\&pid=S1413-

$8123200900080002600006 \&$ lng=en.

NANDA International. Diagnósticos de enfermagem da NANDA-I: definições e classificação 2018-2020. 11. ed. Porto Alegre: Artmed; 2018. Disponível em:

https://www.scielo.br/scielo.php?script=sci_arttext\&pid=S141481452020000300501\&lang=pt\#B001

Nascimento DM et al. Experiência em cuidados paliativos à criança portadora de leucemia: a visão dos profissionais.Ciência\& Saúde Coletiva, 18(9):2721-2728, 2013

Organização Mundial de Saúde (OMS). Medicina paliativa: cuidados e medicamentos. 2007. [acessado 2021 mai 5]. Disponível em: http://www.who. int/cancer/palliative/en/. Disponível em: https://www.scielo.br/pdf/csc/v18n9/v18n9a27.pdf

Pedrosa, Francisco. Leucemia linfóide aguda: uma doença curável. SCIELO, 2002. DISPONÍVEL EM: https://www.scielo.br/pdf/rbsmi/v2n1/v2n1a10.pdf

Rabello CAFG, Rodrigues PHA. Saúde da Família e cuidados paliativos infantis: ouvindo os familiares de crianças dependentes de tecnologia. Ciênc Saúde Col. 2010;15(2):379-88. Disponível em: https://www.scielo.br/pdf/rlae/v19n2/pt_01.pdf

COFEN- CONSELHO FEDERAL DE ENFERMAGEM - Resolução no 564, de 6 de novembro de 2017 (BR). Aprova o novo Código de Ética dos Profissionais de Enfermagem. Diário Oficial da União [periódico na internet], Brasília (DF), 6 dez 2017 [citado 10 nov 2019]. Disponível em:

https://www.scielo.br/scielo.php?script=sci_arttext\&pid=S141481452020000300501\&lang=pt\#B001

Sales CA, Silva MRB, Borgognoni K, Rorato C, Oliveira WT. Cuidado paliativo: a arte de estar-com-ooutro de uma forma autêntica. Rev. enferm. UERJ. 2008,16(2):174-179. Disponível em: https://www.scielo.br/scielo.php?script=sci_arttext\&pid=S1413-81232013000900027

Santos I. D.; Rocha R. D. P. F.; Beraradinelli , L. M. M. Necessidades de orientação de enfermagem para o autocuidado de clientes em terapia de hemodiálise. REBEn: Revista Brasileira de Enfermagem, v. 64, n. 2, p. 335-342, Març-Abril 2011. [Acesso em: 04 jun. 2021].Disponível em: http://www.scielo.br/pdf/reben/v64n2/a18v64n2.pdf. 
Silva AF, Issi HB, Motta MGC, Bonete DZA. Palliativecare in paediatriconcology: perceptions, expertise andpracticesfromthe perspective ofthemultidisciplinaryteam. Rev Gaúcha Enferm. 2015 [cited 2016 Jun 8];36(2):56-62. Disponível em: https://www.scielo.br/scielo.php?script=sci_arttext\&pid=S198314472017000100408 